\title{
WORLD ECONOMIC TRENDS: AN ENQUIRY
}

\author{
AKHILESH CHANDRA PRABHAKAR \\ School of Economic, Finance and Baking \\ Universiti Utara Malaysia
}

\begin{abstract}
The series of current global economic and financial crises especially in the USA and the European Stock Exchange Markets, the international division of labour and the global distribution of economic and political power led by free markets economies clearly indicate the collapse of Adam Smith's ideology, and the Thatcher-Reagan free-market model that dominated thinking for 30 years has been discredited. A practical solution for the current ills is possible.
\end{abstract}

Keywords: International finance capital, crisis of capitalism, socialism is the future.

\section{Introduction}

The global financial crisis, which was ignited by the subprime mortgage crisis in the United States, has rapidly spread a world-wide problem, from developed countries to newly emerging markets and developing countries, and from the financial industry to the real economy, and the scope, depth and impact are unprecedented. International financial markets have been experiencing great fluctuations and the financial systems of the US and Europe have been performing extremely poorly and experiencing shortages in liquidity. Some newly emerging markets and developing countries have been suffering from large capital outflows, causing serious worsening of their economies. Protectionism is again emerging worldwide, intensifying international competition and friction in the areas of trade, capital and technology. The more direct cause was the inappropriate macroeconomic policies of developed capitalist countries, over-expansion of the virtual economy and ineffective government regulation in addition to a pattern of long-term consumption on credit that could not be sustained.

The crisis has revealed the intrinsic shortcomings of an absolutely free market economy, deep-rooted structural problems in economic globalization and serious defects of the irrational international 
economic order and the international financial system in particular. The crisis has grown into a profound global economic recession, further revealing the damage caused by the theory and practice of neo-liberalism characterized by privatization, mercerization and liberalization. ${ }^{1}$

Most economists believe that recessions are caused by inadequate aggregate demand in the economy, and favour the use of expansionary macroeconomic policy during recessions. Strategies favoured for moving an economy out of a recession vary depending on which economic school the policymakers follow. Monetarists would favour the use of the expansionary monetary policy, while Keynesian economists may advocate increased government spending to spark economic growth. Supply-side economists may suggest tax cuts to promote business capital investment. When interest rates reach the boundary of an interest rate of zero per cent conventional monetary policy can no longer be used and the government must use other measures to stimulate recovery. Keynesians argue that fiscal policy, tax cuts or increased government spending will work when monetary policy fails. Spending is more effective because of its larger multiplier but tax cuts take effect faster. ${ }^{2}$ Some recessions have been anticipated by stock market declines. In Stocks for the Long Run, Siegel mentions that since 1948, ten recessions were preceded by a stock market decline, by a lead time of 0 to 13 months (average 5.7 months), while ten stock market declines of greater than 10 per cent in the DJIA were not followed by a recession. The real estate market also usually weakens before a recession. However real-estate declines can last much longer than recessions. Since the business cycle is very hard to predict, Siegel argues that it is not possible to take advantage of economic cycles for timing investments. Even the National Bureau of Economic Research (NBER) takes a few months to determine if a peak or trough has occurred in the US. ${ }^{3}$

During an economic decline, high yield stocks such as fast moving consumer goods, pharmaceuticals, and tobacco tend to hold up better. However when the economy starts to recover and the bottom of the market has passed (sometimes identified on charts as a MACD), growth stocks tend to recover faster. There is significant disagreement about how health care and utilities tend to recover. Diversifying one's portfolio into international stocks may provide some safety; however, economies that are closely correlated with that of the U.S. may also be affected by a recession in the U.S. There is a view termed the halfway rule according to which investors start discounting an economic 
recovery about halfway through a recession. In the 16 U.S. recessions since 1919, the average length has been 13 months, although the recent recessions have been shorter. Thus, if the 2008 recession followed the average, the downturn in the stock market would have bottomed around November 2008. The actual US stock market bottom of the 2008 recession was in March 2009.

\section{Impacts of Recessions on Employment and Social Life}

The living standards of people dependent on wages and salaries are more affected by recessions than those who rely on fixed incomes or welfare benefits. The loss of a job is known to have a negative impact on the stability of families, and individuals' health and well-being. Research shows that low-skilled, low-educated workers and the young are most vulnerable to unemployment in a downturn.

The IMF estimates that global recessions seem to occur over a cycle lasting between 8 and 10 years. During what the IMF terms the past three global recessions of the last three decades, global per capita output growth was zero or negative. More than 1.14 billion people were estimated in $2011^{4}$ to be living below the international poverty line of 1.25 dollars a day. Close to two million children could die in the next five years if the crisis persists. Some of the poorest nations in the world (especially those in Sub-Saharan Africa) seem to have been left behind and marginalized by globalization, and they are poorer today (i.e., their average real per capita income is lower today) than they were two or three decades ago.

The World Bank president Robert Joylaki warns in the meeting of G-20 that "due to unemployment problems, high petroleum prices, inflation especially increased price hike in food items, the current global economic crisis, and the Middle-east and North African political crisis could push 100 million people more into extreme poverty worldwide in 2011." ${ }^{6}$

After recessions in Britain in the 1980s and 1990s, it took five years for unemployment to fall back to its original levels. Youth are almost three times as likely to be unemployed, and although they make up only 24.7 per cent of the total working-age population, youth make up as much as 40.2 per cent of the world's total unemployed.

In fact, between 1997 and 2007, the number of unemployed youth rose from 63 million to 71 million, an increase of 13.6 per cent according to the ILO. The global number of unemployed in 2008 is estimated at 190 
million, out of which 109 million are men and 81 million are women and the global unemployment rate increased from 5.7 per cent in 2007 to 6.0 per cent in 2008 .

Continued labour-market deterioration in 2009 may lead to an estimated increase in global unemployment of 39 million to 61 million workers relative to 2007, according to the International Labour Organisation. The worldwide ranks of the unemployed may range from 210 million to 241 million- the highest number on record. Unemployment problems increased at 10.2 per cent not only in the USA (the Ministry of Labour of USA said, more than 70, 60,000 people lost their jobs in December, 2007; it reached 1,50,00,000 in September, 2009; only 2, 63,000 people lost their jobs in September, 2009; and 85,000 people lost their jobs in December 2009) but it also increased 10 per cent in the European countries. All 16 European countries have already announced that the unemployment rate increased 10 per cent in 2009-2010. However, the Obama government trying to create more job opportunities, has announced a 30 trillion dollars' government budget for 2010 which is almost a 15.7 trillion dollar of budget deficit (which removed many previous social welfare schemes).

Meanwhile, global growth in real wages, which slowed dramatically in 2008, is expected to show even further in 2010, despite signs of a possible economic recovery. In a sample of 53 countries for which data are available, medium growth in real average wages had declined from 4.3pc in 2007 to 1.4pc in 2008. The World Bank warns that the current economic crisis could push 90 million people more into extreme poverty worldwide by end of 2010, adding to the 1.4 billion people estimated in 2005 to be living below the international poverty line of 1.25 dollars a day. Close to two million children could die in the next five years if the crisis persists. Some of the poorest nations in the world (especially those in Sub-Saharan Africa) seem to have been left behind and marginalized by globalization.

The cause of the problem was located in the fundamental defect of the free market system regarding its capacity to distinguish between "enterprise" and "speculation" and hence, in its tendency to become dominated by speculators, interested not in the long-term yield assets but only in the short-term appreciation in asset values. The crisis was not the result of some "mistakes" or "aberrations". It was just a failure of the system.

Finance capital led advanced economy today is under pressure. All signs point to 2012 witnessing an acceleration of the negative 
economic and fiscal metrics that plagued advanced and major emerging economies in 2011. In particular, the Eurozone debt crisis, which dramatically worsened in 2011, shows no sign of abating in 2012.

In fact, there is now a clear consensus among economists that the Eurozone has entered a double-dip recession in 2012. Nations such as Greece, Ireland, Spain and Portugal are currently in a recession so deep, it meets the definition of a full-blown economic depression. In Greece, unemployment ratio has increased from 21 per cent to 54 per cent. Thus, an unprecedented reduction in the total size of the American workforce is twisted into a lowering of the unemployment rate. But such gimmicks will probably become totally inoperative, once the impact of the looming Eurozone recession and banking crisis migrates to American shores.

The massive transfer of private debt into public debt by sovereigns as a synchronized response to the global financial and economic crisis unleashed in 2008 by the collapse of Lehman Brothers, failed to resolve the crisis, and it laid the seeds for an even more virulent global economic crisis by 2012. With a global sovereign debt crisis now an established reality and the Eurozone teetering while America has had its previous AAA credit rating downgraded by at least one major ratings agency, neither a continuation of failed policies nor gimmickry by politicians and central banks brought an end to the global economic crisis in 2012.

One of the most important rich-club's members like Japan's trade deficit surged to a record high in January 2012. Japan has been hurt by a slowdown in its key export markets such as the US and the Eurozone. Instead of a return to economic growth, the most optimistic forecast one could make is stagnation which, at a time of structural mega-deficits and ballooning national debts, is a guarantee of further long-term economic misery for a great many of the planet's inhabitants. There is considerable uncertainty in global financial markets. Asset and commodity prices, risk spreads, capital flows and exchange rates are highly susceptible to sudden strikes with devastating consequences for growth and employment.

Until the financial crisis, the credit, consumption and property bubbles in the USA generated a highly favourable global economic environment for developing economy in trade and investment, capital flows and commodity prices. At least one-third of the pre- 
crisis growth in China was due to exports, mostly to the USA, and the ratio was even higher for smaller Asian export-led economies. China's accession to the WTO also gave a major impetus to outsourcing and exports by removing uncertainties surrounding its access to the US market.

From the early years of the 2000s, low interest rates and rapid expansion of liquidity in the US, Europe and Japan triggered a boom in capital flows to developing countries. This was supplemented by a surge in workers' remittances, which exceeded 3 per cent of GDP in India and reached double-digit figures in some smaller developing countries. Commodity prices rose strongly, largely thanks to rapid growth in China. On some estimates, Latin America would not have seen much growth had terms-of-trade, dollar interest rates and capital flows remained at the levels of the late 1990s.

With the financial crisis the global economic environment deteriorated in all areas that had previously supported expansion in developing countries. However, developing economy showed resilience and was able to rebound quickly, particularly where a strong countercyclical response was made possible by favourable payments, reserves and fiscal positions built up during the preceding expansion. As a result, the growth impulse in some emerging Southern economies has shifted to domestic demand, including countries which had previously been export-led.

China has played a key role in the recovery of the South. It launched a massive stimulus package in infrastructure and property investment. Because of its high commodity intensity, this investment-led growth has given an even stronger boost to commodity prices than the precrisis export-led growth.

At the same time, short-term, speculative capital inflows surged with sharp cuts in interest rates and quantitative easing in advanced economy in response to the crisis. These have been more than sufficient to meet the growing deficits in several major developing countries including India, Brazil, Turkey and South Africa. But they have also widened deficits by leading to currency appreciations. This rapid domestic demand-led growth has now come to an end. China cannot maintain investment-led growth indefinitely. But it also faces hurdles in shifting rapidly to consumption-led growth. Even a moderate slowdown in China, towards 7 per cent, could bring an end 
to the boom in a broad range of commodities. This can be aggravated by a rapid exit of investors and traders in commodity derivatives as happened in 2008 after the collapse of the Lehman Brothers.

Developing economy also faces significant downside risks from advanced countries, including dampened export prospects and unstable capital flows. As noted by the IMF "even absent another European crisis, most advanced economies still face major breaks on growth. And the risk of another crisis is still very much present and could well affect both advanced and emerging economies."

This study focuses on economic systems and 'sustainable economic development problems' which are responsible for the financial and ultimately full-flagged economic crisis. As Keynes says (1934), “Our analysis shows... that long-run development is not inherent in the capitalist economy. Thus, "specific development factors" are required to sustain a long-run upward movement. The fact is that mature capitalist economies tend towards stagnation because workers are alienated from production activities."

\section{Objectives}

This research investigates the global economic trends and performance. One of its purposes is to serve as a point of reference for discussions on economic, social and related issues. Why does affluence coexist with dire poverty not only across different continents but also within the same country or even the same city? Can traditional, low-productivity subsistence societies be transformed into modern, high-productivity, high-income nations? To what extent are the development aspirations of the poor nations helped or hindered by the economic activities of rich nations? These and many other questions concerning international and national differences in standards of living, in areas including health and nutrition, education, employment, and life expectancies, might be posed on the basis of even this very superficial look at life around the world.

\section{Methodology}

This study, based on critical analysis, sheds some light on what is really happening at the country level, and goes beyond vulnerability studies or global forecasts. We need to continue to monitor the effects of the crisis to stimulate the policy responses that are needed 
as a matter of urgency-policy responses that have not, to date, been forthcoming. Both developing and developed countries need to build their resilience to economic shocks and ask themselves whether growth and development strategies, economic policies and institutions need a complete rethink in these turbulent times.

\section{Hypothesis}

Capitalism has neither the capacity, nor the morality, nor the ethics to solve the problems of poverty, unemployment, inequality, malnutrition and inflation. How China, replacing the G-7 in the wake of the economic crisis, through sharing their own science and technology to improve and transform agriculture and industrial sectors in Africa, Latin America, and Asia; through using FDI/ investment all over the world; willing to buy the USA and the EU Governments' debts; through creating a huge production networks of SMEs (approximately 42 million SMEs), and willing to compete all over the world, emerged as a 'new business leader'?

\section{An Overview of the Global Economy}

The economists, politicians, researchers, scientists and social activists now agreed that it is not only a financial crisis but a fullflagged global economic depression,' which is deeper than the great depression of the 1930s, and the recession it triggered is by far the most widespread and costly since the great depression. Around the world, it cost tens of millions of workers their jobs. In the United States, millions of families lost their homes and their wealth. To stem the crisis, governments and central banks took aggressive and, in many ways, unprecedented actions. In the autumn of 2008, we came closer to such a financial meltdown than at any time since the 1930s. Two big issues have dominated headlines in recent times: sovereign debt problems in the two biggest economic groupings, the United States and the European Union. To a dispassionate observer, it can be a source of wonder that what began as a crisis generated by the irresponsible excesses of financial markets has ended up as a problem of debt sustainability for the very governments that were forced to step in and clear up the mess. But this is an old story, for in history almost every financial crisis has been followed by a crisis of public debt because the crisis itself causes governments to spend more in bailouts as well as in reviving the economy during the subsequent recession. 
The difference is that this time the outcry against public "profligacy" and the attacks by bond markets against what are pronounced to be "unsustainable" levels of government debt began well before the global economy was out of the woods. As a result, everywhere the clarion cry was for fiscal austerity and reductions in government expenditure. This was so even though employment had not really recovered from the Great Recession in most major economies.

In the earlier episode, the collapse of the banking system led to the Great Depression. In the recent crisis, some of the world's largest financial institutions failed. Key markets stopped functioning. Credit dried up, even for healthy borrowers. As a result, vibrant companies that relied on short-term loans to pay their employees and buy materials faced potential ruin. Even some fundamental ways that we make payments for goods and services were threatened. Gasping for air in this financial crisis, the global economy since 2007 sank into the deepest, broadest, and longest downturn since World War II. Around the world, tens of millions of people lost their jobs. It is not only the advanced capitalist countries but almost all the capitalist nations who had been integrated or depending on the USA and the EU's markets; faced serious economic and political challenges. This prolonged crisis indicated the unsustainability of international finance capital-led, "oil Texas', and 'military-industrial complex' capital-intensive 'mode of production' in the US, and heavy dependence on 'financial sectors' led by Euro money-lending agency in the EU. Globalization had failed.

The World Bank has slashed its growth forecasts, and is now predicting a $0.3 \%$ contraction for the Eurozone in 2012, as the ensuing global downturn is likely to be deeper and longer-lasting than the great recession of the 1930s. Advanced capitalist countries do not have the fiscal and monetary space to stimulate the global economy. "Developing countries need to evaluate their vulnerabilities and prepare for further shocks, while there is still time," said World Bank chief, economist Justin Yifu Lin. In a veiled attack on Europe's austerity policies the bank said "it is not yet clear whether there is an end in sight to the vicious circle whereby budget cuts to restore debt sustainability reduce growth and revenues to the detriment of debt sustainability."

Despite the premature euphoria about the supposedly 'V-shaped' recovery, the world economy, in fact, has not really recovered from the 2008 Great Recession, and some fundamental contradictions still 
remained. Output growth in Japan had already turned negative once again in the most recent quarters, while it was sluggish in the US and likely to become much worse in the euro area given the inability to resolve the internal problems of the Eurozone. Part of the problem is that unless private expectations are 'managed' better by decisive government policies, negative expectations will become self-fulfilling. But it is harder for governments to 'manage expectations', because private investors themselves are schizophrenic about government deficits and economic growth.

Financial markets effectively appear to demand fiscal consolidation by putting very high spreads on the bonds of governments with high ratios of public debt to GDP or fiscal deficit to GDP. And then investors in these markets are very surprised (and react adversely) when attempts at fiscal austerity reduce economic activity and growth prospects. Global finance has been biting the hands of the governments that fed it so generously during the crisis, but in the process it is creating further problems both for itself and for the real economy. This is of major concern not just in itself, but also because even the period of recovery was not associated with much improvement in labour market conditions.

The unemployment rates there are historically high and citizens are already feeling the pinch in terms of reduced public services and higher user charges. Most striking of all, the strategy of cutting public expenditure will inevitably have a depressing effect on aggregate demand and therefore lower the chances of a real recovery, especially of employment and the indicators that matter to most people. In the three major advanced economic regions of the US, Europe and Japan, open unemployment rates increased during the Great Recession and since then have remained at these high levels despite subsequent increases in incomes and economic activity. In many emerging markets for which data are available, unemployment rates fell in 2010 but since then have started rising again. A September 2011 report from the ILO (International Labour Organization) to the G20 found that in the first quarter of 2011, only a handful of countries (notably, Argentina, Brazil, Turkey and Indonesia) had absolute employment levels that were above the levels of the first quarter of 2008, before the eruption of the global crisis. In some countries both output and employment were still below their earlier levels (including the developed world: European Union, the US and Japan) while in others like South Africa, output had recovered but employment was still lower than in early 2008. 
So, the weakening prospects for the world economy come at a time when labour-market conditions are already very fragile across the world. The strategy of fiscal consolidation and austerity in deficit countries has already created a self-reinforcing cycle of contraction in the Eurozone, which is currently the most fragile part of the global economy. As long as European leaders (and the IMF) continue to press for fiscal austerity, this will not just continue but get worse to the point where the current structure of the monetary union is no longer tenable. The much-vaunted move towards greater fiscal integration, expressed in the latest EU summit in December, is still based on forcing counterproductive tight fiscal rules on member countries, which is a really bizarre thing to do in the midst of economic contraction, and can only make the situation worse. The belief currently expressed by many economic commentators, that a 'big bazooka' in the form of even looser monetary policy of the European Central Bank, will be sufficient to lift economic activity, is unwarranted. So, it is not surprising that the vast majority of economists interviewed in a recent poll did not expect the Eurozone in its current form to survive the coming year.

Meanwhile the process of its deterioration and possible disintegration will have fearsome effects on the rest of the world. Already, declining demand from Europe has affected manufacturing exports from developing Asia both directly and indirectly. It is foolhardy to hope that economic expansion in China, Brazil, Russia and some other countries will be enough to compensate for the slowdown in the advanced economies. In sheer quantitative terms, total incomes and import demand in these countries simply cannot counterbalance the falling net demand from the US and Europe.

Now, the Head of the Macro Economics of the World Bank says "The motor of the global economy - developing countries - is slower at the same time as the world's largest economic area - the EU - is in recession and these could feed each other." Mahathir Mohamed, the prime minister of Malaysia for 22 long years from 1981 - years of reform in South Asia-invokes a Malaysian saying (similar wisdom can be found in almost all civilizations) which means that when you lose your way, go back to the beginning and start again. ${ }^{8}$ Global capitalism is, however, obdurate in not learning from such wisdom. Instead, the neo-liberal prescriptions advocate the imposition of austerity. This, as we have seen in these columns in the past, will only aggravate the situation and further accentuate the crisis. After spending billions of dollars to bail out the banks and financial institutions which were 
responsible for perpetuating the crisis, the governments in the United States and Europe have pursued austerity measures and cutbacks in public spending to shift the burden on to the people.

World trade also was slowing sharply, with growth seen at only 4.7 per cent for this year compared with an estimated 6.6 per cent in 2011. It also noted that oil supplies could be disrupted amid potential political tensions in the Middle East and North Africa. High deficits and debts in the US and Japan, as well as a slow-trend growth in gross domestic product (GDP), or economic output, in other high-income countries, "could trigger sudden adverse shocks".

In effect, the current problems that the world economy faces are a reflection of the broader inability to contain the political power of finance. In the US, the dilemma resulted from an almost farcical and essentially political conflict about whether the formal debt ceiling on the US government debt can be raised. This limit on the debt ceiling is itself the result of a rather odd piece of legislation that was passed in 1939 and then in 1941 as The Public Debt Act, in which the US Treasury was allowed to issue debt to fund federal government operations, but only within a stated ceiling.

Since this ceiling was defined in monetary terms (rather than, for example, as a ratio of GDP), it constantly had to be increased over the past seventy years. Since the late 1970s, the US Congress has more or less automatically raised the ceiling when passing the budget. The most recent such increase was in February 2010, when the limit was raised to $\$ 14.3$ trillion. But this time around, the Republicans in Congress, pushed by Tea Party activists who wanted to reduce government costs, dug in their heels and demanded severe budget cuts on social security and similar spending.

They also refused to undo any of the massive tax cuts on the rich that were provided by the Bush administration, which could have operated to reduce the deficit. This intransigence and the inability therefore, of the two sides to come to an agreement, created an unprecedented situation, in which the US government faced the prospect of a default on some of its debt if the debt ceiling were not raised! Even if this game of brinkmanship had come to a satisfactory end for now, the underlying message is that one way or another the US government is going to be forced to cut down on its spending. With the evidence of the weakness of the economic recovery becoming ever more apparent 
in the low-job generation and high unemployment figures, this in turn means that the US economy will be looking towards external demand to enable its recovery. On the other side of the Atlantic Ocean, things are even worse.

A major financial crisis in Europe has been temporarily staved off by an emergency summit of Eurozone leaders, in which Germany and other creditor countries agreed to let the European Central Bank provide a new Euro 109 billion rescue deal for Greece that would allow for extending of the maturities of all government debts due to be repaid before 2020 .

Most significantly, the banks have been forced to take some haircut in the form of a 20 per cent write down of the value of their outstanding debts. This is a step in the right direction, especially as the bond market contagion had already hit not just Portugal and Ireland once again, but also touched on the far bigger economies of Italy and Spain, creating fears of an unresolvable meltdown. But it is being argued that this is still too little, too late.

As a fund manager has noted, "This programme is less sticking plaster and more of a proper bandage, but that still doesn't deal with the underlying issues." The debt write-off is relatively small and officially "voluntary", covering about 80 per cent of Greece's creditors - but it is estimated that around three times that amount will eventually have to be written off if the Greek economy is to achieve a viable public debt to GDP ratio. But in any case, this bailout is being provided with the most stringent conditions requiring further fiscal austerity, which are bound to adverser after growth prospects in Greece.

So all the deficit countries in the Eurozone are being forced to engage in deep and wide ranging cuts that will reduce economic activity even as other European economies like the UK and surplus countries like Germany also announce measures to cut public spending!

Even recent empirical research from the IMF has found that fiscal consolidation has contractionary effects on domestic demand and therefore on GDP. One per cent of GDP cut in the fiscal deficit was found to typically reduce GDP by about 0.5 per cent within two years and raised the unemployment rate by about 0.3 percentage points. The general presumption is that external markets will provide the dynamism required to generate growth in these economies. But 
obviously, all countries or regions of the world cannot rely on net exports to make their own economies grow, especially if they are intent on suppressing domestic wages and demand to make their own economy more "competitive". Even China, currently seen as the economic powerhouse of the world, has seen some decline in demand growth in the past two quarters, and in any case its economy is simply not large enough to balance the impact of compression in the US and Europe. So where is demand for stable global economic expansion to come from?

Table 1

GDP Growth Estimates \& Projections by the IMF

\begin{tabular}{lcccc}
\hline & 2008 & 2009 & 2010 & 2011 \\
\hline World Output & 2.8 & -0.6 & 4.8 & 4.2 \\
Developed Countries & 0.2 & -3.2 & 2.7 & 2.2 \\
Developing Countries & 6.0 & 2.5 & 7.1 & 6.4 \\
\hline
\end{tabular}

Source. IMF world economic outlook, October 2010.

Table 2

World Bank Global Economic Prospects, June 2010

\begin{tabular}{lcccc}
\hline & 2008 & 2009 & 2010 & 2011 \\
\hline World Output & 1.7 & -2.1 & 3.3 & 3.3 \\
Developed Countries & 0.4 & -3.3 & 2.3 & 2.4 \\
Developing Countries & 5.7 & 1.7 & 6.2 & 6.0 \\
\hline
\end{tabular}

Note. Figures for 2008 and 2009 are estimates, while that for 2010 and 2011 are forecasts.

\section{The Financial Babbles}

The bulk of wealth under capitalism is held not directly in the form of physical assets, but indirectly in the form of claims over physical assets, i.e. in the form of money and financial assets; and these indirect claims too have multiple "layers", i.e. a wealth-holder holds a claim on a claim on a claim on a claim over a physical asset, like a factory or a building. All these claims have values in terms of "money". The values of these claims, vis-a-vis the world of commodities, which is ultimately what matters, may change, either because their 
values vis-a-vis money change, with the value of money itself vis$a$-vis commodities remaining unchanged, which is what happens through "bubbles" and their collapse; or they may change because the value of money itself changes vis-a-vis the world of commodities. Since "bubbles" (and their collapse) typically affect particular types of claims, which is why we talk, say, of the "dotcom" bubble or the "housing bubble". It is the latter kind of collapse, namely in the value of money vis-à-vis commodities, which affects the commodity value of all claims, that is far more serious for the capitalist system. How such collapses are prevented, i.e. how is the value of money vis-a-vis commodities maintained?

It is a mistake to think that within any country, the value of money vis-à-vis commodities is maintained through government diktat, i.e. that intrinsically almost worthless bits of paper which carry value vis$\grave{a}$-vis commodities because they have the imprimatur of government prescription (including the fact that the government collects taxes in these bits of paper).

To see this we just have to visualise a situation of hyper-inflation which entails a collapse in the commodity value of money. In such a situation, no government diktat will make people hold money or money-denominated (financial) assets. There must therefore, be something else that prevents such situations from arising, and that must be intrinsic to the functioning of the system itself. That something consists of the fact that money wages are typically kept fixed in any period, and made to change only slowly, if at all, over time. The value of money within any economy is in reality maintained by this fact, namely that the value of one crucial commodity, viz, labour power, is fixed in terms of it.

How did the credit crunch at the end of 2007 become a full financial meltdown by the middle of 2008, and finally turn into a global recession?

HSBC reveals huge losses at its US mortgage arm Household Finance due to subprime losses, in one of the first signs that the US housing market is turning sour, and that it could have a knock-on effect on the global financial sector. Global economic growth started to decelerate on a broad front in mid-2011 and is estimated to have averaged 2.8 per cent over the last year. This economic slowdown is expected to continue into 2012 and 2013. The United Nations baseline forecast for the growth of world gross product (WGP) is 2.6 per cent for 2012 and 3.2 per cent for 2013, which is below the pre-crisis pace of global growth. ${ }^{9}$ 
IJMS 20 (1), 109-163 (2013)

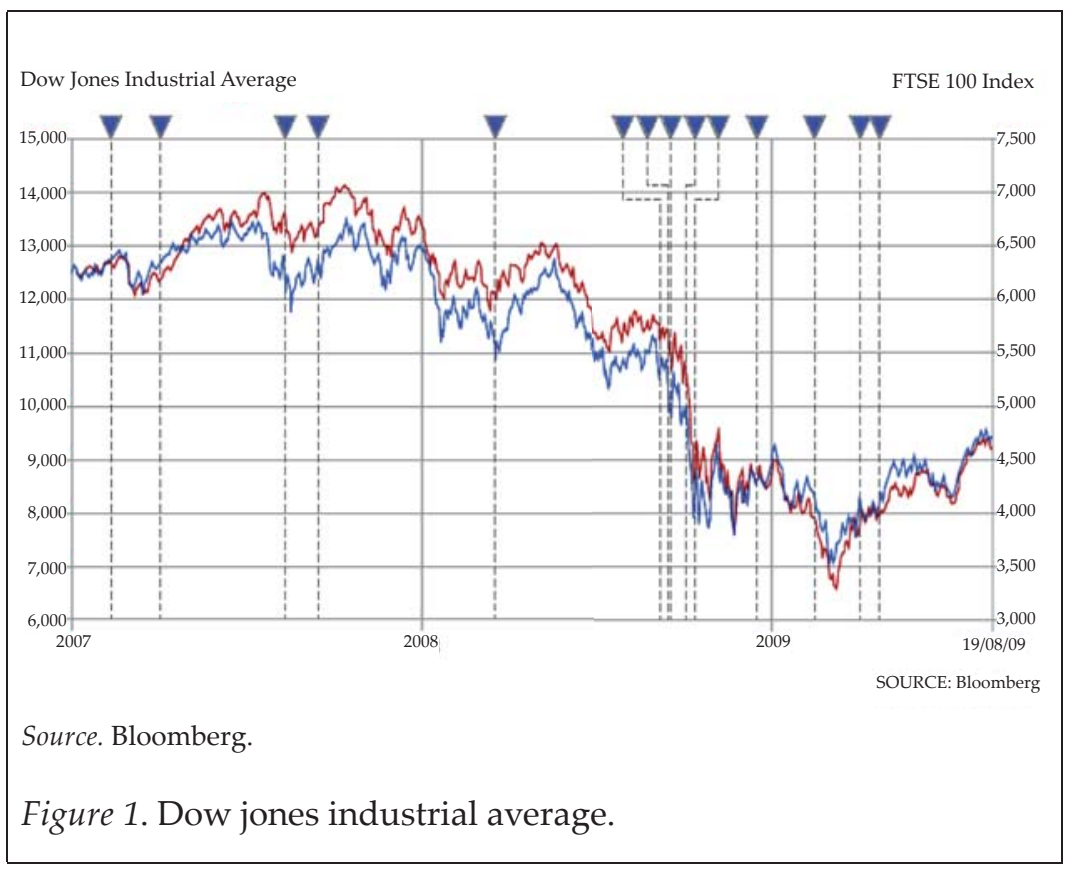

Persistent high unemployment in the United States and low wage growth are holding back aggregate demand and, together with the prospect of prolonged depressed housing prices, have heightened risks of a new wave of home foreclosures. Growth in the euro zone has slowed considerably since the beginning of 2011 and the eversimmering sovereign debt crisis heavily weighs on consumer and business confidence across Europe. The failure of policymakers in developed countries to address unemployment and prevent sovereign debt distress and financial sector fragility from escalating has posed the most acute risk for the global economy in the outlook for 20122013, with renewed global recession being a distinct possibility.

Meanwhile, developing countries and economies in transition are expected to continue to stoke the engine of the world economy, growing on average by 5.4 per cent in 2012 and 5.8 per cent in 2013 in the baseline outlook. Among the major developing countries, growth in China and India is expected to remain robust. GDP growth in China slowed from 10.3 per cent in 2010 to 9.3 per cent in 2011 and is projected to slow further to below 9 per cent in 2012-2013. India's economy is expected to expand by between 7.7 and 7.9 per cent in 2012 $\neg 2013$, down from 8.5 per cent in 2010. 
Low-income countries have experienced only a mild slowdown. In per capita terms, income growth slowed from 3.8 per cent in 2010 to 3.5 per cent in 2011 and, despite the global downturn; the poorer countries may see average income growth at or slightly above this rate in 2012 and 2013. The same holds for average growth among the United Nations category of least developed countries (LDCs).

Against this background, the report discusses several policy directions which could avoid a double-dip recession, including: optimal design of fiscal policies to stimulate more direct job creation and investment in infrastructure, energy efficiency and sustainable energy supply, food security stronger financial safety nets better coordination between fiscal and monetary policies and the provision of sufficient support to developing countries in addressing the fallout from the crisis and the coordination of policy measures at the international level.

\section{Global Economic Outlook 2012}

Until at least the middle of the next decade, global growth is likely to slow to approximately 3 per cent per year on average-a rate somewhat below the average of the last two decades. A recovery in advanced economies will be more than offset by a gradual slowdown in emerging ones as they mature, with the net result that global growth will be slow. But the biggest risk ahead for the global economy is not this slower overall growth in output but a slowdown in average output per capita, which will determine how fast living standards can be supported and raised.

\section{Main results}

- Global growth is projected to grow at 3.5 per cent in 2012, then accelerate somewhat to 3.6 per cent from 2013-2016, and then show a further slowdown to 2.7 per cent from 2017-2025. At 3 per cent, on average, global growth will still be somewhat higher than the period 1980-1995 but between half and a full percentage point below the growth rate from 1995-2008.

- Advanced economy growth is expected to slow down from an already meager 1.6 per cent in 2011 to 1.3 per cent in 2012. For 2013-2016, the outlook suggests some recovery in advanced economies, bringing these countries back to the pre-recession growth trend of a little more than 2 per cent.

- In 2012 emerging economies will be slow in growth by 0.7 percentage points on average, going from 6.3 percent growth 
in 2011 to 5.6 per cent in 2012, partly as a result of slower export growth and partly because several of them have been growing above trend. From 2017-2025 emerging and developing countries are projected to grow at 3.3 per cent. Many economies will begin to show signs of maturing, at which point the rapid catch-up growth abates.

- The greatest challenge for the global economy in this slow growth environment is to raise productivity without losing job opportunities for the millions who are looking for reasonably paid jobs to support their living standards. The growth rate of per capita income globally has been around 2.5 per cent since the beginning of the century but sometime between 2017 and 2025 this rate will fall below 2 per cent. In contrast to the past half century, that slowdown will also be accompanied by a slower growth in population.

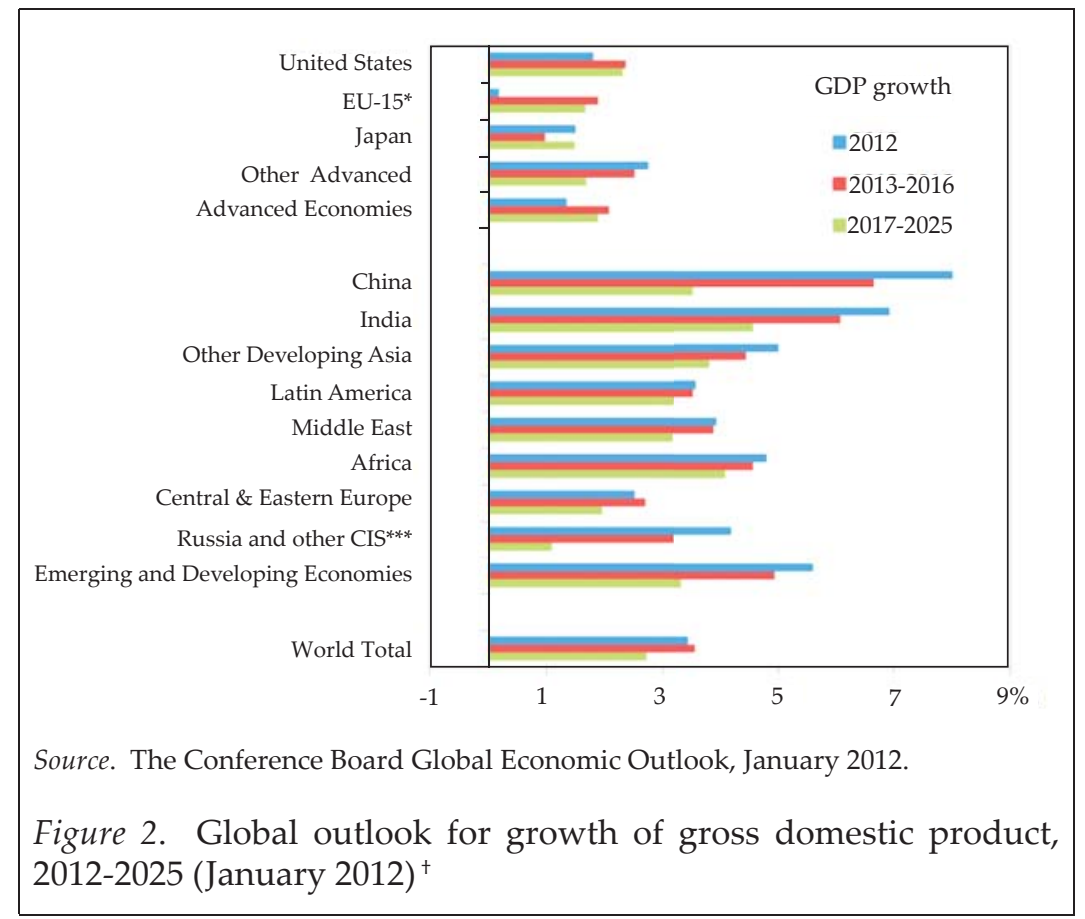

* EU-15 refers to states that joined the European Union before 2004.

** Other advanced economies include Canada, Switzerland, Norway, Israel, Iceland, Cyprus, Korea, Australia, Taiwan Province of China, Hong Kong, Singapore, New Zealand and Malta.

*** CIS is Commonwealth of Independent States which includes all former republics of the Soviet Union, excluding the Baltic States. 
IJMS 20 (1), 109-163 (2013)

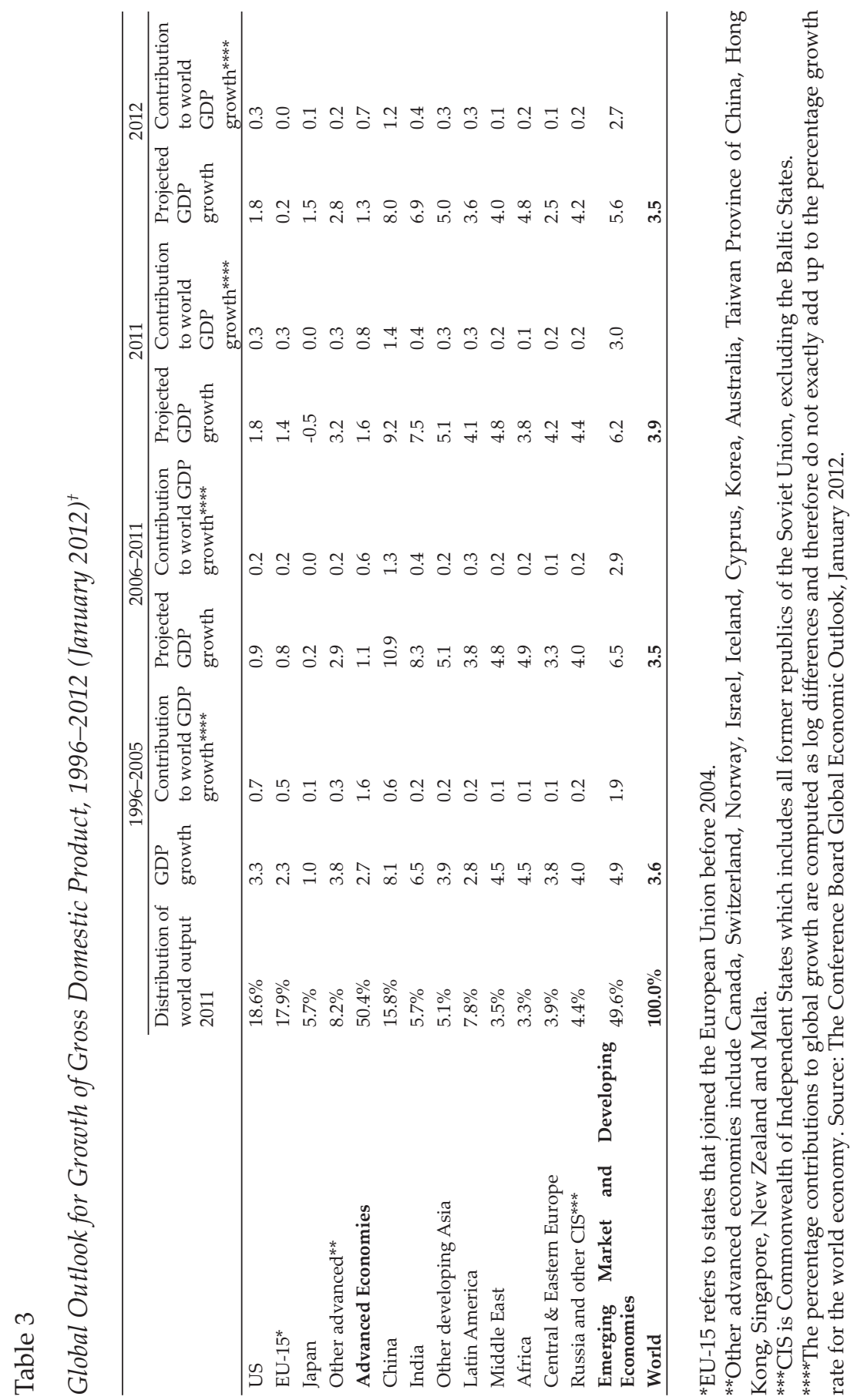


IJMS 20 (1), 109-163 (2013)

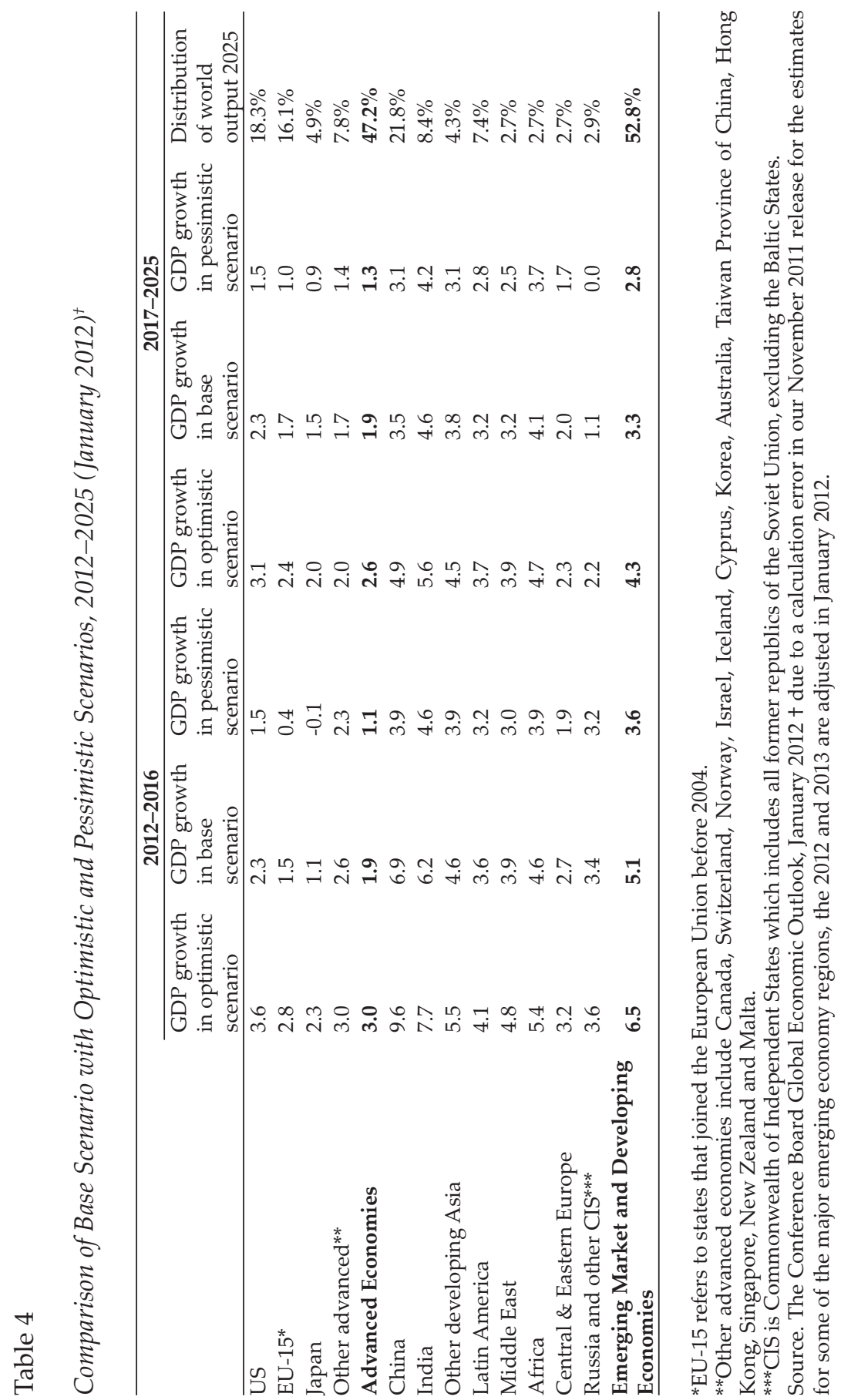




\section{Volatile Period for Global Markets}

It has been a volatile period for global markets, driven by almost unprecedented uncertainty amongst investors about the global economy and fears that politicians may be unable to fix economic problems. Recent economic data has suggested that the recovery in the West may be petering out, feeding renewed worries about the euro zone debt crisis. This, it is feared, could in turn cause a second banking crisis if governments are unable to pay back their debts. And in the face of these twin concerns some investors say policymakers have not done enough to provide certainty about how the crisis will be tackled.

The key factor worrying investors is slow growth in the US and Europe. The best credit rating that can be given to a borrower's debts, indicating that the risk of borrowing defaulting, is minuscule.

The International Monetary Fund has warned that the global economy has entered what it calls a "dangerous new phase" of low growth and high public debt. It significantly reduced its growth forecast for the world's advanced economies, predicting GDP growth of just 1.5 per cent this year.

$\%$ Change from proceeding period in GDP

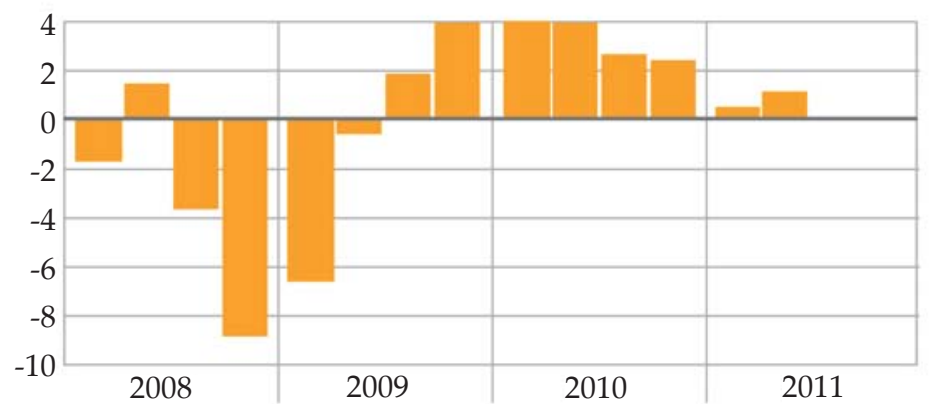

Source. Bureau of Economic Analysis.

Figure 3. Revised US GDP shows slow growth.

The US Federal Reserve has also painted a pessimistic picture of the economic outlook. "There are significant downside risks to the economic outlook, including strains in global financial markets," said 
the US central bank in a statement. The US economy created 103,000 new jobs in September, ahead of many economists' expectations. But the jobless rate was stuck at 9.1 per cent, according to the latest data from the Department of Labour. The US Commerce Department said that the world's largest economy grew at an annualized rate of 1.3 per cent between April and June.

The euro zone's manufacturing sector is still in the doldrums, with output in September falling at its fastest pace in two years, according to Market's Euro zone Manufacturing Purchasing Managers Index. Growth in the German economy also slowed sharply between April and June, growing by just 0.1 per cent in the quarter. The French economy was flat during the same period. The concerns about growth have also fuelled worries about the indebtedness of the euro zone states. If economies are not growing, tax receipts fall, making it harder for governments to pay off their debts.

So far Greece, Portugal and the Irish Republic have received international help to deal with their crippling debt problems.

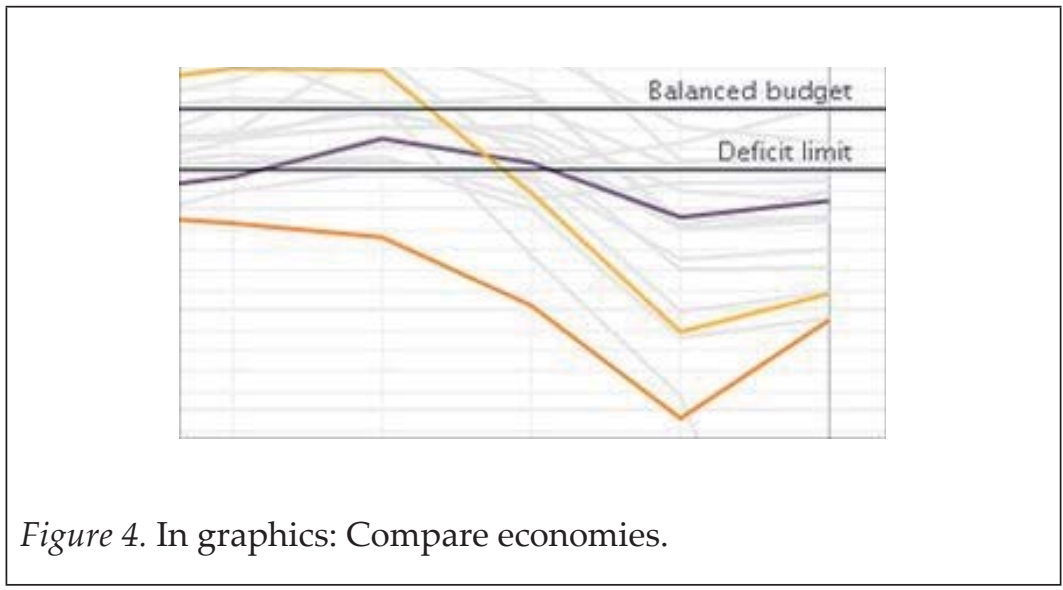

In early October, Italy's credit rating was slashed by Moody's from Aa2 to A2, with the ratings agency blaming a "material increase in the long-term funding risks for the euro area" due to lost confidence in the euro zone governments' debts. Italy follows fellow euro zone countries Spain, the Republic of Ireland, Greece, Portugal and Cyprus in having its credit rating downgraded this year. In July, 2011, euro zone leaders agreed to a second bailout deal for Greece, and also agreed to more powers for the European Financial Stability Fund to 
help countries struggling with indebtedness. This allowed the fund to buy government debts (bonds), offer credit to nations in difficulty and create a special facility for recapitalizing banks.

It included an agreement by private banks to swap existing Greek debt with longer-term debt paying lower interest. The enlarged euro zone rescue fund was ratified in most of the 17 nations that use the single currency, including Germany. But Italy's problems, in particular, meant the July deal was soon seen as insufficient. Following its role in the Greek bailout, the EFSF was estimated to have just 250bn Euros (\$350bn, £219bn) left, which was not enough to guarantee a loan to a large economy like Italy for more than a year. In October, the 2011 European leaders agreed to a series of new measures to try to prevent the debt crisis from spreading.

The EFSF will be boosted to ensure it can insure loans made to governments such as Italy up to a value of $1 \mathrm{tn}$ Euros. In addition; banks will have to write off a larger portion of the Greek debt. To prepare them for this and any future losses they will have to increase the capital they hold by more than 100bn Euros between them, if necessary with intervention from national governments.

There are, of course, two other alternatives available to Greece in this example: one is a deflation in money wages within Greece without a change in the exchange rate, which would lower Greek prices, compared to those of other countries and may improve the Greek balance of payments. But since the price fall within Greece would in such a case be less than the fall in money wages, the effect in terms of immiserising the working population would be much the same as discussed earlier.

The other alternative is to carry out an exchange rate depreciation (which, of course, in the concrete case of Greece is not possible since Greece is part of the Eurozone without any currency of its own). Any exchange rate depreciation, however, to be effective, must entail a reduction in wage share (since there are always some imported inputs whose domestic currency costs go up with the rise in foreign exchange price, and with capitalists enforcing fixed profit margins, net exports can improve only if wages do not increase at the same rate as the price of foreign exchange). In addition, in the context of any significant decline in the world aggregate demand, it is not one but many countries that would be in a plight similar to Greece. Exchange rate depreciation therefore, will necessarily invite retaliation from 
other similarly-placed countries; and what is more, even countries that have balance of payments surpluses despite the decline in world demand would still be facing some unemployment and recession, and they too would join in the game of retaliation rather than lose their markets. In short, an exchange rate depreciation which amounts to a "beggar-my-neighbour" policy will invariably invite significant retaliation if undertaken in the midst of a world recession.

It follows therefore that in a world where capital, especially finance, is free to move around globally, any initial decline in world demand gets magnified through the imposition of what are called "austerity" measures, i.e. measures to cut back domestic absorption. This is what we are actually seeing in the context of Greece where severe austerity measures are being imposed. There are, however, two points about this imposition of austerity that need to be noted. First, it is often thought to be merely a "stupid" policy which is imposed only because of "bad economics". But that is not the case: it is dictated as we have seen, by the interests of finance capital. To be sure, any "austerity" and worsening of the condition of the working population jeopardises the viability of the system and hence cannot be in the "long-term interests" of any capital, but since capitalism is not a planned but a spontaneous system such "long-term interests" do not usually figure in the calculations of capital (otherwise there would never have been world wars).

The second point is a technical one. It is often argued that if Greece had a central bank of its own from which its government could borrow (by printing money), then the whole problem of its government getting indebted to foreign banks and having to impose "austerity" would not have arisen. But this too is not true. The problem of that country's debt (and of many other countries) arises because of a balance of payments problem caused by the world recession. Even if the government borrowed from the central bank and not from foreign banks, the country would have had to borrow from abroad to meet its balance of payments deficit, caused by the fact that its level of domestic activity was held up inter alia by government expenditure not being slashed even in the face of declining exports. Exactly the same problem of debt therefore would have faced the country, even if the government financed its deficit by printing money.

To see this clearly, let us assume for simplicity that the private (including the household) sector's budget is always balanced. Then the fiscal deficit is always equal to the current account deficit on the 
balance of payments. Let the fiscal deficit be 100 and let it be financed by the central bank printing money which it hands over to the government against government bonds. To meet the current account deficit, however, the central bank has to borrow 100 from abroad, i.e. it has to obtain 100 in foreign exchange against 100 of its own IOUs. The 100 of newly-printed money given to the government must come back to the central bank to be exchanged against 100 of foreign exchange, which means that the government, though apparently borrowing from the central bank, is indirectly borrowing from abroad, mediated through the central bank.

The changes are partly designed to tackle fears that worries over sovereign debt could spill over to the banking sector. When shares have fallen they have often been led by bank shares as investors worry about what level of euro zone government debt they are holding, and whether this will be repaid.

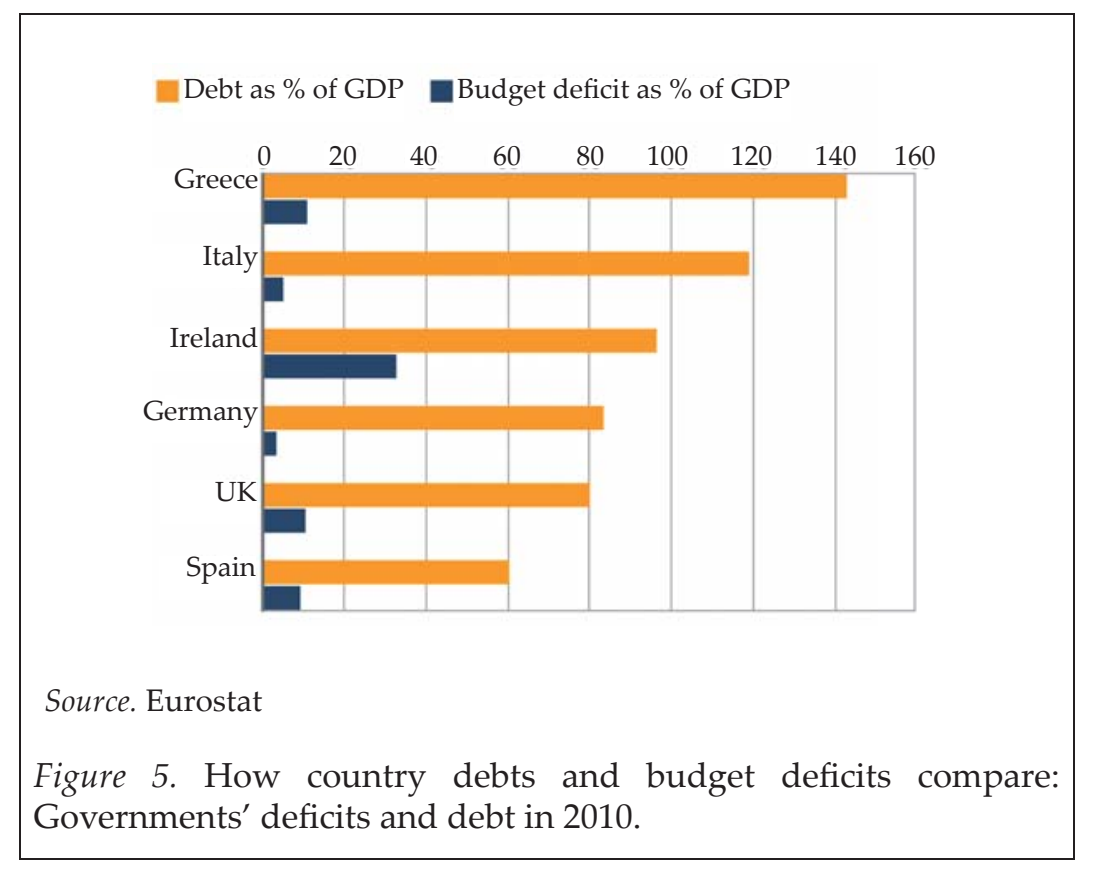

French banks have come under particular pressure as they hold more than 40bn Euros (£35bn) of the Greek debt, for example, almost four times more than any other country. The Institute of International Finance, a global trade body representing big banks and their major lenders, has said the Greek debt swap deal implies a loss for Greek 
lenders equivalent to 21 per cent of the market value of their debts. This will now increase to 50 per cent. If banks were forced to accept similar or greater losses on the debts of other countries it could trigger a new banking crisis, further destabilizing the global economy.

Meanwhile, there has also been concern about the US's ability to repay its debts, with Congress agreeing on a deficit reduction plan only at the 11th hour. This delayed deal also led to the credit-rating agency Standard \& Poor's cutting the long-term US rating by one notch from $\mathrm{AAA}$ to $\mathrm{AA}+$ for the first time.

The G20 group of leading economies has said it is ready to "take action" to stabilize global markets but there is disagreement as to what form that action would take. A statement is expected during its next meeting at the start of November. Any global action will be based on the steps taken at the regional and national level. With deficits already at record highs, governments have very limited room to manoeuvre.

US President, Barack Obama, has unveiled a \$450bn ( $£ 282 \mathrm{bn}$ ) package of tax cuts and spending plans aimed at creating jobs and bolstering the economy. But the plans have run into trouble in Congress. European leaders are under particular pressure to provide longterm stability for the single currency. October 2011's expansion of the EFSF, recapitalization of the banks and further write-off of private sector Greek debt are designed to provide that sort of reassurance. EU leaders also agreed to a further 130bn Euros bailout for Greece, some of which will be used to assist the further write-off of the Greek government debt. However, announcing the latest deal, European Commission President, Jose Manuel Barroso, admitted that this was unlikely to be the last package they provided. "I've said it before and I'll say it again, this is a marathon not a sprint."

While the package may reassure investors, questions remain about how it will be funded. It is not yet clear who will fund the expansion of the EFSF if the loans it insures are not paid back. The recapitalization of the banks and the write-off of Greek debt have not yet been explained in detail. World stock markets have rounded off a wild and difficult year. The UK FTSE 100 fell 5.6 per cent in 2011, while the French and German markets saw falls of 17 per cent and 15 per cent respectively as growing fears for the survival of the euro took their toll. But the US stocks ended the year up. 
Meanwhile, the euro ended 2011 close to a 15-month low against the dollar. The euro zone crisis has had a massive impact on global markets, as investors nervously awaited a plan to ensure Italy's government could continue to support its enormous debts. The US and Europe, including the UK, have also come to accept that it may be many years before their heavily-indebted economies regain their former dynamism.

\section{Financial Markets Crashed after Crashed: Capitalism Failed}

Foreign investors do not like to invest in the real (physical) economic sectors, as they always prefer sharing in the share markets. They are committed to make huge profits for short-term goals only. Any decline in aggregate world demand brings enormous hardships to the working population, not just because of its direct effects but, additionally because of its "multiplier effects" via "austerity".

The question that naturally arises is: how has capitalism managed to avoid such a denouement throughout its history, except to an extent during the Great Depression of the 1930s. The simple answer to that is: through its colonial empire. The colonies of possession, like India, (and semi-colonies like China), directly absorbed the goods, notably textiles, of the leading capitalist power of the time, Britain, which were unsalable elsewhere. In return they gave a larger amount of their own goods, not just of an equivalent value, gratis to the leading capitalist power(s) for investment in the "new world" to which an enormous wave of migration was taking place that expropriated land from the local inhabitants there, and reduced domestic unemployment in the metropolis.

\section{Colonial Legacy}

The colonial system, taking both colonies of possession and colonies of settlement, ensured two things, both crucial for financial stability of the capitalist world in a regime of free financial flows, as was the case under the Gold Standard. The first was the absence of any serious deficiency of aggregate demand for metropolitan goods. (The price-fall that occurred in the late nineteenth century, to which the term "Great Depression" used to be, and still is often, attached, may be cited as a counterexample to this, but the price-fall was essentially in primary commodities and got passed on to manufactures. It actually raised 
the value of money and contributed to financial stability under capitalism rather than instability). The second contribution of the colonial system was that it simultaneously prevented any inflationary pressures. A high level of aggregate demand runs the risk of generating inflation, but the colonial taxation system which appropriated primary commodities gratis ensured that excess demand pressures in the metropolis were kept at bay. The colonial system therefore was admirably suited to ensure the financial stability of a capitalist world open to free capital flows.

The exhaustion of the scope for the colonial system to play this role (rather than the fact of political decolonisation per se in a juridical sense), which is a result both of the fact that the third world markets now are too small relative to first world capacities and needs, and also of the fact that the share of the third world primary commodities, with the exception of oil, in the gross value of metropolitan output has shrunk to remarkably low levels (thanks inter alia to a long history of adverse terms of trade movements against such commodities), entails an end of this phase. This source of financial stability can no longer be relied upon.

\section{An Era of Keynesianism}

Keynesianism, of course, opened up another possibility, namely State intervention in economies across which capital movement was controlled, for stabilising the system. World aggregate demand was kept up, because, whether through military Keynsianism (as in pre-war Japan and Germany or post-war US), or through welfare Keynesianism (such as what European social democracy effected), the State intervened in every metropolitan economy to keep up the level of demand. True, the system lacked any bulwark against inflation, a fact already anticipated by prescient radical Keynesian economists like Joan Robinson, but competition among themselves to the export of primary commodities by newly-industrialising third world countries, each trying to earn as much foreign exchange as possible for importing machinery and "maintenance imports", kept inflation at bay for a long time in the post-war period. It did finally emerge in the late sixties and early seventies, but meanwhile gigantic accumulations of finance, owing inter alia to persistent US fiscal deficits that increased greatly during the Vietnam War, had pushed the world beyond the Bretton Woods system and into a regime once more of globalised finance. 
This regime of globalised finance today, however, does not have the prop of the colonial system, which is the root-cause of its travails. Because it is a regime of globalised finance, Keynesian demand management becomes difficult, not just for other nation-States that are constrained to follow "sound finance" to "retain the confidence" of internationally mobile finance capital, but even for the leading nation-State, the US, in whose case enlarging the fiscal deficit "leaks out" as larger current account deficit on the balance of payments and hence increases net indebtedness of the US, ironically for financing employment elsewhere. This, together with the fact that colonial markets are of little significance, means that the system has to rely on "bubbles" for its booms; the collapse of such "bubbles" brings recessions, which for reasons already discussed get magnified via what may be called the "austerity multiplier".

The proposition that the exhaustion of colonial (pre-capitalist) markets constitutes a sort of climacteric for capitalism was advanced by Rosa Luxemburg. She, of course, had visualised this "exhaustion" in terms of a complete assimilation of the pre-capitalist segment into the capitalist one, i.e. as a state of universal extension of the metropolis; and she had argued that such "exhaustion" would mean a "break-down" of the system where further accumulation became impossible. In both these respects she was wrong: the metropolis never gets universalised and the pre-capitalist economy never actually disappears, no matter how much it is squeezed; and systems do not just break down. But in postulating a climacteric for capitalism associated with the "exhaustion" of the scope for colonial and semi-colonial exploitation, she had shown great prescience.

The sense in which this "exhaustion" occurs has already been discussed above. The climacteric consists not in any "break-down" but in the fact that the system tends to turn with much greater savagery upon the working people within the metropolis itself (to which the diffusion of capitalism to erstwhile colonies and semicolonies further contributes). The social stability of capitalism gets greatly undermined, its presentation of itself as a humane system suffers a blow, as is happening in Greece today. True, a new "bubble" may arise that may temporarily refurbish its image, but its inevitable collapse will once again make it turn with enhanced viciousness upon its own working population, not just the working population of the "outlying regions" which has always been its target. 
If capitalism could create a "world state", in consonance with the globalisation of capital, where individual economies' having balance of payments surpluses or deficits did not matter because the "world state" would affect suitable transfers across them, then the particular problem highlighted here would disappear. The problem of inflation, arising from shortages of primary commodities like food and fuel would still remain, because the capitalist "world state" would continue to squeeze petty primary producers; but the "austerity multiplier" need not operate (which is exactly what those arguing that the EU should take over Greek debt are advocating at a "sub-global" level). Indeed Keynesian demand management by this "world state" would keep deficiency of world demand at bay but a system that oppresses petty producers both within and across nations, and sustains it through a whole ideology of racism and cultural superiority is intrinsically incapable of such internationalism. Internationalism in short cannot come piecemeal, through a "world state" that simultaneously oppresses petty producers, as capitalism spontaneously does: true internationalism is fundamentally incompatible with capitalism.

To say all this is not to suggest the imminence of an overthrow of the system, let alone a "beak down" which, of course, never occurs, since the class-preparedness for the former still remains a far cry. Besides, globalisation itself puts barriers against such class mobilisation through a process of "casualization", de-concentration, and fragmentation of workers (even as capital keeps getting concentrated in ever larger blocs), not to mention the hurdle imposed by the high rates of unemployment that weaken the striking power of the working class. But the irrationality and viciousness of the system is getting increasingly exposed and its legitimacy is getting undermined in the eyes of large masses of people (See Figure 5).

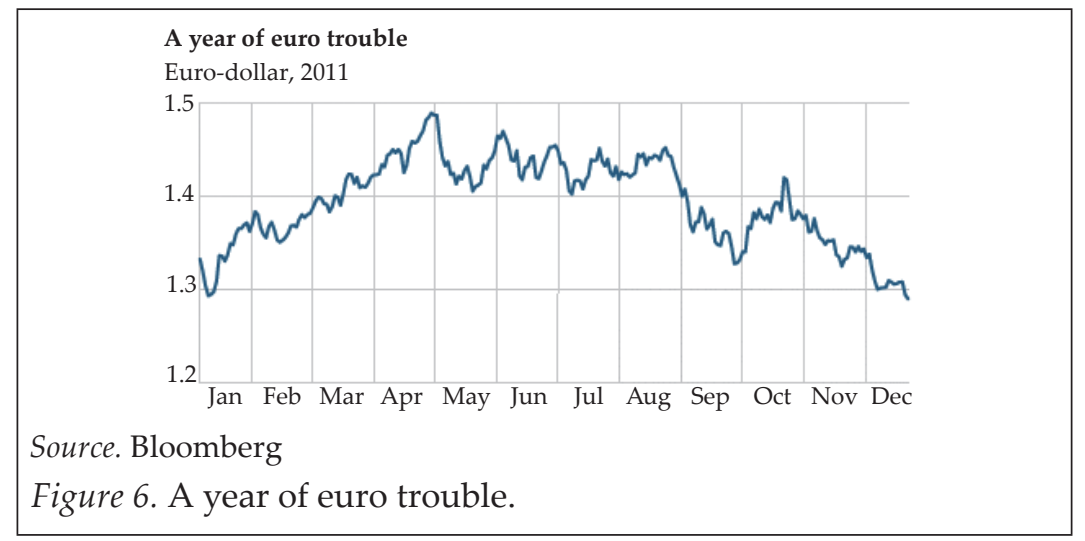




\section{US Troubles}

Financial markets started 2011 in an optimistic mood. But this was dramatically halted in the summer after the US lost its top AAA credit rating, following the political deadlock in Congress over raising the country's debt ceiling - the legal limit on the federal government's total borrowing. Much of the year has been dominated by the euro crisis, which came to the boil in August. The euro ended the year close to a 15-month low against the dollar after it shed more than $3 \%$ on 19th January 2012 (See Figure 6).

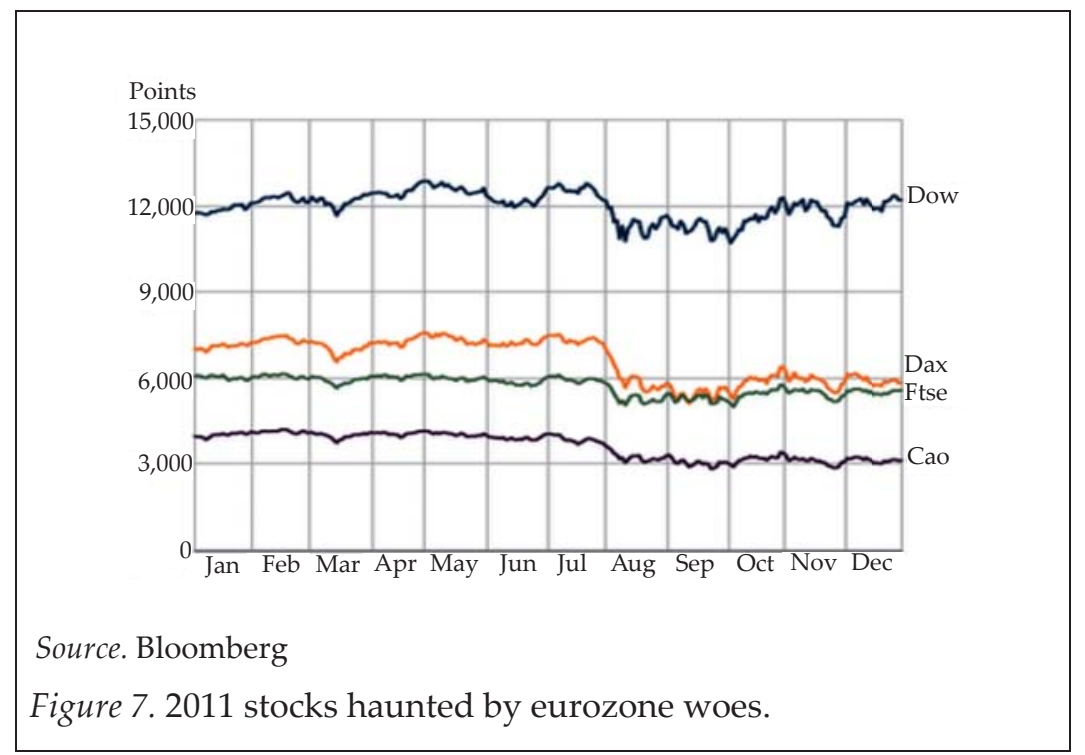

With fears over the future of the Eurozone, many analysts say it could drop even further in 2012. Of the heavily-indebted so-called PIIGS (Portugal, the Irish Republic, Italy, Greece and Spain) countries, Irish shares fared best. France and Germany look likely to bear the brunt of the bailout costs for the southern European states - and this was reflected in the performance of their equity markets.

In the first six months of 2011, US service imports were only 5 per cent higher than they were in the first six months of 2008, which implies a fall in real terms because of the depreciation of the US dollar in the intervening period. All this occurred while the stimulus packages still included some amount of fiscal expansion in the US. 
Unfortunately, the political charade around the debt ceiling that had just played out in Washington has almost completely ruled out the possibility of more government expenditure to combat the current fragility - instead, the current watchword is austerity and budget cuts. Quite apart from the implications for employment, welfare and inequality in the US, this is a further constraint on import expansion in the US economy. The growing resentment among the people in the US that is bound to be associated with these cuts will generate further protectionist pressures that will rebound on outsourcing and related tendencies. Since fiscal measures are being ruled out by politics, the only means left for the US to come out of this current stagnation is through monetary policy, though the effects of this are unlikely to be very positive. The real problem with the expansionary and low interest monetary policy being followed by the US Fed in the wake of the crisis has been that it has contained no measures to ensure that banks actually lend out in ways that improve economic activity, employment and the financial condition of the mass of consumers. But still no course correction is planned.

Instead, Ben Bernanke has just announced that interest rates will remain at their very low levels (close to zero) for the next two years at least. This may be fun for banks, but is not likely to stimulate domestic output in the US directly. But it will surely contribute to a weakening of the US dollar, which indeed may be part of the intention. The US Nasdaq and Dow Jones were rocked by the Americans' own financial woes in July, when the US rapidly approached its debt ceiling, risking default if agreement could not be reached by a polarized Congress to raise it. Despite ultimately raising the ceiling, rating agency Standard \& Poor's lowered the credit rating of the United States from AAA to $\mathrm{AA}+$, deciding that the budget plan that was passed did not go far enough to address the country's deficit - a move which wiped off 5.6 per cent of the Dow Jones Industrial Average in a single day.

On $20^{\text {th }}$ January, 2012, the Dow Jones industrial average closed down 69 points at 12,218, but remained higher than at the start of the year. Japan's stocks lost 17 per cent in 2011 in the wake of March's devastating tsunami, which saw 20,000 lives lost, and affected the production of some of the world's most vital component suppliers, not to mention severe damage to the country's energy sector, including a nuclear meltdown at the Fukushima Daiichi plant. Japan's Nikkei index closed at 8,429.45 on Friday - its lowest year-end close since 1982. 


\section{Germany Falls}

France's Cac 40 dropped 17 per cent and Germany's Dax fell 14.7 per cent over the year. By contrast, the German market was the best performer in Europe in 2010, so it marked a dramatic change in fortunes for the European 'powerhouse'. Overall, however, the UK FTSE 100 index was 5.6 per cent lower on the year, having fallen from $5,899.94$ to close at 5,572.28 over 12 months, with worries over the impact of the Eurozone crisis doing much of the damage.

This was in marked contrast to previous years-2010 saw a 9 per cent rise, while 2009 saw stocks rise in value by 22 per cent during the year. "As traders say goodbye and probably good riddance to 2011, a year that saw most of the European and Asian indices recording double-digit losses, traders may not be so welcoming 2012 either," said Jonathan Sudaria, a dealer at the brokerage, Capital Spreads. The one bright spark to 2011 has been the resilience of the US, given the weak global economic backdrop.

\section{Japan Posts First Annual Trade Deficit in 30 Years}

Japan has announced its first annual trade deficit in more than 30 years, a setback for a country known for its exports including cars and electronics. The deficit came in at 2.49 trillion yen $(\$ 32 \mathrm{bn}$; $£ 20 \mathrm{bn}$ ) for 2011. Japan's imports rose 12 per cent and its exports fell 2.7 per cent, compared to the previous year.

\section{Struggling Exporters}

The deficit underscored the pressure that Japanese exporters have come under since the disaster. Factories were damaged and supply chains disrupted for major exporters including Toyota Motor and Sony. Exporters' problems were exacerbated by further disruptions to production in some of their Thailand facilities due to flooding, as well by a rising yen, which made Japanese products more expensive overseas. Uncertainty surrounded Europe and the US caused global investors to turn to the yen, as a safer investment, causing it to appreciate. This meant that Japan's exporters faced losing their competitiveness even as rivals in South Korea and other Asian nations competed in markets which Japanese companies had previously dominated. 
However, given that Japan's major export markets, the US and Europe, were seen going into recession some analysts are forecasting that the trade deficit will continue. Takuji Okubo of Societe Generale in Tokyo said Japan would see a trade deficit till 2014 because of "the combination of a strong demand in Japan because of the earthquake and reconstruction demand, and a weak demand outside of Japan in Europe and the US".

\section{Crisis Impact on the Developing Nations: A Survey}

Developing country growth was revised down to 5.4 per cent from 6.2 per cent in the June 2011 projections. High-income countries were expected to grow a tepid 1.4 per cent this year, weighed down by a 0.3 per cent contraction in the 17-nation Eurozone. The World Bank projected that the United States, the world's largest economy, would grow 2.2 per cent this year as it slowly recovers from the Great Recession. The 30 developing countries with financing needs that exceed 10 per cent of GDP should seek to refinance those needs "now," the Bank said. It also recommended prioritizing the social safety net and the infrastructure programmes that are key to longer-term growth. Noting that a recent decline in commodity prices had eased inflation in most developing countries, the bank said that nonetheless "food security for the poorest, including the Horn of Africa, remains a central concern."

Developing countries should prepare for further downside risks, as Euro Area debt problems and weakening growth in several big emerging economies are dimming global growth prospects, says the World Bank in the newly-released Global Economic Prospects (GEP) 2012. The Bank has lowered its growth forecast for 2012 to 5.4 percent for developing countries and 1.4 per cent for high-income countries $(-0.3$ per cent for the Euro Area), down from its June estimates of 6.2 and 2.7 per cent (1.8 per cent for the Euro Area), respectively. Global growth is now projected at 2.5 and 3.1 per cent for 2012 and 2013, respectively. Slower growth is already visible in weakening global trade and commodity prices. Global exports of goods and services expanded an estimated 6.6 per cent in 2011 (down from 12.4 per cent in 2010), and are projected to rise by only 4.7 per cent in 2012. Meanwhile, global prices of energy, metals and minerals, and agricultural products are down 10, 25 and 19 per cent respectively since peaks in early 2011. Declining commodity prices have contributed to an easing of headline 
inflation in most developing countries. Although international food prices eased in recent months, down 14 per cent from their peak in February 2011, food security for the poorest, including in the Horn of Africa, remains a central concern.

Developing countries need to evaluate their vulnerabilities and prepare for further shocks, while there is still time, said Justin Yifu Lin, the World Bank's Chief Economist and Senior Vice President for Development Economics. Developing countries have less fiscal and monetary space for remedial measures than they did in 2008/09. As a result, their ability to respond may be constrained if international finance dries up and global conditions deteriorate sharply. To prepare for that possibility, Hans Timmer, Director of Development Prospects at the World Bank, said "Developing countries should prefinance budget deficits, prioritize spending on social safety nets and infrastructure, and stress-test domestic banks."

While prospects in most low-and middle-income countries remain favourable, the ripple effects of the crisis in high-income countries are being felt worldwide. Already, developing country sovereign spreads have increased 45 basis points on average and gross capital flows to developing countries plunged to $\$ 170$ billion in the second half of 2011 , compared with $\$ 309$ billion received during the same period in 2010. An escalation of the crisis would spare no one. "Developed-and developing-country growth rates could fall by as much or more than in 2008/09," said Andrew Burns, Manager of Global Macroeconomics and lead author of the report. The importance of contingency planning cannot be stressed enough.

The economic crisis affected developing countries through declining private financial flows, trade and remittances. IMF expects ASEAN economies, including Malaysia, to slow because of the external headwinds and weakening internal demand. The updated World Economic Outlook of Washington on 24 ${ }^{\text {th }}$ January, 2012, has revised downwards its growth forecast for ASEAN-5, which also includes Indonesia, the Philippines, Thailand and Vietnam, to 5.2 per cent for 2012.

Compared to its outlook four months ago, it now expects these economies to grow by 5.6 per cent in 2013. During 2012 to 2013, growth in emerging and developing economies is expected at an average 5.75 per cent, a significant slowdown from the 6.75 per cent growth registered during 2010-2011 and about 0.5 percentage point 
lower than that projected in the September 2011 WEO. "This reflects the deterioration in the external environment, as well as the slowdown in domestic demand in key emerging economies," the IMF said.

\section{Table 5}

\section{Overview of the World Economic Outlook Projections}

[Percent change unless noted otherwise]

\begin{tabular}{lrcccccc}
\hline Year over year & \multicolumn{5}{c}{ Projections } & \multicolumn{3}{c}{ Q4 over Q4 } \\
& \multicolumn{3}{c}{ Estimates } & Projections \\
\hline Developing Asia & 2010 & 2011 & 2012 & 2013 & 2011 & 2012 & 2013 \\
China & 9.5 & 7.9 & 7.3 & 7.8 & 7.4 & 7.9 & 7.6 \\
India & 10.4 & 9.2 & 8.2 & 8.8 & 8.7 & 8.5 & 8.4 \\
ASEAN-5 & 9.9 & 7.4 & 7.0 & 7.3 & 6.7 & 6.9 & 7.2 \\
\hline
\end{tabular}

${ }^{*}$ Note. Real effective exchange rates are assumed to remain constant at the levels prevailing during November 14-December 12, 2011.

*ASEAN -5: Indonesia, Malaysia, Philippines, Thailand and Vietnam.

Despite a substantial downward revision of 0.75 percentage point, developing Asia, which includes China and India (and ASEAN-5), was still projected to grow most rapidly at 7.5 per cent on average in 2012-2013. It was said the recovery of the supply chain disruptions caused by the March 2011 Japanese earthquake was also stronger, while stabilizing oil prices helped support consumption. But these developments, it added, are not expected to sustain significant momentum.

By contrast, growth in the emerging and developing economies slowed more than the forecast, possibly due to a greater than expected effect of macroeconomic policy tightening or weaker underlying growth. The IMF said that emerging and developing economies' near-term policy should focus on responding to moderating domestic growth and to slowing external demand from advanced economies. Some emerging economies with low debts and deficits and declining inflationary pressures have room to make policy more supportive of economic activity. Emerging economies highly dependent on commodity revenues and external capital inflows also need to consider the risk of a large and protracted decline in these flows. In September last year the IMF revised down its growth projections for the Malaysian economy from 5.5 per cent to 5.2 per cent for 2011, and 5.1 per cent for 2012. 
Supported by domestic demand, it expects Malaysia's growth to be led by robust investment to offset the slowdown in export momentum. The IMF warned that the risks to stability have increased, despite the various policy steps taken to contain the euro area debt crisis and banking problems. The US and other advanced economies will be impacted by spillovers from the euro area crisis. Developments in the euro area also threaten emerging Europe and may spill over to other emerging markets. Further policy actions are needed to restore market confidence.

\section{China Slowdown}

China's Shanghai Composite Index lost 22 per cent in 2011 as tighter government curbs on lending and investment cooled the country's rapid economic growth. The flood of state spending and bank lending after the 2008 crisis had fuelled a surge in house and stock prices. In 2010, Beijing responded by clamping down on credit and property speculators to cool inflation and soaring housing prices. Beijing is trying to ensure that economic growth remains at a more sustainable level after 2010's rate of 10.3 per cent. Growth eased to an annual rate of 9.1 per cent in the three months ending in September, down from 9.5 per cent on the previous quarter. Chinese Prime Minister recently announced in the Parliament, Chinese economic growth rate may fall in the current year 2012 at 7 per cent only".

\section{India Slowdown}

The Indian economy after a year of sluggish growth is now destined to bounce back. The World Bank has issued an ominous warning that the developing countries, India in particular, should be prepared for a crisis that will be on par or worse than the 2008-09 global economic meltdown. In India, that further financial liberalisation will attract an inflow of foreign funds providing an impetus for growth also appears remote with the World Bank warning that the rich countries had little monetary or fiscal ammunition available to stem any vicious circle of continuing recession.

Indian markets saw the second biggest fall in a decade this year. The Sensex, the Bombay Stock Exchange's benchmark equity index, ended trading at $15,543.93$ on $27^{\text {th }}$ January 2012, falling 24 per cent during the year. But foreign investors would have been doubly burnt, as India's 
rupee was one of the worst performing currencies this year, down $16 \%$ against the dollar. The increased tendencies for inflow of mobile capital, in the form of carry trade to take advantage of the interest rate differentials and because of perceptions of greater growth potential in these countries India. In the Indian case, the bursting of the bubble is likely to be even more painful, because even in the boom the growth process is simply not generating enough productive employment. So, a quick "recovery" from the current volatility need not be something to celebrate in India if it is because of renewed capital inflows, with their attendant unfortunate consequences.

The other potentially dangerous effect of the loose monetary policy, which has unleashed lots of cheap liquidity on global markets, has to do with primary commodity prices. At this moment, oil prices have fallen globally, but this may be just a temporary respite, and for other important commodities there is no clear decline. Gold prices are rising because of a flight to safety, but investing in other commodities may also keep increasing simply because investors do not know where else to go with their money, and because interest rates are so low that there is little to lose. This may well lead to further increases in global food prices, which will create havoc and threaten consumption across the developing world.

In India, in particular, the pressure on food prices is already so intense that we really cannot afford another trigger in the form of renewed global price increases. All in all, it seems that there are many potent sources of future instability that are implicit in the current global scenario. This does not mean, of course, that we should sit around wringing our hands with doomsday talk. But it certainly does mean that we - or rather, Indian policy makers - should be fully aware of these possibilities and develop strategies to cope with them.

\section{Three Major Features of Economic Policy in India}

Neo- liberal economic policies had three major features in the Indian context. The first was the withdrawal of support of the State from petty producers, leaving them to the mercy of the world capitalist market and to direct relationship with multinational giants engaged in agri-business on both the input and output side. This amounted to a going back on the promise of our anti-colonial struggle which had drawn the support of crisis-hit peasants in the 1930s by placing before them a picture of free India where the State would protect and 
promote their interests; but "neo-liberalism" had no qualms about reneging on it. The second was obtaining access for Indian goods and services, especially the latter, in advanced country markets, where the relatively lower Indian wages could give a boost to exports; and this is what underlay the growth in software and IT-related service exports. The third was creating an environment in the country that would draw global financial inflows and cause a domestic bubble; this was a major factor behind the high rates of GDP growth.

These three features together shaped our economic experience in the recent period. The growth in software and IT-related service exports created employment for the educated middle-class youth, contributed to the GDP growth story, and acquired prominence because of the expansion of cities like Bangalore. But the far more serious factor underlying the growth story was the inflow of finance. By preventing the exchange rate from appreciating, the Reserve Bank of India acquired huge foreign exchange reserves, which boosted the lending capacity of banks, even as the financial inflow was causing a stock market bubble. The result was burgeoning luxury consumption, not just by the very rich but also by an upper-middle class that was becoming affluent, and feeling even more so; and burgeoning investment for meeting this consumption demand. All this brought about high growth, and euphoric expectations about a "shining India".

The very fact of substantial foreign exchange reserves, which temporarily allayed fears of a rupee depreciation, and euphoric expectations about India being, alongside China, the new "happening place", kept bringing financial inflows to sustain the growth "bubble"; and whenever any dark clouds appeared on the horizon, the union government took measures to keep the euphoria going, for instance by virtually eliminating capital gains tax, and permitting capital inflows routed through tax havens like Mauritius.

The fact that this growth was accompanied by an increase in the magnitude of absolute poverty should cause no surprise. The agrarian crisis, acute penury of petty producers, the increasing impossibility of even simple reproduction on the part of large sections of peasants which has caused till now over two lakh peasant suicides, and distress migration from the countryside to the cities in search of non-existent jobs, which only swells the reserve army of labour, camouflaged as "informal sector employment", are all phenomena associated with growing absolute immiserisation. 
The most palpable manifestation of this growing absolute immiserisation is growing hunger. The proportions of population accessing less than 2200 calories per person per day in rural areas and 2100 calories per person per day in urban areas, which still constitute the official benchmarks for poverty, accepted even by the Planning Commission, were 69 per cent and 64.5 per cent respectively in 20045; in 2009-10, the latest year of large sample NSS, the figures have increased to 76 per cent and 73 per cent respectively. "Neo-liberal" policies, while causing high growth by attracting financial inflows to sustain a bubble, also caused increased absolute impoverishment, since the employment created by such growth was woefully inadequate to absorb the labour being released because of the crisis of petty production effected under the same policy regime.

The neo-liberal chickens however, are finally coming home to roost. The kind of growth India was experiencing was by its very nature fragile. The bubble that had developed could easily collapse and that would bring the growth story to an end; and any tendency for finance to flow out could cause such a collapse. This is exactly what is happening now. This may appear odd at first sight: do we not have enough foreign exchange reserves to weather any sudden outflows of finance? Do we not have a sound economy that would ultimately retain "investors' confidence"? To understand the fragility of our growth, two points need to be noted: first, any inflation in India, relative to other countries and in particular to the US whose currency is still considered "as good as gold", creates expectations of a depreciation of the rupee. If prices in India rise, say, by ten per cent, while they are constant elsewhere, then wealth-holders would generally expect a ten per cent nominal depreciation in the rupee, so that the "real effective exchange rate" remains unchanged, and with it the country's competitive position (otherwise the current account deficit would widen). But any expectation of depreciation in the nominal exchange rate is enough to make wealth-holders move from rupees to, say US dollars, causing an actual depreciation in the nominal exchange rate. When we recognize the additional fact that any nominal depreciation, by raising the prices of imported essentials like oil, generates under a neo-liberal dispensation where price-controls are eschewed, inflation in the domestic economy. We get a vicious circle: a chance depreciation in the nominal exchange rate generates inflation, which causes an expectation of a further depreciation in the exchange rate, which causes a further actual depreciation, leading to further inflation, further expectation of depreciation, further actual depreciation, and so on. 
In short, any slight shock can destabilize an economy that is open to financial flows and indeed thrives on such openness. Here we come to the second point: even if the government has plenty of foreign exchange reserves, using such reserves to stabilize the currency can have the opposite effect of making speculators move away from it. Any use of reserves is ipso facto a reduction in reserves, and with every such reduction speculators become more conscious that the government's ability to intervene in the foreign exchange market is declining, and hence become even keener to leave the currency. Since the magnitude of a sudden withdrawal of funds from a country can be enormous, even hundreds of billions of dollars overnight, the government finds itself in a bizarre situation; of sitting on top of a mountain of foreign exchange reserves and yet unable to do anything about a slide in the value of the rupee. This is exactly our current predicament.

The immediate trigger for the outflow of finance from India may have been provided by the Eurozone crisis, though of course, the rapid rate of inflation that the Indian economy has been experiencing for some time must be a major underlying contributory factor. Since the US dollar still remains "as good as gold" in the minds of wealth-holders, panic on their part in any part of the world, and hence a flight to dollar from any part of the world, triggers similar flight from other parts as well. There was, for instance, a brief period following the financial crisis in 2008 when there was an outflow of finance from India to the US, which should at first sight be surprising, since the US was where the crisis had broken out, but which was easily explicable by the fact that it was a panic flight to dollar. Hence the Eurozone crisis could well be a trigger. But even if the Eurozone crisis provided the trigger, both the context of inflation, and above all the basic fragility of the economy sitting atop a bubble and being dependent upon speculative financial inflows to keep it going, are the real causes of our present crisis.

It is a hallmark of the crisis, that every effort the government makes to end it, within a "neo-liberal" framework, will only succeed in worsening it. Since finance likes "austerity", there is a move on the part of the government, loudly supported by a chorus of financial columnists, to cut back government expenditure to rein in the fiscal deficit, in the belief that this would revive "investor confidence", i.e. entice finance back into the economy to keep the bubble going. But this will only succeed in accentuating the downturn in the economy, without reviving a collapsed bubble. Likewise, every effort on the 
part of the government to tighten the monetary policy in the belief that this would curb inflation and revive "investor confidence" will only end up compounding the economy's downturn.

The real remedy to the current economic malaise is to stimulate expenditure, especially government expenditure to offset sagging private expenditure. This, it would immediately be pointed out, would set off financial outflows, widen, other things being the same, the current account deficit, and accentuate inflation through imported-oil-cost-push. Yes, all these will happen if the government expands its expenditure within the neo-liberal policy framework. But if the government imposes a modicum of capital control, if it increases taxes on the rich and if it resorts to price control and public distribution of essential commodities, then it would be able to revive growth, and that too of a far more egalitarian kind, without having to kowtow to finance capital to sustain a bubble. It is within a neo-liberal framework that growth can occur only through bubbles; and such growth is necessarily poverty-enhancing. Outside such a framework, there is no reason why growth cannot occur that increases people's welfare, while controlling inflation and keeping the balance of payments on an even keel.

It requires, however, the removal of the hegemony of finance. All over the world, the consequences of the tyranny of finance are becoming clear by the day, and people are rising against this tyranny. Since the Manmohan Singh government, in thrall to finance, will continue to pursue neo-liberal policies to the detriment of the people, the time is fast approaching for such a popular upsurge in India too.

A mistaken impression may arise that since the high growth phase in India was accompanied by increasing absolute poverty, a reduction in growth, such as we are witnessing today, may actually mean a reduction in poverty. This however, is not true. The growth in poverty was because inter alia of the agrarian crisis, not only the crisis itself but also because it contributed to a swelling of the reserve army of labour which also kept down the real wages of the active army. The reduction in growth within the neo-liberal framework will not make the agrarian crisis, or the crisis of petty production in general, go away. State policy, within this framework, will continue to promote the interests of big corporates and finance capital, while sacrificing the interests of workers and petty producers. If anything, reduced growth will only further reduce whatever employment was being 
generated, which will have a further detrimental effect on poverty; and it will also affect unfavourably the middle class, consisting of the salariat, the white collar employees and professionals.

While East Asia and the Pacific region recovered quickly from the March 2011 Tohoku disaster in Japan, flooding in Thailand and the turmoil in Europe, have started to affect regional growth. After expanding by 9.7 per cent in 2010, regional GDP grew an estimated 8.2 per cent in 2011, but growth is projected to ease to 7.8 per cent for both 2012 and 2013. In China, which accounts for about 80 per cent of regional GDP, growth eased from 10.4 per cent in 2010 to an estimated 9.1 per cent in 2011 and is expected to dip to 8.4 per cent in 2012 as authorities continue to dampen "overly-fast" growth in particular segments of the economy.

GDP growth in Europe and Central Asia increased marginally from the 2010 outturns to 5.3 per cent in 2011, despite the global financial turmoil since August 2011 and weakening external demand, especially from the Euro Area. However, the expected slowdown in high-income Europe, still troublesome inflationary pressures in the region, and reduced capital flows due to the Euro Area crisis, may slow regional growth to 3.2 per cent in 2012, before firming to 4.0 per cent by 2013. Close trade and financial ties to high-income Europe will make regional outturns particularly sensitive to developments in the Euro Area.

Latin America and Caribbean grew by an estimated 4.2 per cent in 2011, but this is expected to ease to 3.6 per cent growth in 2012, before picking up to 4.2 per cent in 2013. Weaker global growth, uncertainty arising from the Euro Area debt crisis, slower growth in China, and a policy-induced deceleration in domestic demand are weighing on growth prospects. Brazil's economic growth came to a halt in the third quarter and growth is forecasted to be 3.4 per cent in 2012, up slightly on 2011 but well below the 2010 growth of 7.5 per cent. Several countries in the region could be hard hit, if international commodity prices were to weaken sharply. In Brazil, this is already seen as a major economic concern, as inflows of hot money push up the currency despite some attempts at capital controls. But policy makers in India are not necessarily as wise, and they may rather interpret the renewed inflows of footloose capital as a sign of the continued economic strength of India. That would be a mistake, because financial inflows in the current context will push up the exchange rate and further increase the trade deficit, which is already of significant proportions. It will further shift incentives in the economy away 
from tradable goods to non-tradable activities including real estate, construction, stock markets and debt-based personal consumption. These are classic signs of a bubble economy. As long as the bubble is in progress, it feels like a boom, but all bubbles do burst eventually.

Dramatic political changes in the Middle East and North Africa have disrupted economic activity substantially, but selectively, across the region, while a deteriorating external environment is beginning to amplify adverse effects on trade, commodity prices, tourism and other revenues. Developing oil exporters and the high-income GCC economies benefitted substantially from the rise in oil prices but they remained vulnerable to a sudden fall in these prices. GDP for the developing countries of the region grew by an estimated 1.7 per cent in 2011 and is expected to remain subdued in 2012 (2.3 per cent), rising to an expected 3.2 per cent gain by 2013 .

GDP in South Asia slowed to an estimated 6.6 per cent in calendar year 2011, from 9.1 per cent in 2010, reflecting a sharp slowdown in the second half of the year in India as well as external headwinds. Exports are negatively affected by weaker foreign demand and remittances have grown only modestly. Domestic demand is down sharply due to rising borrowing costs, high input prices, worries over the global slump, and delay in reforms. The region's GDP growth is projected to ease further to 5.8 per cent in 2012, before strengthening to 7.1 per cent in 2013. High inflation and fiscal deficits remain concerns going forward.

Growth in Sub-Saharan Africa remained robust in 2011 at 4.9 per cent. Excluding South Africa, which accounts for over a third of the region's GDP, growth in the rest of the region was even stronger at 5.9 per cent in 2011, making it one of the fastest growing developing regions. Increased investment flows, rising consumer spending, and the coming on stream of new mineral exports in a number of countries should accelerate Sub-Saharan Africa's growth to 5.3 per cent in 2012 and 5.6 per cent in 2013. Nonetheless, merchandise exports, tourism receipts, commodity prices, foreign direct investment and remittances are all susceptible to a Euro Area recession.

\section{Conclusion}

Imperialist driven (new-liberal) globalization's output can be seen. More than 50 million new people are being added to those below the poverty line and over 200 million are becoming unemployed in Europe 
and the USA. We have seen a powerful 'Occupy Wall Street' people's movement against poverty, inequality, unemployment and inflation not only in America, but also in the entire world-Canada, Europe, and Asia recently. The 'Occupy Wall Street' call is popular, and almost 186 countries (all over the world) have witnessed the same protest march. The American poor and the jobless working people gathered around 'Wall Street' and other 70 cities, and protested against big corporate sectors (as MNCs controlled more than two trillion dollars/USD 2, 00,000 crore).

Due to financial recession, the Bank of America announced 30000 jobs cut, and recently the American army announced a 212 per cent jobs cut. According to the latest population statistics of 2011 one American in six is poor. Almost 460 lakh people live below the poverty line in America. Global capitalism is not able to solve problems like poverty, inequality, malnutrition, unemployment, illiteracy, economic-socialcultural backwardness, and even the environment.

Table 6

Distribution of World GDP, 1989

\begin{tabular}{lc}
\hline Quintile of population & Income \\
\hline Richest 20\% & $82.7 \%$ \\
Second 20\% & $11.7 \%$ \\
Third 20\% & $2.3 \%$ \\
Fourth 20\% & $2.4 \%$ \\
Poorest 20\% & $0.2 \%$ \\
\hline
\end{tabular}

Source. United Nations Human Development Report.

\section{A Jobless Growth Model Has Failed}

The average unemployment rate reached more than 10 per cent in the advanced countries. The UK jobless rate has reached a new 17 year high. The number of Britons out of work hit the highest level in more than 17 years in November 2011. The Office for National Statistics said the total number of people unemployed using the ILO measure rose 118,000 in the three months to November to 2,685 million, the highest level since August 1994. ${ }^{10}$ 
More than 4.5 lakh American workers may lose their jobs in the near future and almost double that would be jobless in the European countries. "The capitalist system has failed at all levels such as policy, management, inspection, and distribution of the role and responsibility of the financial institutions," said the OECD General Secretary, Mr. Khose Ankhel Gudia, on BBC on 30"th September 2011. Inflation increased at the highest level (especially in food and basic commodities) in all over the world. Unemployment ratio has increased from 10 to 40 per cent everywhere. A jobless growth model is only responsible for increasing poverty, inequality among the society and between the nations, unemployment, and malnutrition due to food unavailability and illiteracy and environment degradation. We find everywhere that job loss and inflation are common phenomena. A top level (22 members' panel) committee on 'Global Sustainability' set-up by the General Secretary of the UN along with the various sections of the societies, are going to discuss the most prime agenda: how to eliminate 'poverty, inequality, unemployment, inflation, and environmental problems,' at the "Rio-plus 20 Conference", to be held in June 2012.

\section{Full Employment Scale Cannot be Achieved under the Capitalist System}

This, in turn, becomes possible through the maintenance of a reserve army of labour whose role is to weaken the trade unions so that they cannot enforce money wage increases even when prices are rising. Full employment under capitalism is impossible for several reasons and this is an important one among them, namely that full employment under capitalism is incompatible with the role of money as a store of value.

But money wages, i.e. the value of labour-power, being sticky within each country is not enough. If the use of the labour-power of a particular country produces goods, which at the money wage prevailing there (in terms of, say, dollars at the going exchange rate), can be sold only at dollar price where nobody wants those goods, then the holders of financial claims over assets in that country will feel "disturbed": the value of their claims vis-a-vis the goods produced in that country may remain stable, but the goods of that country itself will not be worth much in the international market, if they are unsaleable. Goods that are unsaleable, i.e. cannot be converted into money, cannot possibly be representative of the universal equivalent that is money. Not only 
must the money wages of each country therefore be sticky, but they must also be sticky at levels where the country becomes (to use momentarily the terminology and analysis of "mainstream economics") "internationally competitive" at the prevailing exchange rate.

This need not, of course, be the case if the holders of financial claims in that particular country are constrained to keep holding those claims (the only other alternative for them being to hold commodities); but if they can shift from holding claims in that country to holding claims in some other country, i.e. if there is globalisation of finance so that finance can move around freely across countries, then money wages in any country must not only be sticky, they must also have a particular level, corresponding to the exchange rate, at which the country is "internationally competitive".

A moment's reflection however, would show that "international competitiveness" per se means little; a country may be "internationally competitive" by any objective criterion and yet its goods may not sell internationally for a variety of reasons, ranging from prejudice against such goods to lack of familiarity with them. Hence the only index that wealth-holders will look at, for continuing to hold financial claims in a particular country, is whether it runs a persistent balance of payments deficit. If it does, then even if its money wages are sticky they would move elsewhere; but, if it does not, then they would stay on.

But whether a country faces a balance of payments deficit depends not just on its own actions. It depends very crucially upon the state of world demand. A fall in aggregate world demand must mean a fall in the world demand for the products of some countries. This may have nothing to do with their "international competitiveness", and yet they would face a balance of payments problem. For instance, let us suppose that the American government cuts its expenditure which reduces "world demand", and that some officials in the US lose their jobs and incomes as a result; if their incomes were spent each year on a holiday in Greece marked by a visit to the Acropolis, then their income loss would entail a worsening of the Greek balance of payments, which has nothing to do with any loss of "international competitiveness" on the part of Greece. The proposition that "competitiveness" alone determines the state of the balance of payments belongs to the "mainstream" economic theory that assumes, entirely erroneously, that there is never any problem of aggregate demand (and that Say's Law, which Marx had pilloried, holds). 
To make wealth-holders continue to hold claims, say, in Greece, i.e. to prevent a financial outflow, the Greek government, then, will have to take steps to reduce aggregate demand within the Greek economy (which is what financiers are demanding today), so that Greek imports go down and the Greek balance of payments improves. But this not only imposes even greater burdens on the Greek people who are already hit by reduced world demand for their products, burdens in the form of even greater unemployment and reduced consumption, but also compounds the initial decline in world demand, aggravating the world economic crisis.

\section{Biggest Lenders (the USA \& EU) Shucking the World Economy}

Advanced capitalist countries are facing two basic problems such as financial deficit, and public debt which has reached 100 per cent of their GDP. The USA, Greece and Italy are the biggest lenders. Approximately, Italy has taken 1.8 trillion euro which is more than Spain, Portugal, and Ireland. It is more than 126 per cent of the Italian GDP. According to European Banking Authority, Spain has 326 billion euro which has been taken from 90 European banks. The Italian economic growth ratio is only 0.1 per cent and the Italian Government recently announced to cut their government budget, at least 20 billion dollars in 2012 and 25 billion dollars in 2013. As a result of that, 50000 public servants may lose their jobs in the near future. It is clear that workers are paying the heaviest cost for a crisis far beyond their control.

The impact of the crisis will go further than job and income losses, causing the incidence of informal work and working poverty to rise. Young people, migrant and women workers are the most vulnerable to the current downturn and are all faced with considerable difficulties in integrating in today's labour market. This trend stands to be exacerbated by the global crisis and if viable solutions are not found, personal development and future employment prospects are threatened for millions of young people. Compared to adults, youth are almost three times as likely to be unemployed, and although they make up only 24.7 per cent of the total working-age population, youth make up as much as 40.2 per cent of the world's total unemployed.

Investors worldwide have lost confidence in economic leadership, driving markets into a "new danger zone", the head of the World Bank has warned ahead of a crucial meeting that could shape the Euro 
zone's future. In a clear shot across the bows of leaders in Europe and the US, Robert Zoellick said the events of recent weeks had led "many market participants to lose confidence in the economic leadership of some of the key countries". Speaking at a dinner in Sydney, Australia, he added: "I think those events, combined with some of the other fragilities in the nature of recovery, have pushed us into a new danger zone. I don't say those words lightly ... so that policymakers recognize and take it seriously for what it is." Mr Zoellick said that a trend of acting on issues "a day late" had led to a situation where worry "has accumulated and so we're moving from drama to trauma in a lot of the Euro zone countries."

\section{Survey of the Asian Economies}

Asia's economies are set for a tough start to 2012 as both China and India expand at their weakest pace since the tail-end of the global financial crisis in 2009 before rebounding in the second half, a Reuter's poll showed on $19^{\text {th }}$ January 2012. A survey of more than 250 economists across Asia found them slashing growth estimates, a sign that the once roaring region is feeling the heat from higher interest rates and a raging crisis in the Euro zone that is dragging it into recession. But Asia's policymakers, unlike those in the developed world who have chopped interest rates to near zero and are resorting to bond purchases and extraordinary liquidity injections as stimulus, still have ammunition left in their arsenal.

They will act to stave off any sharp declines in growth, with rate cuts expected for India, Australia, Indonesia, Malaysia, the Philippines, Thailand and Vietnam, and fine tuning of policy in the world's second largest economy, China. Asia is somewhat insulated from, but not immune to, the Euro zone debt crisis. With the focus now on how to contain-rather than prevent-an eventual Greek debt default, leaders are racing to stop any contagion that might tip the world back into recession. The IMF is now seeking to more than double its war chest by raising US $\$ 600$ billion to help struggling economies but that plan is already facing stiff resistance from the US and other countries.

China's growth is set to slip to just under nine per cent in 2012 with its renewed softening in price pressures providing officials with the flexibility to favour an even more accommodative policy setting in support of growth. Out of 34 economists polled on China, five thought growth would dip below eight per cent this year (2012), a level many 
consider marks the borderline between a severe slowdown and a mild one. In the Reuters poll conducted three months ago, not a single economist predicted China's growth would fall below eight per cent. ${ }^{11}$

\section{An Alternative to Neo-liberalism}

Is there a need to rethink about the classical Adam Smith's free market, free economy, laissez fair economic philosophy which was implemented by the first world since (the USA's former President Mr. Ronald Reagan and the British Prime Minister Ms. Margret Thatcher) what it called: "Reagan-Thatcher" imperialist driven globalization?

\section{Need to Understand their Two Basic Principles of Capitalism}
> Man is able to control the behaviour of markets, was totally wrong, and
Prices of commodities and factors/resources are determined by the market forces; such as demand and supply forces, was also wrong.

History shows that exploitation of resources at massive levels at the cheapest price on the one hand, and the highest rate of selling their products in the open market on the other hand for profit maximization by the big corporate sectors-led economies were the two basic principles of capitalism that have still been practised from slavery, feudalism, colonialism, capitalism and imperialism.

In a capitalist society, an economic minority (the bourgeoisie) dominates and exploits the working class (proletariat) majority. Marx uncovered the interworking of capitalist exploitation, the specific way in which unpaid labour (surplus value) is extracted from the working class (the labour theory of value), extending and critiquing the work of earlier political economists on value. Although the production process is socialized, ownership remains in the hand of the bourgeoisie. This forms the fundamental contradiction of a capitalist society. Without the elimination of the fetter of the private ownership of the means of production, human society is unable to achieve further development.

The motor of the global economy-developing countries- is slower at the same time as the world's largest economic area-the EU-is in recession and these could feed each other. ${ }^{12}$ According to the World 
Bank, amongst the developing countries, it is only China that has the capacity and will to implement policies to counter this new imminent global economic downturn. No matter whether people accept it or not it is a reality that China has become a business and economic leader today. And that's why the World Bank (including the advanced capitalist world) is looking for China. Why is China stable today? As I read ever-more hyperbolic accounts of the Chinese economy, its impact on global trade, and the spending spree of its newly rich middle classes, I wanted to find out about the men and women who are leading this transformation. I was seeking the people behind the country's explosive economic growth-the top entrepreneurs, and these top entrepreneurs are fully engaged with more than 42 million SMEs sectors which are friendly interlinked with the biggest MNCs. They are the ones building world-beating companies, producing the cheapest commodities than others, leading China's export success and creating new jobs by the million. China replacing the G-7 in the wake of the economic crisis, through sharing their own science and technology to improve and transform in agriculture and industrial sectors in Africa, Latin America, and Asia, and, through using FDI/ investment in all over the world, willing to buy the USA and the EU government's debt, emerged as a 'new business leader'. China comes in for detailed analysis by examining the process of reforms initiated since 1978. While the country made tremendous strides in development in the last three decades, the process also brought to the fore the "adverse changes in production relations" and, therefore, in social relations in China today. How successfully these contradictions are dealt with and how they are resolved will determine the future course in China.

Karl Marx himself had a soft spot for entrepreneurs. In Das Kapital he asserted that workers were exploited by capitalists who profited from the added value of their labour. But he argued entrepreneurs, although still capitalists, added their own value - through their fresh ideas and ability to seize opportunities. Entrepreneurs, at least the good ones, were benign capitalists, said Marx. I wanted to get behind the corporate announcements and the carefully managed public appearances to see how China's super-rich actually live, to hear what they really think and to try to understand why they had risen to the top of the society, with their 1.3 billion fellow-countrymen and women. What do they feel about the vast mass of China's population? How are they coping with their wealth? What are their plans for the future? 
No doubt, Chinese economy is also facing some problems (especially the Chinese exports sector). But it is true that China is able to maintain its economic growth successfully in the upward direction with sustainable development with the dominant socialist mode of production. China is willing to buy the whole American and European debts. These advanced capitalist countries are looking to China to reduce the USA's and EU's burden, and is invited openly at various occasions. Top economic and political leaders are agreed that it is China who is able to invest in their various sectors today, and that is creating new reverse development in economic history.

The capitalist mode of production, of course, creates wealth but it also creates inequality, poverty and unemployment. In other words, it creates wealth at the cost of equity. It might help the corporatesbourgeoisie but hurt current generations. The current global economic depression which started with the housing bubble in the U.S. in 2006, and along with the sovereign debt crisis in Europe, now entered a dangerous zone all over the world, which is likely to be deeper and longer-lasting than the great depression of the 1930s because the countries do not have the fiscal and monetary space to stimulate the global economy. The financial system of the largest economic bloc in the world is threatened by a fiscal and financial crisis that has so far eluded policy-makers' efforts to contain it. John Maynard Keynes had advocated during the post-1930's Great Depression "Active State intervention is the only manner in which capitalism could achieve full employment through public investments." This, according to him, was the only way to save capitalism and, thus, protect it from the imminent takeover of socialism.

During the last two decades of the end of the Cold War, when the international correlation of forces moved in favour of imperialism following the dismantling of the USSR and the socialist countries in Eastern Europe, imperialism unleashed an all-round offensive political, economic, military, cultural and ideological - to strengthen its global hegemony.

The emergence of international finance capital following unprecedented huge levels of capital accumulation unleashed a new re-ordering of the world economic order. This is to further facilitate profit maximization - the raison d'tre of capitalism. By virtually drawing all the countries of the world into its vortex, imperialist globalization under the dictates of international finance capital 
pressurizes all countries to remove all restrictions for the flow of this capital in its pursuit of profit maximization. The consequent package of economic reforms include financial liberalization, the prising open of the markets of independent countries through trade liberalization, the privatization of State-owned assets, the conversion of public utilities (electricity, water, sanitation, civic amenities, etc) and services (education, health, etc) into areas of profit generation. Neo-liberalism is the ideological and theoretical construct that defines such reforms.

Such a process of gigantic accumulation under the leadership of international finance capital is generating deep crisis imposing unprecedented burdens on the vast majority of the world's population. In the efforts to resolve one crisis, the seeds of a more intense crisis are being sown. The global financial meltdown caused by the sub-prime credit crisis was sought to be overcome through humongous bailout packages to resurrect those very financial giants who caused the crisis in the first place. This resulted in converting corporate bankruptcies into sovereign bankruptcies. This, in turn, is being sought to be solved through the reduction in government expenditures by imposing 'austerity measures' and drastically reducing social sector expenditures that are mounting further economic onslaughts on the people. This, in turn, is leading to a further contraction of the purchasing power in the hands of the people, sowing the seeds of a deeper crisis of double-dip global recession that is, today, looming large. It is clear that the magnitude of global economy has entered a dangerous phase. It is not simply a financial crisis but a full-flagged global capitalist crisis as the ensuing global downturn is likely to be deeper and longer-lasting than the recession of the 1930s because countries do not have the fiscal and monetary space to stimulate the global economy.

The cause of the problem was located in the fundamental defect of the free market system regarding its capacity to distinguish between "enterprise" and "speculation" and hence, in its tendency to become dominated by speculators, interested not in the long-term yield assets but only in the short-term appreciation in asset values. The crisis was not the result of some "mistakes" or "aberrations". It was just a failure of the system.

Capitalism has a tendency to even ignore the boldest of writings on the wall. Marx had once said that capitalism "has conjured up such gigantic means of production and of exchange, it is like the sorcerer who is no longer able to control the powers of the nether world whom 
he has called up by his spells." The crisis is systemic. It is not because of the greed or avarice of individuals. The only true liberation for humanity can come with the overthrow of this system.

The current capitalist crisis has ended talk of the triumph of capitalism. The struggles and movements of the people in Europe can bring about a substantial change only when a strong political alternative in the form of the Left forces is built up. In Latin America, the Left has maintained its advance. A number of countries with Left governments have rejected the neo-liberal model and are implementing policies which are an alternative to neo-liberalism. Increasingly it is becoming clear that the only alternative to the exploitative neo-liberal capitalism is socialism.

\section{End Notes}

1 Prabhakar. A. C. (2011). BRICS Economy: The new emerging markets of Asia, Eastern Europe, Africa and Latin America (p. 38). Lambert, Germany.

2 Prabhakar. A. C. (2011). The great depression of the twenty first century: An evaluation of the current trends in the world economy (p. 18). Lambert, Germany.

Ibid.

4 Source: BBC Hindi News on 17 th April, 2011.

5 Source: BBC Hindi News on 17 ${ }^{\text {th }}$ April, 2011.

$6 \quad$ World Bank. (2010). Global economic prospects: Fiscal headwinds and recovery.

7 Source: The Financial Times, London.

8 Source: International Conference on Trade, Investment, and Production Function in Asia organized by Nottingham University Malaysia, Kuala Lumpur in January 2012.

9 World Economic Situation and Prospects (WESP) is a joint product of the Department of Economics and Social Affairs, the United Nations Conference on Trade and Development and the five United Nations regional commissions. It provides an overview of recent global economic performance and short-term prospects for the world economy and of some key global economic policies and development issues. One of its purposes is to serve as a point of reference for discussions on economics, social and related issues taking place in various United Nations entities during the year. Source: Reuters.

12 Source: Reuters.

13 The Head of the Macro Economics of the World Bank said on Wednesday, January 18, reports the Financial Times, London. 
IJMS 20 (1), 109-163 (2013)

\section{References}

Marx, K. (1992). Capital: A critique of political economy (Volume 1). New York: Penguin.

Prabhakar, A. C. (2010). Globalisation \& development strategy: The new dynamics of world economy. Germany: Lambert Academic Publishing.

Prabhakar, A. C. (2010). Advanced macroeconomics. Germany: Lambert Academic Publishing.

Prabhakar, A. C. (2010). Globalisation \& Africa: A rethink their development strategy. Germany: Lambert Academic Publishing.

Prabhakar, A. C. (2011). Globalisation, trade \& development: Theoretical $\mathcal{E}$ Empirical Investigation. Germany: Lambert Academic Publishing.

Prabhakar, A. C. (2011). The great depression of the twenty first century: An evaluation of the current trends in the world economy. Germany: Lambert Academic Publishing.

Prabhakar, A .C. (2011). Agricultural transformation \& rural development: Lessons from Chinese experiences. Germany: Lambert Academic Publishing.

Prabhakar, A. C. (2011). BRICS economy: The emerging markets of Asia, Eastern Europe, Africa and Latin America. Germany: Lambert Academic Publishing.

Sharma, A. N. (2005). Agrarian relations and socio-economic change in Bihar. Economic and Political Weekly, March 05, pp. 960-972.

Wilson, K. (1999). Patterns of accumulation and struggles of rural labour: Some aspects of Agrarian change in central Bihar. Journal of Peasant Studies, 26(2-3), 316-354. 



\title{
CONCEPTUALISATION OF NATION BRAND IMAGE
}

\author{
BINTANG HANDAYANI \\ BASRI RASHID \\ School of Tourism, Hospitality and Environmental Studies \\ Universiti Utara Malaysia
}

\begin{abstract}
This paper examines the nation brand image notion. Literature review is employed as the method to develop the conceptual model. This paper suggests that the multifaceted nature of a nation can be covered in the nation brand image. In addition, the theoretical relationship between national brand identity, national identity, tourism brand and nation brand image and is also explored. This paper eventually proposes a conceptual model of nation brand image and suggests that future research include the multi elements of national brand identity and national identity as the components of nation brand image.
\end{abstract}

Keywords: Conceptual model, nation brand image.

\section{Introduction}

Giving nation a brand is considered not enough to be a market leader and have a strong positioning. Referring to the theory of branding, one of the ways to be a market leader and have strong positioning is not only by having a brand (Keller, 2003). Beyond that, to be a market leader and have strong positioning requires brand image. This paper provides an insight on the nation brand image notion. In doing so, the first section discusses the paradox of nation brand. It moves on to the second section that critically reviews the brand image and nation brand image notion; followed by a discussion on nation brand image and tourism brand. The discussion reviews the perspective of giving nation a brand image through national identity as nation brand differentiation. In conclusion, a definition and a conceptual model are offered as an extension of previous studies (Olins, 1999; O'Shaughnessy \& O'Shaughnessy, 2000; Kotler \& Gertner, 2002; Gilmore, 2002; Anholt, 2002, 2007; Dinie, 2008; Fan, 2010; Kaneva, 2011). 


\section{Nation Brand Studies}

The idea of giving nation a brand is intriguing. Nation brand is acknowledged as the growing sub-filed of place marketing (e.g. Anholt, 2002, 2007; Gilmore, 2002; Kotler \& Gertner, 2002; Olins, 1999; and Papadopoulos \& Heslop, 2002). According to literature, between 1950 and 2002, 766 books and articles by 789 authors have been published on the subject of place marketing (a special issue of the Journal of Brand Management, 2002). The number implies that nation brand is a growing subject of interest among scholars in brand management.

In general, most of the studies highlight nation brand as part of the national strategy to build positive image and reputation (Anholt, 2002; 2007; Fan, 2006). Subsequently, nation brand expands its scope by not only aiming to build positive a image, reputation and gain more international market shares but also strengthening a country is position at the international stage. However, the nation brand notion seems to be considered vague due to unsettled debates on the nation brand existence. For instance, Fan (2006) argues that a nation has brand image with or without a branding technique, while several authors keep on suggesting that there is a need for a nation to be branded (e.g. Anholt, 2002; 2007; Gilmore, 2002; Kotler \& Gertner, 2002; Olins, 1999; Keneva, 2011).

Nevertheless, the nation brand concept can be regarded as being in the infancy stage. This is partly because the place branding and its sub-field (nation branding) is considered a minority in every involved discipline and field of studies that interact within its notion (Kaneva, 2011). As an infant notion and a minority in related fields and disciplines, it is deemed appropriate to conduct theoretical research to enrich this notion (Kaneva, 2011; Fan, 2010).

The fundamental idea is to expand the recommendations of previous studies which suggest that the nation brand issue should be discussed from various angles and perspectives. In this sense, it is argued that nation brand is not only about developing attractive places for tourists, foreign students, foreign direct investment (FDI), talented/ skilful people and business transactions but also positioning a nation as a market leader in a certain category (Olins, 1999; O'Shaughnessy \& O'Shaughnessy, 2000; Kotler \& Gertner, 2002; Gilmore, 2002; Anholt, 2002; 2007; Dinie, 2008). 
One of the issues that past studies highlighted is the multifaceted nature that a nation is attached with (Kaneva, 2011; Dinnie, 2008; Fan, 2006). It implies the difficulties in giving a single brand to a nation brand which denotes a single image (or single message for different audiences in different countries). It is noted countries have put lots of energy; capital and time to create a nation brand by only adding an adjective before or after the country's name. By highlighting what they have and how fantastic the country is (and/or its resources are). The tendency of most governments that only focus in creating bombastic campaigns (which are claimed as nation brands) implies confusion between developing a nation brand and developing a tourism brand. This phenomenon generates questions such as what is the distinction between these constructs. This subsequently leads to the issues on how to manage national dimensions (which are considered as a country's products) that are multifaceted (Dinnie, 2008; Fan, 2006) and how can literature support the idea of giving a nation a brand. Unfortunately, there seems to be only limited study on differentiating the constructs of nation brand and tourism brand.

Aside from that, nation brand is also associated with national identity. It is used as a national brand identity in the initial stage of treating a nation as a brand. It functions as core essence to differentiate a nation over others (Fan, 2010; Kaneva, 2011, Fan, 2010; Kotler \& Gertner, 2002; O'Shaughnessy \& O'Shaughnessy, 2000; Anholt, 2002; 2007; Gilmore, 2002; Olins, 1999). However, these issues of unsettled debate, the vague notion of nation brand and the role of national identity in giving nation a brand are considered to have less wellfounded studies.

Borrowing Keller's theory brand image (2003), this study offers an alternative for giving a nation a brand. In this sense, instead of developing a nation brand (which is against the multifaceted nature of a nation as a big entity), it is wise to develop a nation brand image.

Dinnie's (2008) conceptualization of a nation-brand identity and image has initially indicated the nation brand image notion, unfortunately, there seems to be limited study clarifying the definition of a nation brand image. Moreover, past studies merely provide conceptions about the variables which only emphasise how nation branding gives a nation a brand (not giving a nation a brand image). Due to that matter, this paper moves to discuss nation brand image and its conceptualization. 


\section{Paradox of Brand Image}

One of the arguments that needed to revisit the nation brand notion is when Fan (2006) specifically argues that nation has a brand image with or without a nation branding technique. Secondly, most of the studies focus on how to brand a nation without specifically defining the clear idea of the notion. If the idea of giving a nation a brand is argued for developing a nation's image and reputation, thus the philosophy of giving a nation a brand by merely creating a bombastic campaign that simply involves advertising the perspective and Public Relations (PR) technique. In this sense, it is contrary to the nation brand image which Kaneva (2011) and Fan (2006) argue that a nation brand image is not only aimed to improve a nation's image and reputation but it also involves nationhood (national identity).

The phenomenon of creating a bombastic campaign can be seen from what most governments have done to promote their countries to the world. Regardless of that effort, some governments are unsatisfied with the result of exposure through the bombastic campaign. This is due to the fact that there is no significant improvement on positioning and the number of tourists' arrival to a country (Anholt, 2006). Implicitly, there is a gap of interpreting the idea of giving a nation a brand.

While several authors argue that a nation brand exists without a branding technique, some authors assert that giving a nation a brand is important due to globalization (Kotler \& Gertner, 2002; O'Shaughnessy \& O'Shaughnessy, 2000). However, Fan's (2006) argument that the existence of a nation brand is naturally constructed can be considered in line with the proposition that nations historically have branded themselves through icons and symbols such as flags, military uniforms, currencies, anthems and ideology due to regime changes or ideology changes and stereotypes (Dinnie, 2008; Fan, 2006; Kotler \& Gertner, 2002; O'Shaughnessy \& O'Shaughnessy, 2000).

Thirdly, even though recent studies mention national identity in the nation brand notion (Fan, 2010; Kaneva, 2011) which indicate that other variables involved in strengthening the nation brand notion, still it seems debatable due to the difficulty in giving a nation a brand (Zenker, 2011). Those who disagree have suggested a new term such as place brand (Zenker \& Braun, 2010). In this sense, the nation brand notion is being questioned due to insufficient explanation of its notion and a lack of literature support. 
On the contrary, the idea of a nation brand image is rather plausible and possible to be implemented (refer to the following discussion of brand image and nation brand images). Although, Dinnie (2008) implicitly has conceptualized the idea of a nation brand image, the idea may require further clarification. According to Dinnie (2008) a nation brand image is derived from a nation brand identity which must be executed by proper key communicators. In addition, a nation brand must address the diverse range of audiences and denote the need to seek for a certain identity in order to develop a nation brand image. However, the conceptual model did not define (or differentiate) the concepts of the notion clearly which generates confusion about a nation brand and a nation brand image notion. Unfortunately, studies that try to clarify the concept of a nation brand and a nation brand image notion seems to be very limited. Hence, the following section strives to clarify concepts and the notion of nation brand and nation brand image.

\section{Brand Image and Nation Brand Image}

Kotler and Gertner (2002) argue that the nation brand notion is derived from strategic image management (SIM) which is important to attract international audiences. Nation brand is defined as a total perception of international audiences which emerged as the overall image of a nation (Fan, 2010).

On the other hand, based on the traditional branding theory, the nation brand image notion can be derived from strategic brand management (SBM) which Keller (2003) points out as part of brand knowledge of the segmented target audiences. Keller (2003) argues that brand image is closely related to the level of familiarisation of target audiences in associating the products offerings and influences the purchase decision. Brand image is defined as everything that people associate with the product offering (Newman, 1957; Keller, 2003). It generates types of brand associations, favourability of brand associations, and strength of brand associations and uniqueness of brand associations (Keller, 2003).

The brand associations refer to its symbolic attributes, level of quality, the profile of the company and functions which can be seen from product related and non-product related that characterize the identity. Positive brand associations indicate conditions where people tend to 
recall and recognize the brand as if it is the product itself and tend to become a first choice in the market. It signifies a positive brand image (Keller, 2003).

A positive brand image stimulates consumers' intention or willingness to purchase (Hsieh et al., 2004). It influences the buying decision and potentially becomes a market leader in a certain category, while negative brand image is not. It is due to the belief that people not only purchase the physical functions of products or services, but also the symbolic meanings associated with the brand name which are eventually linked to prestige. This implies the affective phase of the attitude theory. It highlights the proposition of the accumulative level of cognitive and affective on consumers' future action (conative). Consequently, the brand image of the product offerings not only becomes assets of the company but also shapes the prestige of the consumers.

Prestige of consumers is developed from types, favourability, strength and uniqueness of the brand associations. These brand associations imply not only the consumers' cognitive but also grabs the consumers' affective. In this sense, the objective of giving a product a brand image is not only to build brand awareness (through symbolic-oriented process) but also to generate a positive brand image (through types, favourability, strength and uniqueness of the brand associations) in the consumers' mind.

Similarly, this is applicable to a nation. The idea of a nation-brand image is not only to build nation-brand awareness (refers to the nation's image) but also to foster a positive nation-brand image (refers to reputation, positioning which leads to position as a market leader). Johansson (1993) Agrawal and Kamakura (1999) argue that a favourable image that is attached to the place (which refers to nation) can be a competitive advantage to win international markets. It is also argued that besides becoming a brand name, a country's name can also be the product itself. This is due to competition to attract tourists, factories, businesses, the faces (very important people), foreign students and talented skilful people (Kotler \& Gertner, 2002). These international target audiences are also similar to the target audiences of any other product offerings which will purchase goods or services not only based on the physical function but also the prestige of the brand image. 
In general, a country product offering can be grouped as the national dimensions which are managed under a country's name as a brand. National dimensions are classified into tourism, export, government, culture, people, investment and immigration (Anholt, 2002; 2007). It signifies social-cultural, economics, and politics (Kotler \& Gertner, 2002; O'Shaughnessy \& O'Shaughnessy, 2000; Dinnie, 2008). Due to this multifaceted entity of a nation, nation brand is attached with multiple images which could be positive or negative, thus, making it difficult to give a nation a brand. On the contrary, the brand-image theory states that to have a brand image requires brand associations. Brand associations denote multifaceted images which can be perceived by different audiences. In this sense, conceptualizing nation brand image is possible.

According to the brand knowledge theory, brand image is closely related to the level of familiarisation of the target audiences (Keller, 2003). Thus giving nation a brand image is related to national activities that are performed through national dimensions. It aims to make international audiences familiar and be able to recognize a country's national dimensions and influence the buying decision so that it can be a market leader in a certain category. In this sense, the idea of developing the nation brand associations is to design the nation's images that possess multifaceted nature. It is done based on the selfperception (which is considered as national identity) and desired images (visionary perception) that a nation wants to be perceived by international audiences.

Particularly, self-perception and desired images are part of the nation image perspectives which denote the process of the nation branding formation. In other words, nation brand image is developed through key perspectives of nation image (Brown et al., 2006; Fan, 2010), while nation brand merely involves the actual image (Fan, 2006). In other words, it is not being controlled by the producer-based on the stereotype.

In general, the key perspective in nation image consists of constructs such as identity, image and reputation that refer to mental associations that generate a frame of experiences and a frame of references of the international audiences. Identity is defined as self-belief of the characteristics that the entity has. While image is collection of identity that is projected to others, reputation is the feedback received from others about the images that is projected (Whetten \& Mackey, 2002; Fan, 2010). 
The key perspectives in nation image illustrates the need of identifying self-perception of identity which is defined as a question: 'who are we as a nation?'. This initial phase leads to what reference points think about us as a nation. The third one is related to the idea of constructing the nation image which implies the beginning of a nation-brand image development. This constructed image is related to a question of what we believe our image is in front of the world. Subsequently, the constructed image builds the actual image that shapes reputation and stereotype. In this stage, the government of a country analyses how the nation image is actually perceived by others. The fifth key perspective in nation image is the projected image which is defined as the constructed image that does not reflect the reality of the nation which leads to the need to form the desired image (point number six of the key perspectives). The desired image needs to be developed in order to distribute the visionary self-perception that a nation would like other nations to hold about it in the future.

Unlike the nation-brand notion which is related only to the actual image that external (outsiders) perceive, nation-brand image is related to both actual images that external (outsiders) and internal (insiders) perceive about nation images. In this case, the conceptualization model that is offered by past studies which argued the need of a nation-brand identity is confirmed due to the philosophy of the nation-brand image notion (Dinnie, 2008; Fan, 2010; Kaneva, 2011). It denotes nation brand image as a construction process of multifaceted images of the nation based on the key perspectives in nation image that Fan (2010) offered.

Therefore, nation-brand image is defined as the total collection of a nation's multifaceted images that are associated with a country's national dimensions and activities which are managed by a country's government based on actual image, national identity and desired future image to be perceived by international audiences.

\section{Nation Brand Image and Tourism Brand}

To date, studies about nation-brand image are associated with the country of origin (export dimension), public diplomacy (Roth \& Romeo, 1992; Heslop \& Papadopoulos, 1993; Pappu et al., 2007; Szondi, 2008) and cultural focus (Morgan \& Pritchard, 2002). The philosophical aim is giving national products a brand. For instance, textile or Moslem clothes which are labelled as made in Indonesia 
and being exported implies the country of origin notion which also implies that Indonesia is the biggest Moslem country in the world. That analogy signifies not only the product related to a country being offered to international audiences but also denotes the belief structure (part of national identity elements) of Indonesia as a nation.

On the other hand, a public diplomacy study focuses building hard and soft power (a country's power in influencing or forcing political, financial, and social activities) at the regional or international stage (Szondi, 2008; Fan, 2008). In this case, the public diplomacy study denotes the national system and ideology that countries chose also implies the way they projected themselves regarding international issues.

The cultural study focuses on national heritage and cultural homogeneity which generates national identity as well. Most of this study is used to build the tourism dimension as one of the national products that influence international audiences' perception; e.g. the Malay, Indian and Chinese races represent countries in South East Asia which mostly tourism attractions as national products in that region.

Many studies that dominated the nation-brand image notion have brought confusion. The most notable one is the confusion of between identifying nation-brand image and tourism-brand notions. Past studies acknowledged that the tendency of most governments in creating bombastic campaigns by adding adjectives to the name of the country is not considered as nation brand (Dinnie, 2012; Fan, 2006) but more to tourism brand which most governments have a part in taking tourism as a national industry.

As it has been defined nation brand is the total perception of international audiences about a country. Nation brand exists with or without nation-branding notion due to stereotypes. Stereotype produces prejudice, and unreasonable judgments based on one's own group (Lippman, 1922 cited in Fan, 2008). On the other hand, nationbrand image notion focuses on developing (designing) national brand associations in order to increase international audiences' familiarisation towards national dimensions that represent the sociocultural, economic, and political activities of a country. Nation brand denotes symbolic oriented which refers to national identity. For instance, Indonesia is nation brand is Bhineka Tunggal Ika. Bhineka Tungal Ika represents the pluralistic characteristic of Indonesia and its cultural attachment as a nation. For nation-brand image, the focus 
is managing brand associations which can be derived from endorsed brands such as the national tourism brand or the country of origin (export dimension).

The distinction between these constructs refers to the classification of national brand identity which nation brand denotes the umbrella brand that covers overall national identities. National tourism brand signifies the tourism national brand identity (endorsed brand) which is well-known as a subject of destination-branding notion (Morgan \& Pritchard, 2002). Tourism national brand identity (endorsed brand) is managed as one of the national dimensions (similar to the country of origin notion which generally links with export dimension). However, tourism national brand identity is considered relatively close to nation-brand image notion. It is due to proposition that the nationbrand image notion is designing nation brand associations which are derived from national identity (self-perception which denotes national profile based on socio-cultural, political and economic) which most countries interpret nation as people and nation as culture (Fan, 2006). For instance, British imply nation as people and as culture. Therefore, it is sufficient to say that national-tourism brand is part of the nationbrand image notion.

\section{Why Giving Nation a Brand Image is Important?}

As mentioned in the introductory section, the critical question of giving the nation a brand is how to brand the multifaceted nature of the nation. In this case, giving the nation a brand is considered difficult but it is possible. The overall nation images which are too nebulous can be solved by applying the strategic brand-image management approach. In this sense, the multifaceted nature of the nation image is managed through strong associations to establish affect- driven, while knowledge of the actual choice processes used can be a guide to the likely influence of the imaginary versus reputational capital (O'Shaughnessy \& O'Shaughnessy, 2000; Fan, 2008).

Fan (2006) argues that stated nation brand exists with or without nation branding and that nation brand focuses on the actual image that is held in the consumers' mind with or without branding techniques. It tends to be a symbolic oriented process that is perceived by outsiders. In this case, it becomes the outsiders' perception that is based on symbols such as place, geography, flag, ideology \& systems, history of colonization, language, socio-cultural, political and economic activities. 
Unlike nation brand, the nation-brand image notion is beyond nation actual images. It is considered as constructed images that are developed by the government based on the desired image (Gioia et al., 2000; Fan, 2008), national identity, references point perception, and projected image. For instance, recently Australia put education as the umbrella brand and added the Indonesia in language (Bahasa Indonesia) as a subject to be studied by students. The United Kingdom on the other hand implemented philosophy to be studied by children in schools. This implied the awareness of the UK and Australia as part of the regional (and/or global) community. These countries show what they are for and how relevant they are for both internal and external publics. Therefore, Asians tend to have the association (perceived images) that the UK and Australia are the destinations for studying.

In this sense, the distinction between nation brand and nationbrand image is in the construction process of applying the branding techniques. In other words, nation brand focusses on symbolicoriented on a country's name as identity and let the image perceived by the outsiders (which normally according to stereotypes are, frame of experiences and frame of references). It means, there is no further effort by the producer (the government of a country) to control the brand (the nation's image). On the other hand, nation-brand image is beyond that. Nation-brand image highlights the brand associations that are needed to be exposed in order to achieve the nation-brand images based on their identity (self-perception) and desired future image (positioning) that a nation wants outsiders to perceive. Though, both applied the nation-branding notion, the main objective of the nation-brand image is to be the first choice which at the end is expected to be a market leader in a certain category.

In this sense, the theory of brand image says that the problem of a nation as a multifaceted entity can be solved by instead of giving the nation a brand, it is better to develop nation-brand image (Keller, 2003). With this perspective, a multifaceted nature of the nation can be useful due to the idea that brand image is developed by producing brand associations (which aims to get strong positioning in the market). Hence the multifaceted nature of a nation is not dismissed.

Having that perspective, developing nation-brand associations denotes multiple images which can be perceived as positive or negative according to its types, favourability, strength, and uniqueness. In general, these images refer to the place-geography, natural resources, tourist attractions, people-races, ethnic groups, 
history, culture, languages, political \& economic systems, social institutions, infrastructure, famous people-faces, pictures or images (Fan, 2006). These entities that are attached with a nation can be categorised into product-related and non-product-related. In short, it is sufficient to note that instead of building nation brand (which is considered difficult to be developed), it is better to shift the nation brand effort into nation-brand images notion.

By having nation-brand images, a multifaceted nature of the nation as a large entity can be accommodated. This means, Keller's theory of brand image can be used to settle the problematic notion of nation brand. Keller's theory of brand image basically emphasis the idea of developing brand associations which can be derived from types of product-related and non-product-related. In this case, the national dimensions that are classified into tourism, export, government, culture, people, and investment and immigration can be productrelated and non-product-related depending on which dimension is selected to be the umbrella brand. Therefore, it is vital for a country to have nation-brand image than only having a nation brand. As for brand differentiation in nation context, national identity comes to play. National identity which is defined as self-perception of a nation is considered as national-brand identity in nation-branding notion which aims to build nation-brand image (Fan, 2010).

\section{National Identity and Nation Brand Identity}

Studies about national identity in conjunction with globalization and the idea of giving a nation a brand are mostly done from the international marketing perspective (Kotler \& Gertner, 2002; O' Shaughnessy \& O' Shaughnessy, 2000). Although, empirical studies that examine the relationship between national identity and nationbrand image variables seem to be very limited, several studies mentioned national identity as the self- perception of a country which denotes them as nations (Fan, 2006, 2008; 2010: Dinnie, 2008; Kaneva, 2011). These studies indicate that national identity is the essence of nation brand.

The distinction between national identity and nation brand identity is correlated but has different meanings. It is argued that national identity is relatively close to culture. It denotes how the 'sense of culture' generates the characteristics of a nation (Keilor \& Hult, 1999) which generate the central, enduring, and distinctive (CED). CED signifies the past, present, and future of the people who live in certain 
country as a nation (Fan, 2010). In this sense, nation refers to people who are tied up and live together in certain geographical land, ruled by a government and share similar backgrounds, race, languages, history, heritage, beliefs, ideology, and systems, (Longman Dictionary of Contemporary English, 1995; Oxford Dictionary, 2005). National identity connects insiders to have a sense of belonging (emotional tie) as part of a large group called a nation (Fan, 2006).

Several prominent authors from place marketing and nation banding defined national identity as the self-perception of a nation which can be used as the core essence to differentiate a nation over others and it can be used as the predictor of nation-branding notion (Kaveva, 2011, Fan, 2010; Kotler \& Gertner, 2002; O'Shaughnessy \& O'Shaughnessy, 2000; Anholt, 2002; 2007; Gilmore, 2002; Olins, 1999). Thus, national identity refers to the overall unique characteristics (the people and the culture) of a nation which differentiate a nation over others.

The elements of national identity have been developed by Keilor and Hult (1999). They classified it into cultural homogeneity, belief structure, national heritage and ethnocentrism. Belief structure is identified as a collection of the religions or cults of a country, whereas cultural homogeneity implies the number of subcultures that have counter and become the strengths of national identity. Belief structure that implies that in a dominant religion held by the majority of the population generates a label on a nation because it is attached with people is beliefs that are being practiced daily. For instance, the Middle East countries are known as Islamic countries because they embrace Islam. On the other hand, cultural homogeneity is generated from the number of subcultures and becomes the strengths of national identity. Normally, cultural homogeneity builds a countryimage label on a nation from the attributes such as traditional clothes, foods, languages, sub-cultures that merge into character that differentiates over others. Aside from that, the important element that also influences national identity is national heritage. It is related to the history of colonialization which produces different national identities to every nation. For instance, the label of "commonwealth" on countries that are being colonized by the British will adopt and adapt the British system. The British system implies the identity of a nation. The last element is ethnocentrism. It is defined as a cultural evaluation and its attributions are based on their own cultural perspectives as the baseline criteria. Ethnocentrism is included in national identity specifically to examine the consumer behaviour setting which possibly effects product choices (Samice, 1994 cited in Keillor \& Hunt, 1999). 
On the other hand, national brand identity is defined as a specific set of associations that brand strategists seek and created in order to develop the nation as a brand for a country (Fan, 2010). In this sense, national-brand identity is derived from tangible aspects (such as natural beauty, historical sites, culture, races, ethnic groups, infrastructure, etc.) and less tangible aspects that refer to behaviour of the people, culture, values and mission (Wood, 2006). In other words, national brand identity is a symbolic-oriented branding that highlights the multifaceted nature that is attached with a nation. It is considered something that is important to be perceived by both insiders and outsiders. Explicitly, it can be seen from one of national dimensions that are selected to be exposed as an umbrella brand (Dinnie, 2008; Anholt, 2002; 2007).

In most cases, tourism has been the most common dimension that is selected by governments to be national-brand identity. It is due to the fact that tourism is attached with people, governmental systems \& ideology, socio-culture, economics, and political activities of a country (Leiper, 1990). Hence, tourism reflects the characteristics of a nation. Tourism as one of the national dimensions is beneficial for the public of a country (insiders and outsiders). For the insiders, national identity (self-perception) and national-brand identity (for instance, tourism dimension) used to tie up and generate nationalism, while for outsiders, national identity and national brand identity are used as short cut of international audiences' purchase decision-making. Therefore, the relationship between national identity and nationbrand image can be summarized as shown in the below.

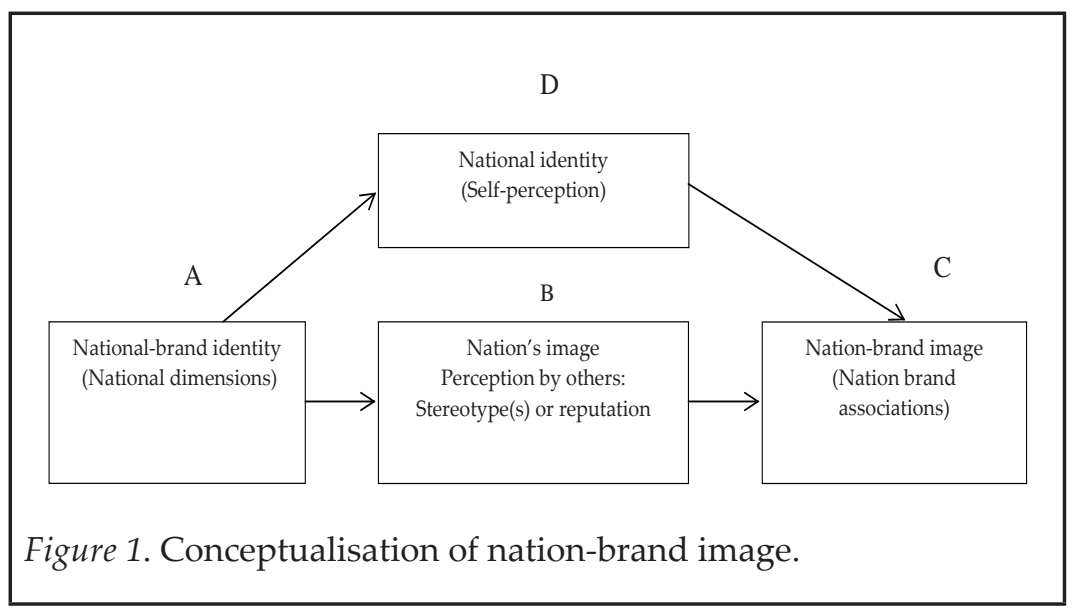


The figure implies direct and indirect relationship between nationalbrand identity and nation-brand image. In this figure, national identity is used as the core essence to formulate nation-brand associations (Keller, 2003). In general it is treated as a mediator variable. The direct flow of the proposed model (A-B-C) indicates nation-brand image. The relationship between A and B shows the argument that a nation's image is defined by outsiders which are influenced through direct and personal experiences, stereotype, media exposure, while indirect flow (A-D-C) denotes nation-brand image notion which Fan (2006, 2010) and Kaneva (2011) highlighted about culture and people as the focus in nation branding. Based on the above discussion, this paper suggests that the essence to build the national-brand association is to implement the cultural and people-orientated approach.

\section{Conclusion}

Nation brand perspective implies a country's name as a brand which covers national dimensions (for instance tourism, export, and etc.) that are managed by the government at the international stage. It refers to the current and actual image (external perception) held in the international audiences' minds. Considering the philosophy of giving a nation a brand image is rather different with nation brand, hence the issue goes on national dimensions as the product-offering of a country that represents national identity; not only focuses on a symbolic-oriented effort and an effort of developing a single image. This is due to the fact that nation brand is a process of managing the images of a country as a nation which aims to build an image and reputation, while nation-brand image notion is beyond that.

Nation-brand image notion is not only to produce brand awareness but also to produce brand associations based on selected national dimensions as product-offering to reach the strong positioning as first choice (market leader in a certain category). The distinction between nation brand and nation-brand image notion is generally due to the key perspective of images conception. Images in a nation brand are the actual images (outsiders perception) which are derived from stereotypes or reputation that are perceived by international audiences. However, nation-brand image is developed not only based on the actual image (reputation or stereotypes) that are perceived by others (references point/significant others) but also from the desired image of a nation that projects national identity (selfperception of a country). 
The biggest challenge on how to communicate a single image (refers to nation brand) to different audience in different countries is countered by applying the nation brand image notion. In this sense, instead of developing a nation brand (which aims to develop a single image), it is wise for a country to have a nation-brand image in order not to dismis the multifacets of a nation. This could be done through the national endorsed brands which are derived from dimensions such as from tourism, export, inward investment, government, talent attraction and sport (Dinnie, 2008).

The distinctions among nation brand, nation-brand image and tourism brand also have been discussed. The three constructs have different meanings but are correlated to each other. Nation brand exists based on stereotype and reputation, while nation brand image constructs images through managing national brand identity (which could be more than one and refers to national dimensions as the product-offering of a country). In this sense, nation brand and nationbrand image notions are considered as an umbrella brand. On the other hand, tourism brand is considered as an endorsed brand which is relatively close to the nation-brand image due to culture and people as the focus of the notion which is argued as the dimension that most influences a nation 's image (Brooks, 2004; Dinnie, 2012). Therefore, tourism brand is foreseen as the most potentially national dimension to represent the nation-brand image.

In order to achieve brand differentiation and to reach strong positioning, the national identity concept comes to play. National identity provides the overall unique characteristics (the people and the culture) of a nation which differentiate it from others. In this case, national identity implies the central, enduring and distinctive (CED) characteristics of its people, culture, systems, beliefs, and all related characteristics which make them to be called a nation.

\section{Limitation and Recommendation for Further Research}

Although this paper provides evidence from literature about the relevancy for a nation to adopt the concepts of nation brand, nationbrand image, national identity and nation-brand identity, it is more on the theoretical nature. Hence it would be more meaningful if future research could take up the proposed framework and explore the possibility to empirically test the framework. This would clarify the robustness of the model and issues of vagueness of these concepts. 


\section{References}

Agrawal, J., \& Kamakura, W. A. (1999). Country of origin: A competitive advantage? International Journal of Research in Marketing, 16(4), 255-267.

Anholt, S. (2000). The nation as brand. Accross the board, 37(10), 22-27. Anholt, S. (2002). Foreword. Journal of Brand Management, 9(4-5), 229-239.

Anholt, S. (2006). Why brand? Some practical consideration for nation branding . Place Branding, 2(3), 179-182.

Anholt, S. (2007). Competitive idenity: The new brand management for nations, cities and regions. London: Palgrave Macmillan.

Anholt, S. (2010). Places: Identity, image and reputation. United Kingdom: Palgrave.

Braun, E., \& Zenker, S. (2010). Towards an integrated approach for place brand management. Paper presented at the $50^{\text {th }}$ European Regional Science Association Congress, Sweden, 19-23 August.

Brooks, R. (2004, 14-16 March). Rules for successful tourism marketing. Wisconsin governor's conference on tourism (pp. 1-2). Madison: Center for Comunity Economic Develoment, University of Wisconsin.

Brown, T. J., Dacin, P. A., Pratt, M. G., \& Whetten, D. A. (2006). Identity, intended image, constructed image, and reputation: An interdiciplinenary framework and suggested terminology. Journal of Academy of Marketing Science, 34(2), 99-106.

Dinnie, K. (2008). Nation branding: Concept, issues, practice. Burlington: Butterworth-Heineman.

Dinnie, K., Melewar, T. C., Seidenfuss, K. U., \& Musa, G. (2010). Nation branding and integrated marketing communication: An ASEAN pespective. International Marketing Review, 388-403.

Elliot, S., \& Papadopoulos, N. (2006). Toward a conprehensive place brand: Expanding the measurement of tourism destination image. Annual Conference of the Travel and Tourism Research Association (pp. 1-11). Canada: Cardiff School of Management.

Elliot, S., Papadopoulos, N., \& Kim, S. S. (2010). An integrative model of place image: Exploring realtionship between destination, product, and country image. Journal of Travel Research, 1-15.

Fan, Y. (2008, 14-16 December). Key pespective in nation image: A conceptual framework fo nation branding. The 6th Conference id Asia Academy of Management. Taipei.

Fan, Y. (2006). Branding the nation: What is being branded. Journal of Vacation Marketing, 5-14. 
Fan, Y. (2008). Soft power: Power of attraction or confusion? Journal of Place Branding and Public Diplomacy, 147-158.

Fan, Y. (2010). Branding the nation: Towards a better understanding. Place Branding and Public Diplomacy, 97-103.

Gertner, D., \& Kotler, P. (2004). How can a place correct a negative image. Place Branding, 1(1), 50-57.

Gilmore, F. (2002). What should be a successful national brand be based on? Journal of Brand Management, 281-293.

Gioia, D. A., Schultz, M., \& Corley, K. G. (2000). Orgnizational identity, image and adaptive instability. Academy of Management Review, 25(1), 63-81.

Gnoth, J. (2002). Leveraging export brands through a tourism destination brand. Journal of Brand Management, 9(4/5), 262-280.

Heslop, L. A., \& Papadopoulos, N. (1993). Product country images: Impact and role in international marketing. Routledge: International Business Press.

Hsieh, M. H., Pan, S. L., \& Setiono, R. (2004 ). Product, corporate, and country-image dimensions and purchase bahaviour. Journal of the Academy of marketing Science, 32(3), 251-270.

Hsieh, M. H., Pan, S. L., \& Setiono, R. (2004). product, corporate, and country-image dimensions and purchase bahaviour. Journal of the Academy of Marketing Science, 32(3), 251-270.

Johansson, J. K. (2005). The new 'brand America'. Place Branding, 1(2), 155-163.

Kaneva, N. (2011). Nation branding-toward an agenda for critical research. International Journal of Communication, 117-141.

Keilor, B. D., \& Hult, G. M. (1999). A five-country study of national identity: Implication for international marketing research and practice. International Marketing, 65-82.

Keller, K. L. (2003). Strategic brand management: Building, measuring, and managing brand equity. New Jersey: Prentice-Hall.

Kotler, P., \& Gertner, D. (2002). Country as brand, product, and beyond: A place marketing and brand management perspective. Journal of Brand Manegement, 249-262.

Leiper, N. (1990). Tourism system: An interdisiplinary perspective. Palmerson North, New Zealand: Massey University.

Morgan, N., Pritchard, A., \& Piggott, R. (2002). New Zealand, 100\% pure: The creation of a powerful niche destination brand. Journal of Brand Management, 9(4/5), 335-354.

O' Shaughnessy, J., \& O' Shaughnessy, N. J. (2002). Treating the nation as a brand: Some neglected issue. Journal Macromarketing, 56-64. 
Olins, W. (2002). Branding the nation-The historical context. Journal of Brand Management, 241-248.

Pappu, R., Quester, P. G., \& Cooksey, R. W. (2007). Country image and consumer-based brand equity: Relationship and implications for international marketing. Journal of International Business Studies, 726-745.

Prichard, A., \& Morgan, N. J. (2001). Culture, idenitty and tourism representation: Marketing Cymru or Wales? Tourism Management, 167-179.

Szondi, G. (2007). The role and challenges of country branding in transition countries: The Central and Eastren European experiences. Place Branding and Public Diplomacy, 3(1), 8-20.

Szondi, G. (2008). Public diplomacy and nation branding: Conceptal similarities and differences. Nederlands Institute of International Relations 'Clingendael'.

Whetten, D. A., \& Mackey, A. (2002). A social actor conception of organizational identity and its implications for the study of organizational reputation. Business and Society, 41(4), 393-414.

Wood, R. T. (2006). Straightedge: Complexity and contradictions of a subculture. New York: Syracuse University Press.

Zenker, E. V. (2011). Anarchism: A criticism and history of the anarchist theory. Portland: Gregorivs. 



\title{
HUBUNGAN ANTARA KUALITI PRODUK, KUALITI PERKHIDMATAN DAN KEPUASAN PELANGGAN DALAM PERBANKAN ISLAM
}

\author{
RELATIONSHIP BETWEEN PRODUCT QUALITY, \\ SERVICE QUALITY AND CUSTOMER SATISFACTION \\ IN ISLAMIC BANKING
}

\author{
MOHD FAUZWADI MAT ALI \\ ABU BAKAR HAMED \\ MUHAMMAD NASRI MD HUSSAIN \\ Islamic Business School \\ Universiti Utara Malaysia
}

\begin{abstract}
Abstrak
Perkembangan sistem perbankan Islam di Malaysia adalah berdasarkan kepada kesedaran dan permintaan masyarakat kepada suatu sistem yang bebas daripada unsur gharar dan riba. Justeru, objektif utama kajian ini adalah untuk mengkaji hubungan antara kualiti produk dan kualiti perkhidmatan dengan kepuasan pelanggan dalam perbankan Islam. Kualiti produk melibatkan keselesaan dan keberadaan produk, manakala kualiti perkhidmatan adalah kepatuhan, jaminan, ketara, empati, responsif dan kebolehpercayaan. Kajian ini melibatkan data kuantitatif dan data dikutip dengan menggunakan soal selidik. Pembantu penyelidik digunakan bagi mengutip data dari responden yang merupakan pelanggan perbankan Islam. Sebanyak 266 borang soal selidik telah diterima untuk dianalisis dengan menggunakan program Statistical Package for Social Science (SPSS). Analisis deskriptif kepuasan pelanggan perbankan Islam adalah tinggi. Begitu juga bagi faktor-faktor kualiti produk dan kualiti perkhidmatan. Kesemua faktor kualiti produk dan kualiti perkhidmatan menunjukkan korelasi yang positif dan signifikan dengan kepuasan pelanggan. Analisis regrasi berbilang menunjukkan pemboleh ubah kualiti produk dan kualiti perkhidmatan menerangkan 64 peratus varian dalam kepuasan pelanggan. Faktor responsif, empati, ketara, kepatuhan dan keberadaan produk merupakan faktor-faktor yang mempengaruhi kepuasan pelanggan secara signifikan. Keputusan menunjukkan bahawa pelanggan berpuas hati terhadap kualiti produk dan kualiti perkhidmatan yang disediakan oleh pihak perbankan Islam. Pihak perbankan Islam seharusnya memberikan perhatian yang khusus dan prihatin kepada kehendak pelanggan, meyakinkan
\end{abstract}


pelanggan dengan kepatuhan syariah terhadap produk yang ditawarkan, menonjolkan kemudahan dari segi fizikal, peralatan dan penampilan imej kakitangan serta berkeinginan untuk membantu dan menaikkan imej institusi perbankan Islam.

Kata kunci: Kepuasan pelanggan; kualiti produk; kualiti perkhidmatan; perbankan Islam; Islam; Malaysia.

\begin{abstract}
Purpose - The Islamic banking orientation of product and service qualities and its impact on the satisfaction of the customers have received considerable attention from Islamic marketing literature. The aim of this paper is to focus on the empirical research issue on the Islamic banking sector in Malaysia. Thus, the study attempts to examine the relationship between product and service qualities on customer satisfaction from the customers' perspective.

Design/Methodology/Approach - The data were collected from a sample of 266 customers of Islamic banks which operated in the northern region of Malaysia. The paper uses regression analysis to examine the impact of product and customer qualities on customer satisfaction.
\end{abstract}

Findings - It was found that product and service qualities are important to customer satisfaction in the Islamic banking sectors. Descriptive statistical results demonstrate that the customers are concerned with products which were syariah compliant. They are also perceived important on tangible and product availability factors as well. The result of the multiple regression model indicates that 64 per cent of the variation in customer satisfaction is explained by the dimensions of product and service qualities. It is found that only five factors i.e. responsive, empathy, compliance, availability of product and tangible assets are significant to the model.

Research Limitations/Implications - The paper shows that the study is limited in the area of study and the Islamic banks involved. The results may not be generalised to the other regions of Malaysia. Further research may sample customers of Islamic banks throughout Malaysia.

Practical Implications - The findings in the paper suggest that the management of Islamic banks could carefully offer products which are syariah compliant as well as upgrade their quality of services.

Originality/Value - The paper presents an empirical assessment of customers' perceptions of the product and service qualities of Islamic banks. 
It is aimed at providing some knowledge of Islamic concepts and practices in order to help Islamic banking employers and employees to upgrade their institution as well as the image of Islam.

Keywords: Customer satisfaction, product quality, service quality, Islamic banking, Islam, Malaysia.

Paper Type - Research paper.

\section{Pengenalan}

Malaysia bukan hanya menjalankan sistem perbankan Islam sahaja, malah ia merangkumi sistem kewangan Islam secara keseluruhan (Norafifah Ahmad \& Sudin Haron, 2002). Ia juga dijalankan secara bersama dengan sistem konvensional (Ab. Mumin, 2002). Sistem yang digunakan dalam sistem kewangan Islam di Malaysia, secara amnya mengamalkan sistem yang sama dengan sistem kewangan yang lain di mana konsep mengumpul deposit dari pelanggan dan melaburkannya ke dalam perniagaan yang akan memberikan keuntungan kepada pihak syarikat dan pelabur (Othman \& Owen, 2001).

Kepuasan pelanggan merupakan salah faktor penting dalam menjamin kejayaan sesuatu organisasi perniagaan. Sistem perbankan Islam di Malaysia terus berkembang pesat walaupun mendapat persaingan yang kuat daripada sistem perbankan konvensional. Pihak bank perlu sentiasa menjaga tahap kepuasan pelanggan dengan memastikan produk dan perkhidmatan yang ditawarkan adalah berkualiti dan menjadi pilihan pelanggan serta dapat menarik seberapa banyak yang mungkin pelanggan-pelanggan baru.

Permasalahan yang melibatkan kualiti produk dan kualiti perkhidmatan dalam institusi perbankan merupakan isu yang sering mendapat perhatian oleh semua pihak kerana ia melibatkan kepuasan pelanggan. Oleh itu, kualiti produk, kualiti perkhidmatan dan kepuasan pelanggan akan menentukan kestabilan sesebuah syarikat dalam institusi perbankan. Menurut Othman dan Owen (2000), operasi perniagaan dan pelaburan yang diamalkan dalam sistem perbankan Islam adalah berdasarkan kepada prinsip-prinsip Islam, ini adalah berbeza dengan konsep pelaburan yang diamalkan dalam sistem perbankan konvensional. Terdapat beberapa perbezaan, iaitu 
penghapusan kadar faedah (riba), prosedur dan perjanjian kewangan yang berdasarkan kepada prinsip perniagaan Islam. Dalam hal ini, sistem perbankan Islam menawarkan sistem pembahagian keuntungan (profit sharing) dalam setiap pelaburan yang ditawarkan.

Parasuraman, Zeithaml dan Berry (1985) mengatakan bahawa banyak kajian telah membuktikan kualiti perkhidmatan merupakan strategi yang penting untuk mencapai kejayaan dan kecemerlangan bagi setiap organisasi. Manakala Othman dan Owen (2000) pula mendapati bahawa kualiti perkhidmatan yang baik merupakan asas bagi kejayaan setiap organisasi yang terlibat dalam sektor perkhidmatan termasuk institusi kewangan Islam. Sehubungan itu, institusi perbankan Islam bukan saja menghadapi persaingan yang kuat daripada institusi perbankan konvensional, malah menghadapi persaingan dalam kalangan institusi-institusi perbankan Islam sendiri (Nasir, Jamal, \& Al-Khatib, 1999).

Menurut Ketua Pegawai Eksekutif Southern Finance Berhad, Abdul Rahim Mohd Zin (2002), institusi perbankan Islam juga berhadapan dengan masalah teknikal seperti proses operasi yang kompleks dan kekurangan latihan dalam kalangan kakitangan terutamanya bagi yang datang dari perbankan konvensional. Hal ini menimbulkan permasalahan dalam memahami dan melaksanakan peraturanperaturan yang ditetapkan oleh syariah. Mantan Perdana Menteri Malaysia, Tun Abdullah Ahmad Badawi juga menyarankan ahli akademik memberi tumpuan penyelidikan dan pembangunan dalam sektor perbankan kerana mutu perkhidmatannya masih jauh daripada memuaskan.

Persoalan yang timbul di sini bolehkah sistem perbankan Islam bersaing dalam arus kontemporari dan dapat meyakinkan industri perbankan. Hal ini kerana ramai masyarakat belum mengerti dan memahami sistem perbankan Islam (Sheikh Muttaqun, 2001). Sementara itu, Dewan Perniagaan Melayu Malaysia pernah melaporkan isu pembocoran rahsia pelanggan juga berlaku dalam sistem perbankan Islam (DPMM, 2000). Di awal usia penubuhan, perbankan Islam di Malaysia juga menghadapi masalah kakitangan kaunter yang kurang peramah, kesibukan keterlaluan, talian telefon yang sukar dihubungi dan jam bekerja yang terbatas (Rahim Abdullah, 1996). Isu-isu di atas memberi ruang kepada penyelidik melakukan penyelidikan persepsi pelanggan terhadap produk dan perkhidmatan yang disediakan oleh pihak perbankan Islam dan sejauh manakah pelanggan berpuas hati dengan produk dan perkhidmatan tersebut. 
IJMS 20 (1), 185-202 (2013)

\section{Persoalan Kajian}

\section{Sistem Perbankan Islam}

Sistem Perbankan Islam di Malaysia mula dilaksanakan dengan tertubuhnya Bank Islam Malaysia Berhad pada tahun 1983. Ia diperbadankan di bawah Akta Syarikat 1965. Kejayaan Lembaga Urusan dan Tabung Haji Malaysia dan bank-bank Islam di negara luar seperti Pakistan dan Kuwait telah mendorong penubuhannya bankbank Islam di Malaysia. Bank Islam Malaysia Berhad ditubuhkan dengan modal berbayar RM80 juta daripada modal dibenarkan iaitu RM 500 juta dengan 32 peratus dimiliki oleh kerajaan Persekutuan dan bakinya oleh kerajaan-kerajaan negeri dan institusi agama Islam. Bank Islam Malaysia Berhad dilesenkan di bawah Akta Bank Islam 1983 dan diawasi oleh Bank Negara Malaysia di bawah Akta itu. Bank Islam kedua pula iaitu Bank Muamalat telah ditubuhkan pada 1 Oktober 1999 bersamaan 21 Jamadil Akhir 1420 Hijriah. Penubuhan Bank Muamalat Malaysia Berhad adalah berikutan pergabungan antara Bank Bumiputera Malaysia Berhad dan Bank Commerce (M) Berhad. Aset Bank Mualamat pada ketika itu terdiri daripada aset perbankan Islam BBMB, BOC dan BBMB Kewangan Berhad (BBMBK) yang disatukan. Modal berbayar Bank Muamalat semasa ia ditubuhkan berjumlah RM300 juta. Sementara itu, produk dan perkhidmatan yang disediakan ialah Akaun Simpanan al-Wadiah, Akaun Semasa alWadiah, Akaun Pelaburan Am al-Mudharabah, al-Bai Bithaman Ajil (BBA), Pembiayaan Modal Kerja Muamalah, Surat Kredit al-Wakalah, Jaminan Perkapalan al-Kafalah, Surat Jaminan al-Kafalah dan Bil Penerimaan Islam.

Pada dasarnya produk perbankan Islam adalah produk perbankan yang mematuhi prinsip-prinsip syariah iaitu ia hendaklah berintipatikan ajaran Islam sepenuhnya, bukan hanya pada labelnya sahaja (Nor Mohamed Yakcop, 1996). Produk perbankan Islam seharusnya mematuhi semua peraturan dalam sistem muamalah Islam. Islam menegah amalan yang mengandungi unsur riba, gharar, perjudian, tipu muslihat dan sebagainya. Dengan kata lain, produk perbankan Islam mestilah mencerminkan nilai, akhlak dan etika Islam.

Untuk bersaing di pasaran, produk perbankan Islam hendaklah mempunyai ciri-ciri yang canggih dan berdaya maju. Keperluan untuk mematuhi prinsip-prinsip syariah tidak bermakna aspek dan nilai-nilai komersial produk perbankan Islam harus diabaikan 
(Ab. Mumin \& Noor Azzah, 2002). Hal yang demikian adalah bertepatan kerana institusi perbankan Islam itu sendiri bukanlah organisasi kebajikan, sebaliknya ia merupakan organisasi berasaskan keuntungan. Namun konsep keuntungan bagi institusi perbankan Islam adalah berbeza daripada institusi perbankan konvensional. Dalam usaha mengejar keuntungan, keputusan-keputusan kewangan dalam institusi perbankan Islam mestilah berlandaskan panduan ajaran Islam dan mengambil kira kepentingan masyarakat, negara dan agama. Sebaliknya, perbankan konvensional bertujuan untuk memaksimakan keuntungan semata-mata. Justeru, produk perbankan Islam yang dibangunkan mestilah viable agar dapat bersaing dengan produk konvensional dari semua aspek (Nor Mohamed Yakcop, 1996) serta memastikan keuntungan daripada operasi dan pelaburan yang dibuat, di samping mencapai objektif sosioekonomi masyarakat Islam (al-Sadr, 1983; Uzair, 1980; Joni, 2002).

Produk-produk yang telah terbukti berdaya maju yang ditawarkan oleh institusi perbankan Islam meliputi akaun simpanan, akaun semasa, akaun pelaburan, pembiayaan projek, pembiayaan modal kerja, pembiayaan peribadi, kemudahan overdraf tanpa faedah, pembiayaan perumahan, pembiayaan kenderaan, pembiayaan aset tetap, bil penerimaan secara Islam, kemudahan pembiayaan semula kredit eksport secara Islam, surat jaminan bank, kemudahan surat kredit dan kad kredit. Pembangunan produk-produk perbankan Islam tersebut di asakan dari konsep-konsep al-Wadiah yad Dhamanah, al-Mudarabah, al-Musyarakah, al-Murabahah, Bay' Bithaman Ajil, Bai'al-Dayn, al-Ijarah, al-Ijarah Thumma al-Bay', Bai' as-Salam, Bai' al-Istijrar, al-Qardhul Hasan, al-Kafalah, al-Wakalah, al-Hiwalah, alSarf, ar-Rahn, al-Ujr, dan al-Hibah.

\section{Kualiti Produk dan Kualiti Perkhidmatan}

Biasanya kualiti produk dikaitkan dengan sifat produk. Dalam konteks produk perbankan, Wang, Lo dan Hui (2003) mengaitkan produk dengan kesesuaian penggunaan dan jaminan. Mereka menyarankan agar kualiti produk dikategorikan kepada dua dimensi iaitu keberadaan produk dan keselesaan produk. Keberadaan produk merujuk kepada ciri-ciri dan kepelbagaian produk yang ditawarkan oleh pihak bank kepada pelanggan. Keselesaan produk pula merujuk kepada produk yang senang dan mudah untuk digunakan yang ditawarkan oleh pihak bank kepada pelanggan. Garvin (1988) pula 
membahagikan kualiti produk kepada lapan dimensi iaitu dimensi prestasi, sifat, reka bentuk, ciri-ciri produk mengikut standard yang ditetapkan, jaminan, ketahanan, tahap kemampuan perkhidmatan, estetik dan reputasi syarikat.

Sementara itu, kualiti merujuk kepada pertimbangan, sikap dan tingkah laku yang berkaitan dengan perkhidmatan yang baik (Avkiran, 1999). Menurut Parasuraman, Berry dan Zeithaml (1988), kualiti perkhidmatan adalah jurang antara perkhidmatan yang diharapkan oleh pelanggan dengan apa yang mereka dapati dari syarikat. Ia melibatkan pertimbangan, sikap dan tingkah laku yang berkaitan dengan perkhidmatan yang baik (Avkiran, 1999). Parasuraman, Berry dan Zeithaml (1991) telah membina instrumen SERQUAL terdiri daripada lima dimensi iaitu dimensi ketara, kebolehpercayaan, responsif, jaminan dan empati. Manakala Othman dan Owen (2001) telah menambah dimensi kepatuhan bagi mengkaji kualiti perkhidmatan dalam sistem perbankan Islam. Definisi konsep dimensi-dimensi berkenaan adalah seperti berikut:

(a) Kepatuhan yang merujuk kepada kemampuan pihak bank untuk memenuhi dan mengikuti perundangan Islam serta beroperasi mengikut prinsip ekonomi dan perbankan Islam.

(b) Jaminan merujuk kepada pengetahuan, kejujuran pekerja dan kemampuan mereka untuk mewujudkan kepercayaan dan keyakinan kepada pelanggan.

(c) Kebolehpercayaan merupakan kemampuan pihak tertentu untuk menunaikan tanggungjawab, boleh dipercayai dan tepat sebagaimana yang telah dijanjikan.

(d) Ketara melibatkan kemudahan dari segi fizikal, peralatan dan penampilan kakitangan.

(e) Empati merujuk kepada memberi perhatian dan mengambil berat secara khusus kepada setiap individu.

(f) Responsif melibatkan kemahuan atau keinginan untuk menolong dan menyediakan perkhidmatan yang cepat kepada pelanggan.

Kajian awal menunjukkan kualiti produk dan perkhidmatan menjadi rujukan pelanggan dalam menilai operasi sistem perbankan Islam. Kajian oleh Metawa dan Almossawi (1998) mendapati bahawa pelanggan berpuas hati terhadap produk dan perkhidmatan yang disediakan oleh pihak bank-bank Islam di Bahrain terutamanya produk akaun pelaburan, akaun simpanan, akaun semasa dan mesin 
juruwang automatik. Pelanggan juga sangat berpuas hati terhadap layanan pekerja-pekerja bank, lokasi bank, waktu berurus niaga dan kemudahan-kemudahan yang disediakan oleh pihak bank. Sebaliknya pelanggan tidak berpuas hati dengan kemudahan kewangan, money order, bank draft dan cek kembara.

Sementara itu, Nasir, Jamal dan Al-Khatib (1999) mendapati bahawa pelanggan bank Islam di Jordan pula sangat berpuas hati dengan produk dan perkhidmatan yang disediakan oleh bank-bank yang terlibat dalam sistem perbankan Islam. Walaupun begitu, penyelesaian masalah melalui telefon yang ditawarkan oleh pihak bank tidak mendapat sambutan pelanggan. Kajian tersebut menyarankan agar pihak bank memberi latihan berinteraksi melalui telefon kepada kakitangan agar mereka lebih ramah dan profesional. Manakala, Othman dan Owen (2000) pula mendapati pelanggan yang berurusan dengan Kuwait Finance House berpuas hati terhadap produk dan perkhidmatan yang disediakan oleh pihak bank, hubungan antara pekerja dan pelanggan, dan juga kualiti perkhidmatan yang disediakan. Metawa dan Almossawi (1998) melaporkan bahawa majoriti pelanggan berpuas hati dengan produk dan perkhidmatan yang ditawarkan oleh perbankan Islam. Mereka mendapati 63.8 peratus pelanggan yang melabur dalam akaun pelaburan dan 86.7 peratus pelanggan yang melabur dalam akaun simpanan berpuas hati dengan kualiti produk-produk tersebut.

Angur, Nataraajan dan Jahera (1999) mendapati bank-bank Islam di India mengutamakan kualiti perkhimatan dengan faktor ketara mendahului, diikuti oleh kebolehpercayaan, responsif, jaminan dan empati. Sementara itu, Lee, Lee dan Yoo (2000) juga mendapati dimensi ketara adalah faktor yang paling dominan dalam dimensi kualiti perkhidmatan diikuti oleh faktor responsif. Wong dan Sohail (2002) mengkaji hubungan antara dimensi kualiti perkhidmatan dengan keseluruhan kualiti (pekerja dan syarikat). Mereka mendapati bahawa dimensi ketara menjadi rujukan utama pelanggan, diikuti oleh kebolehpercayaan, responsif, jaminan dan empati.

Sureshchandar, Rajendran dan Anantharaman (2003) pula mengkaji persepsi pelanggan terhadap kualiti perkhidmatan bank-bank di India. Mereka mendapati pelanggan lebih mengutamakan elemen manusia, diikuti oleh teras perkhidmatan, sistematik, ketara dan tanggungjawab sosial. Manakala di Cina pula Wang et al. (2003) menunjukkan dimensi ketara, responsif dan jaminan mempunyai hubungan yang signifikan dengan keseluruhan kualiti perkhidmatan. 
Sementara itu kajian oleh Ndubisi (2003) tentang persepsi pelanggan terhadap kualiti perkhidmatan bank di Sabah dan Sarawak mendapati pelanggan lebih utamakan faktor ketara, diikuti oleh faktor kebolehpercayaan, responsif, jaminan dan empati. Perbincangan di atas menjelaskan kualiti perkhidmatan adalah merupakan di antara penentu kepuasan pelanggan dalam sektor perbankan (Levesque \& McDougall, 1996).

\section{Kepuasan Pelanggan}

Kepuasan pelanggan merupakan perasaan atau sikap pelanggan terhadap produk atau perkhidmatan selepas menggunakan produk atau perkhidmatan tersebut (Solomon, 1996). Ia berkait dengan nilai perbandingan di antara perkhidmatan yang diterima dan jangkaan terhadap perkhidmatan yang diharapkan. Jika prestasi yang diberikan tidak memenuhi jangkaan, pelanggan tidak akan berpuas hati. Sebaliknya, jika prestasi yang diberikan adalah sama seperti yang dijangkakan, pelanggan akan berpuas hati. Apabila prestasi yang diberikan adalah melebihi jangkaan, pelanggan adalah sangat berpuas hati (Kotler et al., 1999).

Kepuasan pelanggan akan menyebabkan berlaku pembelian yang berulangan terhadap produk oleh pelanggan dan mereka akan membawa imej yang baik yang positif tentang produk tersebut kepada pihak lain. Sebaliknya, jika pelanggan tidak berpuas hati terhadap produk atau perkhidmatan maka mereka akan menukar pembelian dengan membeli produk lain dan berkemungkinan menyampaikan persepsi yang negatif (Gulledge, 1996) kepada produk tersebut. Dalam memenuhi jangkaan pelanggan, organisasi perlu mengetahui bagaimana seseorang pelanggan itu melihat sesuatu barangan atau perkhidmatan bagi memenuhi kehendak dan keperluannya.

Penemuan awal mendapati bahawa terdapat hubungan positif yang signifikan di antara kualiti perkhidmatan dan kepuasan pelanggan sebagaimana. Nguyen dan LeBlanc (1998) melaporkan bahawa kualiti perkhidmatan dan kepuasan pelanggan berhubungan secara positif dengan nilai pelanggan. Kualiti berupaya memberi kesan yang lebih besar terhadap nilai pelanggan berbanding dengan kepuasan pelanggan. Penemuan di atas juga telah disokong oleh Caruana (2002) yang mendapati bahawa kualiti perkhidmatan merupakan penyumbang terbesar kepada kepuasan pelanggan, diikuti faktor pengurusan dan reputasi serta imej sesebuah bank. 
Wong dan Sohail (2002) mendapati dimensi ketara menjadi rujukan utama pelanggan, diikuti oleh kebolehpercayaan, responsif, jaminan dan empati, tetapi mereka hanya mendapati dimensi empati sebagai penyumbang yang signifikan terhadap keseluruhan kualiti untuk pekerja dan syarikat. Manakala Othman dan Owen (2000) dan Angur, Nataraajan dan Jahera (1999) mendapati kualiti perkhidmatan mempengaruhi kepuasan. Sementara itu, Nguyen dan LeBlanc (1998) melaporkan kualiti perkhidmatan dan kepuasan pelanggan mempunyai hubungan yang positif dengan nilai pelanggan. Lassar, Manolis dan Winsor (2000) juga mendapati kualiti perkhidmatan mempunyai hubungan dengan kepuasan pelanggan dan mereka mendapati faktor empati paling kritikal kepada kepuasan pelanggan.

Hubungan kualiti perkhidmatan dan kepuasan pelanggan dalam sektor perbankan mempunyai hubungan positif yang kuat (Levesque \& McDougall, 1996). Kajian oleh Angur et al. (1999) yang menggunakan model SERVQUAL (Parasuraman et al., 1991) mendapati bahawa terdapat hubungan yang signifikan di antara kualiti perkhidmatan dan kepuasan pelanggan. Selain itu Lassar et al. (2000) juga mendapati bahawa SERVQUAL dan Technical/Functional Quality mempengaruhi kepuasan pelanggan dengan dimensi empati merupakan faktor yang paling dominan. Manakala Caruana, Money dan Berthon (2000) mendapati kualiti perkhidmatan mempunyai hubungan yang signifikan dengan kepuasan pelanggan. Kajian menunjukkan kualiti perkhidmatan menerangkan varian kepuasan pelanggan sebanyak 50 peratus. Sementara itu kajian Caruana (2002) pula melaporkan bahawa sebanyak 20 peratus variasi dalam kepuasan pelanggan diterangkan oleh kualiti perkhidmatan.

Perbincangan di atas menunjukkan keperluan sektor perbankan Islam meningkatkan keunikan dan kualiti produk serta perkhidmatan bagi meneruskan persaingan dalam pasaran. Perbankan Islam dijangka akan menghadapi persaingan yang hebat dari institusi kewangan konvensional yang sudah bertapak lama dan mempunyai syer pasaran yang besar. Oleh itu, institusi perbankan Islam perlu mengambil tanggungjawab yang serius dengan membina persepsi dan imej dalam industri perbankan dalam kalangan pelanggan dan masyarakat. Peningkatan kualiti produk dan perkhidmatan secara berterusan dan berdaya saing amat diperlukan oleh pihak pengurusan perbankan Islam menjamin survival dan seterusnya meletakkan martabat sistem perbankan Islam di tahap yang tinggi. 
Justeru, hipotesis kajian ini adalah untuk mengkaji fakor produk dan faktor kualiti perkhidmatan yang disediakan oleh institusi perbankan Islam dalam menerangkan kepuasan pelanggan.

\section{Metodologi}

Kajian ini adalah merupakan kajian kuantitatif bertujuan untuk mengkaji hubungan kualiti produk dan kualiti perkhidmatan dengan kepuasan pelanggan. Kualiti produk melibatkan dua dimensi iaitu keberadaan produk dan keselesaan produk (Wang et al., 2003); manakala dimensi kualiti perkhidmatan melibatkan dimensi kepatuhan (Othman \& Owen, 2001), jaminan, kebolehpercayaan, ketara, empati dan responsif (Othman \& Owen, 2002; Parasuraman et al., 1991); dan kepuasan pelanggan pula menggunakan instrumen yang telah dibentuk oleh McDougall dan Levesque (1994) dan Othman dan Owen (2001). Kesemua dimensi ini adalah pemboleh ubah dalam kajian ini yang akan diuji hubungan dengan pemboleh ubah kepuasan pelanggan.

Kajian ini merupakan kajian lapangan. Soal selidik telah dibentuk berdasarkan kajian-kajian lepas. Ia terdiri daripada empat bahagian iaitu bahagian A berkaitan latar belakang responden, bahagian B merangkumi kualiti produk (Wang et al., 2003) yang mengandungi 10 item soalan, bahagian $\mathrm{C}$ melibatkan kualiti perkhidmatan yang terdiri daripada 29 item soalan (Othman \& Owen, 2002; Parasuraman et al., 1991), dan bahagian D mengukur kepuasan pelanggan (McDougall \& Levesque, 1994; Othman \& Owen, 2001). Skala likert lima mata bermula dari sangat tidak setuju (1) hingga sangat setuju (5) yang digunakan bagi mengukur item-item soalan dalam soal selidik untuk bahagian B, C dan D.

Data bagi kajian ini dikutip dengan menggunakan soal selidik berstruktur dan diisi sendiri oleh responden. Kajian melibatkan pelanggan-pelanggan institusi perbankan Islam di Kedah, Perlis dan Pulau Pinang. Pelanggan yang dipilih menjadi responden akan diberi soal selidik oleh pembantu penyelidik semasa mereka berurusan dengan pihak bank. Responden diminta mengisi soal selidik dan memulangkan semula kepada pembanci. Pembanci akan menyemak soal selidik yang dipulangkan oleh responden agar maklumat yang diisi lengkap. Sejumlah 266 soal selidik telah diedarkan kepada responden dan digunakan untuk dianalisis. Data dianalisis dengan menggunakan program SPSS. Latar belakang responden akan 
dianalisis dengan menggunakan frekuensi dan peratusan. Sementara itu korelasi antara pemboleh ubah dilakukan dengan menggunakan analisis korelasi pearson. Manakala, pengaruh kualiti produk dan kualiti perkhidmatan terhadap kepuasan pelanggan akan menggunakan analisis regrasi berbilang.

Keputusan analisis reliabiliti bagi kajian ini mendapati nilai Cronbach alpha bagi pemboleh ubah yang terlibat dalam kajian adalah antara 0.75 dan 0.84 iaitu pada tahap yang tinggi kebolehpercayaannya. Pembolehubah kualiti produkiaitu keberadaan produkdankeselesaan produk memberi nilai Cronbach alpha masing-masing dengan nilai 0.83 dan 0.82 . Manakala bagi dimensi kualiti perkhidmatan pula yang melibatkan pemboleh ubah kepatuhan $(\alpha=0.87)$, jaminan $(\alpha=0.75)$, kebolehpercayaan $(\alpha=0.81)$, ketara $(\alpha=0.77)$, empati $(\alpha=0.71)$ dan responsif $(\alpha=0.77)$ mempunyai nilai Cronbach alpha yang tinggi. Seterusnya nilai alpha bagi pemboleh ubah kepuasan pelanggan adalah juga di tahap yang tinggi $(\alpha=0.84)$.

\section{Keputusan Kajian}

\section{Latar belakang responden}

Jadual I menunjukkan ciri-ciri demografi responden yang terlibat dalam kajian ini. Jadual menerangkan pelanggan lelaki (53.3 peratus) sedikit melebihi pelanggan perempuan (44.7 peratus) yang berurusan dengan institusi perbankan Islam di utara Malaysia. Bangsa melayu adalah majoriti pelanggan (77.4 peratus), manakala pelanggan beragama Islam (80.1 peratus) paling ramai menggunakan perkhidmatan perbankan Islam. Kebanyakan pelanggan berumur antara 21 hingga 25 tahun (31.6 peratus) dan sudah berkahwin (55.3 peratus).

Jadual 1

Latar Belakang Responden

\begin{tabular}{lcclccc}
\hline & Bil & $\%$ & & Bil & $\%$ \\
\hline Jantina & & & Umur & & \\
$\quad$ Lelaki & 147 & 55.3 & 20 tahun ke bawah & 28 & 12.1 \\
$\quad$ Perempuan & 119 & 44.7 & $21-25$ & 73 & 31.6 \\
Bangsa & & & $26-30$ & 57 & 24.7 \\
$\quad$ Melayu & 206 & 77.4 & $31-35$ & 35 & 15.2 \\
$\quad$ Bukan Melayu & 60 & 22.6 & $36-40$ & & 16 & 6.9 \\
\hline & & & & &
\end{tabular}


IJMS 20 (1), 185-202 (2013)

\begin{tabular}{lrrrcc}
\hline & Bil & $\%$ & & Bil & $\%$ \\
\hline Agama & & & 41 ke atas & 22 & 9.5 \\
$\quad$ Islam & 213 & 80.1 & & & \\
$\quad$ Bukan Islam & 53 & 19.9 & & & \\
Status Perkahwinan & & & & & \\
$\quad$ Bujang & 147 & 55.3 & & & \\
$\quad$ Berkahwin & 119 & 44.7 & & \\
\hline
\end{tabular}

\section{Perkaitan dimensi-dimensi produk dan perkhidmatan dan kepuasan pelanggan}

Jadual 2 menunjukkan hasil keputusan analisis pearson. Keputusan deskriptif dari analisis pearson menunjukkan bahawa persepsi pelanggan terhadap kualiti produk dan perkhidmatan perbankan Islam berada pada tahap yang agak tinggi; didahului oleh pemboleh ubah kepatuhan $(\min =4.07)$, diikuti oleh ketara $(\min =3.92)$, keberadaan produk $(\min =3.88)$, keselesaan produk $(\min =3.79)$, jaminan $(\min =3.76)$, empati $(\mathrm{min}=3.76)$, kebolehpercayaan $(\mathrm{min}=$ 3.68) dan responsif $(\mathrm{min}=3.68)$. Manakala pemboleh ubah kepuasan pelanggan $(\min =3.88)$ juga mempunyai min skor yang tinggi.

Keputusan analisis statistik pearson pula mendapati bahawa kesemua pemboleh ubah mempunyai korelasi secara positif dan signifikan dengan kepuasan pelanggan. Dimensi kualiti produk iaitu pemboleh ubah keberadaan produk (0.58) dan keselesaan produk (0.51) mempunyai kekuatan hubungan yang sederhana dengan pemboleh ubah kepuasan pelanggan. Sementara itu dimensi kualiti perkhidmatan iaitu kepatuhan (0.43), jaminan (0.50), dan ketara (0.53) juga mempunyai korelasi yang sederhana; tetapi pemboleh ubah empati (0.64), responsif (0.69) dan kebolehpercayaan (0.61) mempunyai koeralsi yang agak tinggi dengan kepuasan pelanggan.

Jadual 2

Nilai Min, Sisihan Piawai dan Korelasi bagi Setiap Pemboleh Ubah

\begin{tabular}{clcc|cccccccc}
\hline No & Pemboleh ubah & M & SD & 1 & 2 & 3 & 4 & 5 & 6 & 7 & 8 \\
\hline 1 & Kepuasan Pelanggan & 3.88 & 0.49 & - & & & & & & & \\
2 & Keberadaan Produk & 3.88 & 0.55 & $0.58^{*}$ & & & & & & & \\
3 & Keselesaan Produk & 3.79 & 0.50 & $0.51^{*}$ & $0.71^{*}$ & & & & & & \\
4 & Kepatuhan & 4.07 & 0.65 & $0.43^{*}$ & $0.38^{*}$ & $0.50^{*}$ & & & & & \\
5 & Jaminan & 3.76 & 0.53 & $0.50^{*}$ & $0.39^{*}$ & $0.44^{*}$ & $0.27^{*}$ & & & & \\
6 & Kebolehpercayaan & 3.68 & 0.55 & $0.61^{*}$ & $0.58^{*}$ & $0.50^{*}$ & $0.25^{*}$ & $0.68^{*}$ & & & \\
7 & Ketara & 3.92 & 0.48 & $0.53^{*}$ & $0.44^{*}$ & $0.37^{*}$ & $0.23^{*}$ & $0.41^{*}$ & $0.50^{*}$ & & \\
8 & Empati & 3.76 & 0.45 & $0.64^{*}$ & $0.50^{*}$ & $0.49^{*}$ & $0.45^{*}$ & $0.40^{*}$ & $0.51^{*}$ & $0.48^{*}$ & \\
9 & Responsif & 3.68 & 0.53 & $0.69^{*}$ & $0.53^{*}$ & $0.44^{*}$ & $0.20^{*}$ & $0.47^{*}$ & $0.67^{*}$ & $0.46^{*}$ & $0.56^{*}$ \\
\hline
\end{tabular}

${ }^{*} P<0.01$ 


\section{Pengaruh kualiti produk dan kualiti perkhidmatan terhadap kepuasan pelanggan}

Keputusan analisis regresi berbilang (Jadual 3) menunjukkan bahawa pemboleh ubah keberadaan produk, keselesaan produk, responsif, empati, ketara, kepatuhan, jaminan, kebolehpercayaan dan responsif produk dan secara keseluruhannya adalah signifikan $(\mathrm{F}=$ 59.411, $\mathrm{p}<0.00$ ) dan telah menyumbang sebanyak 64 peratus variasi dalam pemboleh ubah kepuasan pelanggan. Walau bagaimanapun, secara individu hanya pemboleh ubah responsif, empati, ketara, kepatuhan dan keberadaan produk menunjukkan hubungan yaang signifikan dengan kepuasan pelanggan. Kesemua pemboleh ubah yang signifikan ini memberi pengaruh yang positif. Hasil kajian ini mendapati bahawa kepuasan pelanggan di pengaruhi oleh faktor responsif $(\beta: 0.363, p<0.01)$, diikuti oleh empati $(\beta: 0.192, p<0.01)$, kepatuhan $(\beta: 0.169, \mathrm{p}<0.01)$, keberadaan produk $(\beta: 0.133, \mathrm{p}<0.05)$ dan ketara $(\beta: 0.126, \mathrm{p}<0.01)$. Namun faktor keselesaan produk, jaminan dan kebolehpercayaan tidak signifikan dan seterusnya tidak mempengaruhi kepuasan pelanggan dalam perbankan Islam di Malaysia.

Jadual 3

Keputusan Analisis Regresi Berganda

\begin{tabular}{|c|c|c|c|c|c|}
\hline & \multicolumn{2}{|c|}{$\begin{array}{c}\text { Koefesian tak } \\
\text { Standard }\end{array}$} & \multirow{2}{*}{$\begin{array}{c}\text { Koefesian } \\
\text { Standard }\end{array}$} & \multirow[t]{2}{*}{$\mathrm{T}$} & \multirow[t]{2}{*}{ Sig. } \\
\hline & $\mathrm{B}$ & Std. Error & & & \\
\hline Constant & .024 & .193 & & .123 & .902 \\
\hline Keberadaan Produk & .120 & .053 & .133 & 2.258 & .02 \\
\hline Keselesaan Produk & -.028 & .057 & -.029 & -.497 & .62 \\
\hline Kepatuhan & .128 & .034 & .169 & 3.725 & .00 \\
\hline Jaminan & .079 & .049 & .084 & 1.616 & .10 \\
\hline Kebolehpercayaan & .040 & .058 & .044 & .685 & .49 \\
\hline Ketara & .130 & .047 & .126 & 2.760 & .00 \\
\hline Empati & .208 & .056 & .192 & 3.697 & .00 \\
\hline Responsif & .338 & .051 & .363 & 6.646 & .00 \\
\hline
\end{tabular}

Pemboleh ubah bebas: Kepuasan Pelanggan

$R$ square: 0.64

ANOVA: $F=59.411$, Sig. 0.00

\section{Perbincangan dan Kesimpulan}

Objektif utama kajian ini adalah untuk mengkaji pengaruh kualiti produk dan kualiti perkhidmatan terhadap kepuasan pelanggan yang terlibat dalam berurusan dengan institusi perbankan Islam. Di 
samping itu, kajian ini juga dapat mengenal pasti persepsi pelanggan terhadap kualiti produk, kualiti perkhidmatan dan kepuasan pelanggan. Keputusan kajian menunjukkan bahawa perkembangan sistem perbankan Islam di Malaysia berada di landasan yang baik kerana mendapat sambutan yang menggalakkan daripada para pelanggan sama ada yang menggunakan perbankan Islam atau perbankan konvensional. Kajian ini mendapati tahap kepuasan pelanggan perbankan Islam di Malaysia adalah agak tinggi selaras dengan penemuan kajian di Bahrin oleh Metawa dan Almossawi (1998), di Jordan oleh Naser et al. (1999) dan di Kuwait oleh Othman dan Owen (2000).

Keputusan kajian menunjukkan pelanggan bank Islam di Malaysia memberi keutamaan kepada dimensi kepatuhan, diikuti oleh ketara dan keberadaan produk. Konsep patuh syariah ini disarankan oleh Othman dan Owen (2001) iaitu bahawa produk-produk perbankan Islam perlu berupaya memenuhi tuntutan syariah. Kajian Angur et al. (1999) mendapati faktor ketara antara tiga keutamaan rujukan oleh pelanggan di samping kebolehpercayaan dan responsif. Sementara itu, Ndubisi (2003) dan Lee et al. (2000) mendapati dimensi ketara adalah faktor yang paling dominan dalam dimensi kualiti perkhidmatan diikuti oleh faktor responsif.

Keputusan regresi menunjukkan faktor responsif, empati, ketara, kepatuhan dan keberadaan produk mempunyai hubungan positif dan signifikan dengan kepuasan pelanggan. Dalam kajian ini faktor-faktor tersebut mewakili 64 peratus pengaruh terhadap kepuasan pelanggan. Nilai ini melebihi sedikit peratusan kajian Caruana et al. (2000) iaitu 50 peratus; manakala Caruana (2002) melaporkan bahawa sebanyak 20 peratus variasi dalam kepuasan pelanggan diterangkan oleh kualiti perkhidmatan. Kajian-kajian awal juga menunjukkan faktor kualiti perkhidmatan berhubung positif dan signifikan dengan kepuasan pelanggan (Parasuraman et al., 1991; Levesque \& McDougall, 1996; Nguyen \& LeBlanc, 1998; Angur et al. 1999; Caruana et al., 2000). Wong dan Sohail (2002) mendapati hanya faktor empati mempengaruhi kualiti untuk pekerja dan syarikat. Lassar et al. (2000) juga mendapati kualiti perkhidmatan mempengaruhi kepuasan pelanggan dengan dimensi empati merupakan faktor yang paling dominan.

Dalam konteks ini, pihak perbankan Islam disarankan agar mengutamakan keperluan para pelanggan sama ada dari segi kualiti produk atau kualiti perkhidmatan. Pihak bank perlu responsif bagi memenuhi kemahuan atau keinginan pelanggan untuk menolong 
dan menyediakan perkhidmatan yang cepat kepada pelanggan. Di samping itu faktor empati juga perlu diutamakan kerana dengan memberi perhatian dan mengambil berat secara khusus kepada setiap pelanggan dapat meyakinkan mereka terus menggunakan perkhidmatan perbankan Islam. Faktor ketara melibatkan kemudahan dari segi fizikal, peralatan dan penampilan kakitangan perlu juga diberi perhatian serius. Sesungguhnya perbankan Islam di Malaysia dalam awal usia mereka pembinaan imej melibatkan penawaran produk yang menarik dan patuh syariah menjadi asas kepada perkembangan industri perbankan. Kepatuhan yang merujuk kepada kemampuan pihak bank untuk memenuhi dan mengikuti perundangan Islam serta beroperasi mengikut prinsip ekonomi dan perbankan Islam. Inilah kelainan yang akan melonjak imej dan operasi perbankan Islam.

Walaupun begitu, pihak bank tidak seharusnya berpuas hati dengan penemuan ini sebaliknya perlu sedar bahawa masih terdapat ruang untuk memperbaiki dan meningkatkan lagi tahap kepuasan pelanggan. Pihak bank juga perlu peka dengan kehendak pelanggan kerana mereka merupakan faktor utama dalam menentukan kejayaan sistem perbankan Islam di Malaysia. Strategi pihak bank mempelbagaikan produk dan menjamin kualiti produk mendapat sambutan baik dari pelanggan. Pihak bank disarankan terus menyediakan produk yang pelbagai dan berdaya saing bagi menjamin kewujudan dan survival institusi perbankan Islam.

\section{Rujukan}

Ab. Mumin Ab. Ghani \& Noor Azzah Kamri. (2002, Jun 18). Harmonisasi elemen nilai dalam penawaran instrumen kewangan Islam. Kertas Kerja Seminar Kewangan Islam di Akademi Pengajian Islam Universiti Malaysia.

Ab. Mumin Ab. Ghani (2002). Sistem kewangan Islam dan pelaksanaannya di Malaysia. Kuala Lumpur: Universiti Malaya.

Abdul Rahim Mohd Zin. (2002, Jun 3). Sistem perbankan Islam menggalakkan. Utusan Malaysia, hlm. 29.

Angur, M. G., Nataraajan, R., \& Jahera, J. S. (1999). Service quality in the banking industry: An assessment in a developing economy. International Journal of Bank Marketing, 17(3), 116-123.

Bergman, B., \& Klefsjo, B. (1994). Quality: From customer needs to customer satisfaction. Lund, Sweden: McGraw Hill.

Caruana, A. (2002). Service loyalty: The effects of service quality and the mediating role of customer satisfaction. European Journal of Marketing, 36(7/8), 811-828. 
Caruana, A., Money, A. H., \& Berthon, P. R. (2000). Service quality and satisfaction: The moderating role of value. European Journal of Marketing, 34(11/12), 1338-1352.

Datuk Dr. Syed Othman Alhabshi (1995, February 14-15). Islamic Fund in Malaysia. Paper Presented at The Funds Management Industry Conference. Kuala Lumpur.

DPMM desak pembocor rahsia di hukum. (2002, March 19). Utusan Malaysia, hlm. 2.

Garvin, D. A. (1988). Managing quality. New York: The Fee Press.

Lassar, W., M., Manolis, C., \& Winsor, R. D. (2000). Service quality perspectives and satisfaction in private banking. Journal of Services Marketing, 14(3), 244-271.

Le Blanc \& Nguyen, (1999). Customers perceptions of service quality in financial institution. International Journal of Bank Marketing, 6(4), 7-18.

Lee, H., Lee, Y., \& Yoo, D. (2000). The determinants of perceived service quality and its relationship with satisfaction. Journal of Services Marketing, 14(3), 217-231.

Levesque, T., \& McDougall, G. H. (1996). Determinants of customer satisfaction in retail banking. International Journal of Bank Marketing, 14(7), 12-20.

McDougall, G. H., \& Levesque, T. J. (1994). Benefit segmentation using service quality dimensions: An investigation in retail banking. International Journal of Bank Marketing, 12(2), 15-23.

Metawa, S. A., \& Almossawi, M. (1998). Banking behavior of Islamic bank customers: Perspective and implications. International Journal of Bank Marketing, 16(7), 299-313.

Muhammad Baqir al-Sadr. (1983). Lamha tamhidiyya 'an mashru' dustar al-jumhuriyya al- Islaminya (pp. 13-20). For more details, see Baram. Beirut (1979). The radical shire opposition movements in Iraq (pp. 107-123).

Nasir, K., Jamal, A., \& Al-Khatib, K. (1999). Islamic banking: Study of customer satisfaction and preferences in Jordan. Journal of Bank Marketing, 17(3), 135-151.

Nguyen, N., \& LeBlanc, G. (1998). The mediating role of corporate image on customers' retention decisions: An investigation in financial services. International Journal of Bank Marketing, 16(2), 52-65.

Nor Mohamed Yakcop. (1996). Sistem kewangan Islam di Malaysia. Kuala Lumpur: Utusan Publications \& Distributors.

Norafifah Ahmad \& Sudin Haron. (2002). Perceptions of Malaysian corporate customers toward Islamic banking products and services. International Journal of Islamic Financial Services, 3(4), 78-88. 
Othman, A., \& Owen, L. (2000). Adopting and measuring customer services quality (SQ) in Islamic bank: A case study in Kuwait Finance House. International Journal of Islamic Financial Services, 3(1), 32-48.

Othman, A., \& Owen, L. (2001). The multi dimensionality of CARTER model to measure customer service quality (SQ) in Islamic banking. International Journal of Islamic Financial Services, 3(4), 125-137.

Parasuraman, A., Berry, L. L., \& Zeithaml, V. A. (1991). Refinement and reassessment of the SERVQUAL scale. Journal of Retailing, $67,420-450$.

Parasuraman, A., Berry, L. L., \& Zeithaml, V. A. (1988). SERVQUAL: A multiple item scale for measuring customer perceptions of service quality. Journal of Marketing, 64, 12-40.

Parasuraman, A., Zeithaml, V. A., \& Berry, L. L. (1985). A conceptual model of service quality and its implications for future research. Journal of Marketing, 49(4), 41-50.

Rahim Abdullah. (1996, 18 Mac). Institusi kewangan dan pelanggan. Utusan Malaysia, hlm. 7

Rust, R. T., \& Zahorik, A. J. (1993). Customer satisfaction, customer retention, and market share. Journal of Retailing, 69(2), 193-215.

Sheikh Muttaqun. (2001, November 3). Perbankan Islam negara diiktiraf dunia. Utusan Malaysia.

Sureshchandar, G. S., Rajendran, C., \& Anantharaman, R. N. (2003). Customer perceptions of service quality in the banking sector of a developing economy: A critical analysis. International Journal of Bank Marketing, 21(5), 233-242.

Uzair, M. (1980). Some conceptual and practical aspects of interesfree banking. In Ahmad, K. (Ed.), Studies in Islamic economic. The Islamic Foundation, Leicester.

Wang, Y., Lo, H. P., \& Hui, Y. V. (2003). The attendants of service quality and product quality and their influences on bank reputation: Evidence from the banking industry in China. Managing Service Quality, 13(1), 72-83.

Zulkifli Abdulah. (2003, Disember 19). Petugas kaunter sukar senyum akan ditukar. Utusan Malaysia, hlm. 11. 


\title{
PENILAIAN PRESTASI MAKLUM BALAS 360 DARJAH DARI PERSPEKTIF ISLAM: SATU TINJAUAN
}

\section{THE 360 DEGREE FEEDBACK APPROACH FROM THE ISLAMIC PERSPECTIVE: AN ANALYSIS}

\author{
AB. AZIZ YUSOF \\ School of Business Management \\ Universiti Utara Malaysia
}

\begin{abstract}
Abstrak
Penilaian prestasi merupakan nadi kepada kehidupan organisasi serta fungsi penting dalam pengurusan sumber manusia. Pelaksanaannya sering diselubungi oleh pelbagai masalah psikososial yang menyebabkan berlakunya konflik, ketidakpuasan, kebimbangan, tekanan, ketandusan upaya dan lainlain. Tanggapan ketidakadilan dalam pelaksanaan dan pengaruh politik pejabat merupakan punca utama kepada permasalahan ini. Bagi berhadapan dengan masalah ini, pelbagai kaedah penilaian prestasi telah diperkenalkan antaranya ialah Maklum Balas 360 Darjah. Walau bagaimanapun, didapati pelaksanaan kaedah ini juga masih lagi terdedah kepada pelbagai kelemahan yang berpunca daripada kesilapan manusia (human errors). Menyedari permasalahan yang dihadapi, kertas kerja ini cuba meneroka pendekatan penilaian prestasi Maklum Balas 360 Darjah daripada perspektif Islam sebagai gantian kepada kaedah konvensional. Kertas kerja ini akan membincangkan justifikasi keperluan kepada pendekatan Islam, pelakupelaku yang terlibat dalam pelaksanaannya serta ciri-ciri yang perlu ada pada pendekatan penilaian prestasi Maklum Balas 360 Darjah daripada perspektif Islam.
\end{abstract}

Kata kunci: Penilaian prestasi, penilaian prestasi Maklum Balas 360 Darjah, penilaian prestasi Maklum Balas 360 Darjah dari perspektif Islam.

\begin{abstract}
Purpose - The purpose of this paper is to discuss the flaw in implementing performance appraisal that raises a number of psycological problems as a result of injustice and political influence during its implementation. To overcome these problems, a new method known as the 360 Degree Feedback
\end{abstract}


was introduced. However, it was found that the implementation of this method still has many weaknesses caused by human errors. In conjunction with the problem, this research seeks to explore the 360 Degree Feedback approach from the Islamic perspective as a substitute for the conventional method. This paper will discuss the justification of using the Islamic approach, the subjects involved in the implementation, and the necessary features of the 360 Degree Feedback from the Islamic perspective.

Design/Methodology/Approach - The study was a library-based research. Therefore, the data collected depended on an extensive review of the literature. The contents of the identified journals, articles and books were rigorously and carefully analysed to enable the conclusion to be made.

Originality/Value - The result of this research can be used as a platform for future researchers to explore it through empirical support. Hopefully, the performance appraisal 360 Degrees Feedback through the Islamic perspective can be a substitude to the traditional approach.

Keywords: performance appraisal, performance appraisal 360 degree feedback, performance appraisal 360 degree feedback from the Islamic perspective.

\section{Pengenalan}

Penilaian prestasi adalah fungsi penting lagi bermasalah dalam pengurusan sumber manusia (Baron \& Kreps, 1999; Ivancevich, 2001; Chen \& Kuo, 2004). Kajian-kajian terdahulu membuktikan pelbagai kaedah pelaksanaan berasaskan satu sumber telah menimbulkan pelbagai masalah psikososial antaranya menyebabkan ketidakpuasan kerja, konflik, kebimbangan, rasa tertekan dan ketandusan upaya. Situasi sebegini menyebabkan banyak pihak menerima penilaian prestasi sebagai fungsi yang menimbulkan pelbagai kesulitan (Ivancevich, 2001; Roberts, 1998; Derven, 1990; Taylor, Tracy, Renard, Harisson \& Carroll, 1995).

Bagi berhadapan dengan masalah ini, pendekatan penilaian prestasi yang datang dari pelbagai sumber telah diperkenalkan antaranya penilaian prestasi Maklum Balas 360 Darjah (Edwards \& Ewen, 1996). Thach (2002) melihat kaedah ini sebagai program pembangunan pengurusan yang paling cepat berkembang terutama dalam organisasi multinasional. Sungguhpun begitu, didapati pelaksanaannya turut diselubungi oleh pelbagai masalah terutama berpunca daripada kesilapan manusia (human errors) seperti berlaku pilih kasih (Comerford, 2002; Albright \& Carr, 1997), stereotaip 
(Robbins, 2005; Rudner, 1992) dan politik pejabat (Deondra, 2006; Zivnuska, Kacmar, Witt, Carlson, \& Bratton (2004). Akibatnya, banyak pihak mempersoalkan keberkesanan pelaksanaannya (Wimer, 2002). Rentetan daripada ini O'Reilly (1994) telah menyuarakan kebimbangannya apabila mendapati kaedah ini cukup menakutkan pihak yang dinilai (ratees). Hal ini kerana maklumat yang diperoleh bukan sahaja bersifat peribadi tetapi boleh menjejaskan reputasi pekerja yang dinilai. Bagi beliau adalah sukar untuk menerima kritikan sebagai sesuatu yang konstruktif apabila kebanyakan penilai menyatakan tugas pekerja yang dinilai adalah sangat tidak terurus sehingga boleh menjejaskan ketepatan pemarkahan yang sepatutnya diterima.

Menyedari tentang permasalahan ini, Moses, Hollenbeck dan Sorcher (1993) telah mengenal pasti lima kelemahan utama yang sering berlaku dalam pelaksanaan kaedah ini. Pertama, kaedah ini telah dikritik kerana terlalu bergantung kepada generalisasi umum ke atas ciri-ciri atau sifat-sifat individu pekerja yang dinilai. Kedua, terlalu bergantung kepada keterhadan atau tiada satu kerangka rujukan dalam membuat sesuatu pertimbangan (judgments). Ketiga, kaedah ini juga dikritik kerana bergantung kepada penerangan yang tidak lengkap. Keempat, terdapatnya kebimbangan terhadap kemampuan penilai untuk menterjemahkan gelagat dan pencapaian ke dalam bentuk angka pengkadaran. Dan yang terakhir, kaedah ini dilihat terlalu bergantung kepada sistem pembentukan pengkadaran untuk tujuan pentadbiran bukan untuk penentuan ganjaran.

Akibat daripada pelbagai masalah yang dihadapi telah membangkitkan rasa ketidakpuasan dalam kalangan pengurus dan pekerja terhadap pelaksanaannya (Dacri, 2005; Roberts, 1998; Edwards, 1989) kerana kesan akhirnya telah menyebabkan berlakunya pelbagai kesulitan (Latham \& Wexley, 1994). Menyedari permasalahan yang dihadapi mendorong pengkaji untuk membuat penerokaan terhadap kemampuan Islam sebagai gantian kepada pelaksanaannya. Bagi pengkaji, pendekatan Islam dalam mengemukakan jalan penyelesaian kepada permasalahan ini perlu diterokai setelah pelbagai pendekatan telah diambil tetapi terus terbukti menemui kebuntuan.

\section{Kenapa Perlu Pendekatan Islam dalam Pelaksanaan Penilaian Prestasi Maklum Balas 360 Darjah?}

Pendekatan Islam dalam pengurusan termasuk pelaksanaan penilaian prestasi Maklum Balas 360 darjah telah menimbulkan minat banyak 
pihak untuk mendalaminya. Bagi Kazmi dan Ahmad (2006) perkara ini didorong oleh peningkatan minat terutama dalam kalangan ahli akademik untuk melihat model pengurusan yang terkeluar daripada kerangka model pengurusan Amerika (American management models) seperti melihat model pengurusan dari perspektif keagamaan seperti Confucius, Hindu, Kristian dan Islam. Gesaan sebegini turut dikemukakan oleh Abbas, Gibbs dan Camp (2000) yang menjelaskan betapa perlunya ketiga-tiga ajaran agama wahyu iaitu Islam, Kristian dan Judaisme diambil kira dalam pengurusan organisasi telah membuktikan bahawa kepercayaan dan nilai-nilai agama mempunyai kesan yang signifikan ke atas tingkah laku pekerja termasuk aspek kepuasan kerja (King \& Williamson, 2005), gaya kepimpinan (Reave, 2005) dan persoalan berkaitan dengan etika (Weaver \& Agle, 2002).

Sementara itu, bagi Junaidah (2009), pendekatan Islam perlu ditonjolkan dalam pengurusan organisasi di era ajaran agama mempengaruhi kehidupan dan pekerjaan ketika ini. Bagi beliau pendekatan Islam dalam pengurusan merupakan satu keperluan kerana pekerja yang beragama Islam merupakan komponen terbesar dalam sektor awam di Malaysia. Pendekatan Islam dalam pengurusan juga didapati selari dengan langkah-langkah kerajaan untuk mengislamisasikan agenda pentadbiran dan pengurusan di Malaysia (Endot, 1995).

Khursyid (1991) pernah menyatakan bahawa menjadi satu keharusan bagi umat Islam untuk melihat kembali semua pendekatan pengurusan konvensional yang hanya memberi penekanan kepada peningkatan keuntungan sebagai satu-satunya pengukur kepada pencapaian kerja pekerja dan kemajuan organisasi. Sungguhpun begitu, Islam sebagai agama syumul tidak sekali-kali mengesyorkan pendekatan, mekanisme dan kaedah pengurusan secara kovensional dihapuskan sepenuhnya, melainkan kegiatan sedemikian jelas bertentangan dengan falsafah dan ajaran Islam. Sejarah telah membuktikan bahawa kerajaan Islam mewarisi pengetahuan dan kemahiran dengan menambah pembaharuan penting yang diperoleh dari luar seperti Timur Tengah kuno, Yunani, Parsi dan India (Donald, 1993). Ini adalah kerana asas utama falsafah dan ajaran Islam ialah memberi kesejahteraan dan kebahagiaan dalam membangunkan kehidupan. Sebagai agama wahyu, Islam menyediakan kerangka ajaran yang menyeluruh meliputi segenap aspek dalam kehidupan manusia termasuk kehidupan berorganisasi. 
Bagi Islam, aspek kehidupan berorganisasi diterima sebagai mekanisme yang membolehkan manusia memperoleh dwi kejayaan iaitu dalam bidang kebendaan dan juga kerohanian. Kedua-dua aspek ini amat penting kepada kehidupan di dunia dan juga di akhirat (AlBuraey, 2001). Kedua-dua aspek telah mempengaruhi dorongan dan komitmen umat Islam untuk memberi yang terbaik kepada segenap lapangan yang disertai. Sungguhpun begitu, sehingga kini kajian mengenai sumbangan Islam terhadap pelaksanaan penilaian prestasi Maklum Balas 360 Darjah masih belum diterokai. Mudah-mudahan hasil daripada kajian ini mampu menyediakan satu gantian kepada pengamal dan ahli-ahli akademik bahawa terdapatnya jalan penyelesaian iaitu berlandaskan kepada ajaran Islam terhadap permasalahan yang dihadapi. Berkaitan dengan ini, penilaian prestasi Maklum 360 Dajah perlu diteroka dan diperjelaskan dari kaca mata atau tasawur Islam.

\title{
Tasawur Islam dalam Penilaian Prestasi Maklum Balas 360 Darjah
}

Temuan kajian terdahulu mendapati pelbagai pihak menunjukkan kesangsian mereka terhadap keberkesanan pelaksanaan penilaian prestasi termasuk kaedah Maklum Balas 360 Darjah antaranya Napier dan Latham (1986) dan Banks dan Murphy (1985). Bagi mereka kajian-kajian yang dilakukan hanya mampu memberi sedikit manfaat termasuk kepada pelaksanaan sistem penilaian prestasi Maklum Balas 360 Darjah yang diterima sebagai mekanisme penting dalam menilai prestasi kerja pekerja. Hakikat permasalahan yang dihadapi telah diakui oleh Wiese dan Buckley (1998) apabila mereka menyatakan seperti berikut:

\begin{abstract}
"Until then, businesses will continue to use performance appraisal systems in use today, and hopefully through Divine Providence, the best people will generally rise to the top." (ms. 247).
\end{abstract}

(Sehingga kini, organisasi akan terus menggunakan penilaian prestasi sebagaimana yang digunakan pada hari ini, dan dengan penuh harapan melalui kehematan KeTuhanan, pekerja-pekerja terbaik akan berjaya naik pangkat).

Kehematan ketuhanan sebagaimana yang telah mereka nyatakan merupakan satu pengakuan jujur kerana menyedari kegagalan dan pelbagai permasalahan yang dihadapi semasa dan selepas pelaksanaan penilaian prestasi konvensional termasuk kaedah 
Maklum Balas 360 Darjah. Satu sudut kehematan ketuhanan yang mereka cadangkan adalah selari dengan tuntutan Islam. Walau bagaimanapun, dari sudut pendekatan keTuhanan lain yang dikemukakan berbeza daripada pendekatan keTuhanan yang dituntut oleh Islam. Mengikut Syed Muhammad Al-Naquib (1978) dan Jamal (2002), ketuhanan yang mereka maksudkan adalah dalam kerangka sekularisme barat yang hanya menumpukan kepada aspek ritual, individualistik dan melihat urusan pengurusan organisasi secara terpisah. Sebaliknya, Islam melihat aspek ini dari dua dimensi yang tercantum iaitu aspek kehidupan dunia dan kehidupan di hari akhirat (Ali, 1979). Seterusnya, Sayyid Qutb (1983) memperkukuhkan pandangan ini dengan menjelaskan ajaran Islam tidak memisahkan manusia antara jasad dengan roh serta tidak membezakan antara aspek intelektual dengan kerohanian. Oleh itu, pelaksanaan penilaian prestasi Maklum Balas 360 Darjah perlu dilihat dari aspek yang lebih menyeluruh.

Syed Muhammad Naquib (2005), pernah menyatakan bahawa Islam melihat kehidupan ini meliputi alam dunia dan akhirat, di mana alam kehidupan dunia mesti dikaitkan dengan kehidupan akhirat. Manakala bagi A. Qadir (1981), hukum-hukum yang dibawa oleh Islam meliputi dua aspek penting iaitu pertama melibatkan pertalian dengan masalah akhirat yang melibatkan aspek-aspek akidah dan ibadat. Manakala kedua, berkaitan dengan masalah negara, masyarakat, hubungan sesama manusia yang meliputi masalahmasalah muamalat, munakahat, sahsiah dan lain-lain. Jelas beliau lagi, Islam adalah agama yang seimbang antara tuntutan akhirat dengan tuntutan dunia. Islam juga menyuruh umatnya supaya sentiasa berakhlak mulia dengan membebaskan diri daripada sebarang bentuk diskriminasi dalam menjalankan urusan berorganisasi (Bilal, Ayesha, \& Zareen, 2010).

Menyedari hakikat kepentingan Islam dalam pengurusan maka tasawur Islam hendaklah diterima sebagai suatu sistem yang lengkap meliputi aspek kerohanian, politik, ekonomi dan sosial. Tasawur Islam juga perlu diterima secara bersepadu dalam menyusun atur cara hidup manusia (Abu Ala, 1991). Melalui pengertian dan pemahaman yang menyeluruh mengenai tasawur Islam akan dapat memberi impak dan kesan yang positif ke atas setiap tindakan yang diambil oleh pengurus, pekerja dan pihak-pihak lain yang berkepentingan yang terlibat dalam pelaksanaan penilaian prestasi Maklum Balas 360 Darjah. Semua pihak hendaklah sama-sama tunduk dan patuh kepada perintah Allah SWT sama ada berbentuk suruhan atau larangan. 
Dalam konteks ini tasawur Islam diterima sebagai satu fahaman yang hakiki mengenai Islam bertujuan untuk memperjelaskan secara keseluruhan prinsip asas Islam secara benar dan menyeluruh sehingga menjadi tunjang kepada pandangan hidup yang sebati dengan kehidupan seseorang Muslim (Muhammad Syukri, 2003). Sehubungan ini, pelaksanaan penilaian prestasi Maklum Balas 360 Darjah hendaklah selari dengan tuntutan ajaran yang telah dibawa oleh Islam. Seterusnya, Muhammad Syukri (2003) berpendapat bahawa untuk memenuhi tuntutan tasawur Islam, segala tindakan dan keputusan yang diambil hendaklah berpaksikan kepada tiga prinsip utama iaitu pertama menerima dengan sepenuh keyakinan Allah SWT adalah pencipta, kedua, manusia adalah makhluk Allah SWT dan ketiga segala sumber di mayapada ini juga merupakan makhluk ciptaan-Nya. Bagi beliau, semua makhluk ini hendaklah tunduk dan patuh kepada hukum-hakam yang telah ditetapkan oleh Allah SWT.

Sebagai dorongan utama, ajaran Islam telah menyediakan ganjaran pahala dan dosa di atas ketundukan dan kepatuhan hamba-Nya yang diakui sebagai mekanisme untuk mengawal dan mendorong manusia untuk melakukan yang terbaik. Setiap perbuatan dan keputusan yang dilakukan dengan penuh ikhlas telah dijanjikan dengan ganjaran di dunia juga ganjaran di akhirat. Dalam konteks pelaksanaan penilaian prestasi, penilai yang bertindak selari dengan ajaran Islam akan diberikan ganjaran yang setimpal dengan input yang telah disumbangkan yang dilakukan semata-mata untuk mendapat keredaan Allah serta diterima sebagai satu ibadah (Yousef, 2001). Mereka yakin, selain daripada menilai, mereka juga turut dinilai oleh Allah SWT terhadap setiap keputusan dan tindakan yang telah dilakukan.

Seterusnya, bagi Zahid dan Pervaiz (2004) Islam melihat penyelesaian kepada sesuatu permasalahan bukan hanya berpunca dari luaran (extrinsic) dan permukaan (surface) tetapi memerlukan keprihatinan yang tinggi terhadap dimensi keTuhanan kerana ia akan mempengaruhi tindak tanduk seseorang terhadap pekerjaan yang dilakukan. Lebih-lebih lagi adalah menjadi matlamat pengurus dan pekerja untuk memberi dan juga menerima yang terbaik menurut perspektif Islam.

Untuk mencapai matlamat ini, satu pendekatan baru berkaitan dengan pengurusan organisasi perlu dirangka di mana pengisian dan pelaksanaan yang lebih konkrit dalam bentuk dasar, program dan strategi perlu dibentuk (Wan Liz Ozman, 1996). Dengan lain 
perkataan, pendekatan pengurusan yang lebih menyeluruh selari dengan tuntutan Islam perlu dilaksanakan sebagai pendekatan gantian kepada pendekatan pengurusan konvensional (Mohd Affandi, 1992). Sejajar dengan tuntutan ini, Mansor dan Ali (1998) pernah menyatakan bahawa sudah sampai masanya amalan pengurusan organisasi di Malaysia diterokai dan dilihat dari kaca mata agama Islam.

Pandangan ini selari dengan pandangan Ali (1990) dan disokong oleh Muhammad Syukri Salleh (2002). Bagi mereka, pelaksanaan agenda pengurusan organisasi perlu sejajar dengan tunggak dan prinsip yang telah ditetapkan oleh Islam. Muhammad Syukri (2002) berpendapat kesyumulan pengurusan berteraskan Islam tentunya tidak boleh lepas lari dari bertunjangkan kepada jalinan dengan Allah dan jalinan sesama manusia yang perlu diterima sebagai ilmu fardhu 'ain. Dalam konteks ini, pengurusan organisasi ini akan hanya diterima sebagai tuntutan fardhu 'ain berteraskan Islam jika berjaya memenuhi tuntutan ketiga-tiga hubungan ini (Muhammad Syukri, 2002).

Perkara sama pernah diberi tumpuan oleh Maududur Rahman dan Muhammad Al-Buraey (1992) yang menurut mereka pendekatan pengurusan tradisional lebih terdorong kepada pertimbangan ekonomi yang berobjektifkan keuntungan semaksimum yang mungkin (profit maximization) dengan membelakangkan nilainilai akhlak. Perkara ini diakui kebenarannya apabila Mondy (2010) menyatakan penilaian prestasi merupakan proses yang berorientasikan matlamat bagi memastikan organisasi mendapatkan pulangan produktiviti yang maksimum. Joni Tamkin Borhan, (2008) menyatakan pengurusan merupakan konsep yang multidimensi yang komprehensif mengandungi persoalan ekonomi dan bukan ekonomi serta melibatkan aspek-aspek boleh diukur secara kuantitatif dan kualitatif. Dorongan ini menyebabkan pengurus meletakkan keuntungan mengatasi segala-galanya sehingga sanggup membelakangkan kemanusiaan dan keTuhanan. Ini bertentangan dengan ajaran Islam yang lebih terdorong kepada kehendak kerohanian yang berobjektifkan keuntungan yang berpadanan (reasonable profit). Tayeb (1997:354) pernah menjelaskan keadaan ini sebagaimana berikut:

"Islam, unlike many other religions, is an all-encompassing creed, it governs every aspect of life, public and private, political and economic, and as such is relevant to business activities." 
(Islam, tidak seperti agama-agama yang lain, merangkumi semua sistem, mengawal segenap aspek kehidupan, awam dan persendirian, politik dan ekonomi, begitu juga sesuai dengan aktiviti perniagaan)

Dari sini dapatlah difahami bahawa pengurusan berteraskan Islam meliputi segenap ruang lingkup kehidupan sama ada memenuhi tuntutan fizikal, akal dan rohani yang bertujuan untuk menjamin kesejahteraan kehidupan manusia sejagat. Ajaran yang dibawa oleh Islam telah berjaya meruntuhkan tembok yang memisahkan antara seorang manusia dengan manusia yang lain. Antara tembok yang telah berjaya diruntuhkan ialah ketaksuban kepada bangsa, tanah air, keturunan, warna kulit, pangkat dan status (Danial Zainal Abidin, 2003). Keadaan ini menyebabkan munculnya segolongan dalam organisasi yang sanggup menafikan hak-hak yang wajar diperoleh oleh pekerja-pekerja yang lain. Antara hak-hak berkenaan adalah hak untuk menjaga agama, nyawa, akal, keturunan dan harta benda (Yusof Qaradawi, 1985).

Hak-hak ini didapati bersifat sejagat yang mana bagi Duran (1997) ia melibatkan semua anggota dalam kehidupan berorganisasi. Seterusnya, beliau menjelaskan lagi bahawa prinsip pengurusan berorganisasi dalam Islam bukan hanya melarang tindakan yang boleh memudaratkan orang lain tetapi juga memudaratkan diri sendiri. Prinsip ini boleh dijadikan landasan yang terbaik untuk memastikan tindakan dan keputusan yang diambil tidak mendatangkan kemudaratan kepada diri sendiri dan juga orang lain. Dengan kata lain, pelaku-pelaku utama dalam organisasi hendaklah bersedia membangunkan kehidupan berorganisasi di atas dasar keadilan (Surtahman, 1993), dengan matlamat utama untuk memperoleh keredaan Allah SWT serta mengembalikan fungsi manusia sebagai hamba dan khalifah-Nya (Muhammad Syukri, 2002).

Sungguhpun begitu, Muhammad Syukri (2002) mendapati perbincangan mengenai pengurusan organisasi berlandaskan Islam adalah masih baru dan ia perlu terus digilap dan diperkemaskan. Bagi beliau terdapat dua langkah yang boleh memperkemaskan ilmu mengenai pengurusan Islam iaitu pertama dengan membentuknya dari perspektif yang lebih holistik dan kedua melengkapkannya dengan semua aspek pengurusan secara lebih menyeluruh iaitu bermula dari aspek teoritis sehingga kepada aspek-aspek pelaksanaannya. 
Bagi menyokong usaha sedemikian, Al-Buraey (2001) telah mengenal pasti lima faktor utama yang mendorong kepada pembinaan model dalam pengurusan dari perspektif Islam iaitu pertama, keperluan umat Islam untuk memahami teori, nilai dan amalan berkaitan dengan kehidupan berorganisasi. Kedua, umat Islam hendaklah kembali kepada prinsip asas pengurusan yang mengutamakan elemen semangat, sejarah dan kehidupan yang diamalkan sejak zaman Nabi Muhammad SAW dan para Khalifah.

Faktor ketiga adalah peranan umat Islam sendiri yang telah membuktikan keyakinan untuk mengamalkan kaedah ini untuk mengembalikan semula kegemilangan tamadun Islam. Faktor keempat didorong oleh pengalaman yang pernah dialami oleh umat Islam melalui pelbagai model pengurusan konvensional telah terbukti gagal untuk membawa kemakmuran kepada kehidupan mereka. Bahkan ramai dalam kalangan intelektual Barat sendiri yang telah membuat pengakuan secara terbuka mengenai kegagalan ini sehingga tercetusnya fenomena baru yang mahukan pendekatan agama kembali dipersadakan dengan apa yang telah diistilahkan sebagai the global resurgence of religion (Azzam \& Esposito, 2000).

Faktor terakhir yang mendorong pembinaan model pengurusan Islam adalah penciptaan model Islam daripada sumber utama pengurusan Islam. Sungguhpun begitu, ia hendaklah disesuaikan dengan pemikiran kontemporari dengan menggunakan teknik, alat dan teknologi kontemporari serta penglibatan pakar dan pengamal kontemporari melalui khidmat nasihat dan bantuan. Bertolak dari sini, kajian secara teoritis perlu dilakukan terhadap pendekatan penilaian prestasi Maklum Balas 360 Darjah dari perspektif Islam.

\section{Pendekatan Penilaian Prestasi Maklum Balas 360 Darjah dari Perspektif Islam}

Mengikut ajaran Islam, perbincangan mengenai penilaian prestasi Maklum Balas 360 Darjah bukan merupakan sesuatu perkara yang baharu. Ia telah diperkenalkan seawal kejadian manusia itu sendiri. Bagi memastikan manusia bertindak selari dengan tuntutan-Nya, Allah SWT telah melantik dua malaikat iaitu Raqib dan 'Atid untuk mencatat segala amal perbuatan manusia yang dilakukan secara berterusan, menyeluruh dan bebas daripada sebarang bentuk kelalaian. Firman Allah SWT yang bermaksud: 
"Bagi setiap manusia ada malaikat-malaikat bertugas silih berganti dari hadapannya dan dari belakangnya, yang mengawas dan menjaganya (daripada sesuatu bahaya) dengan perintah Allah....."

(Surah al-Ra'd 13: 11)

Natijah daripada amal perbuatan mereka akan diberikan ganjaran pahala atau dosa yang bakal melayakkan mereka untuk memasuki syurga atau neraka Allah SWT hasil daripada setiap pekerjaan yang dilakukan bersaksikan anggota mereka sendiri. Firman Allah yang bermaksud:

"Bahkan manusia itu, (anggotanya) menjadi saksi terhadap dirinya sendiri"

(Surah al-Qiyāmah 75: 14)

Bahkan di hari pengadilan segala anggota milik manusia akan menjadi saksi terhadap segala pekerjaan yang mereka lakukan semasa menjalani kehidupan di dunia. Dalam Islam, urusan pekerjaan telah diberi penekanan seawal sejarah kejadian manusia itu sendiri. AlQur'an pernah menceritakan dua orang anak kepada Nabi Adam a.s yang telah mempelopori dua bidang pekerjaan utama yang terdapat hari ini iaitu Habil mempelopori lapangan pertanian dan Qabil mempelopori lapangan ternakan sebagaimana firman Allah SWT yang bermaksud:

"Ceritakanlah (wahai Muhammad) kepada mereka kisah dua
oranganakAdam (Habildan Qabil) yang telahberlakudengan
sebenarnya. Iaitu ketika mereka berdua mempersembahkan
korban (untuk mendampingkan diri kepada Allah), lalu
diterima korban salah seorang antara kedua-dua mereka
(Habil) dan tidak diterima (korban) daripada yang
lain (Qabil). Qabil berkata, "Sesungguhnya aku akan
membunuhmu!" (Habil) menjawab, "Sesungguhnya Allah
hanya menerima (korban) daripada orang yang bertaqwa."

(Surah al-Mā'idah 5: 27)

Ayat di atas telah menjelaskan bagaimana Allah SWT menilai prestasi kerja yang telah dibuktikan oleh Qabil dan Habil. Dalam penilaian berkenaan, Allah SWT telah mengambil kira kualiti korban 
yang telah dibuktikan oleh kedua-dua mereka dan keikhlasan dan ketaqwaan yang telah ditunjukkan. Ali (2005) menyatakan penilaian prestasi dalam Islam perlu berdasarkan ajaran Al-Quran dan Sunnah Rasulullah SAW. Bagi tujuan ini, Islam telah menyediakan pendekatannya sendiri dalam penilaian prestasi Maklum Balas 360 Darjah. Pendekatan yang disediakan adalah untuk memastikan pelaksanaannya dapat dilaksanakan selari dengan syariat yang telah ditetapkan. Setiap penilai perlu menerima syariat sebagai pendorong, petunjuk dan pembimbing semasa melakukan penilaian prestasi yang telah diamanahkan. Penilai perlu meletakkan sepenuh keyakinan bahawa Islam merupakan agama yang paling kontemporari dan sesuai pada semua tempat, mampu menyelesaikan segala masalah, dalam pelbagai situasi dan pada sepanjang zaman. Mereka perlu sedar objektif utama agama Islam adalah untuk meningkatkan tahap kehidupan manusia agar lebih selesa dan gembira (Afzal-UrRahman, 1994). Seterusnya, Islam menyarankan kepada umatnya agar selalu menilai atau muhasabah diri sekiranya ingin berjaya di dunia dan di akhirat.

\section{Pendekatan Tiga Segi Pelaku Penilaian Prestasi Maklum Balas 360 Darjah}

Pendekatan Tiga Segi Pelaku penilaian prestasi Maklum Balas 360 Darjah dari perspektif Islam cuba mengetengah satu pendekatan yang terkeluar daripada pendekatan lazim. Dalam konteks ini, pelaku utama adalah manusia (Muhammad Syukri, 2001; 2002). Mengikut beliau, manusialah yang bakal terlibat dan mereka jugalah yang bakal menerima kesan daripada usaha-usaha yang telah dilakukan. Dalam konteks pelaksanaan penilaian prestasi Maklum Balas 360 Darjah manusia yang terlibat dikategorikan kepada tiga golongan iaitu pengurus atasan, penilai dan pihak-pihak yang dinilai. Ketiga-tiga golongan ini perlu memainkan peranan secara simbiosis iaitu saling sokong-menyokong, saling bantu-membantu dan saling bertindak sebagai check and balance.

Ketiga-tiga pelaku ini perlu memastikan kesan akhir daripada pelaksanaan mampu memenuhi tuntutan secara menegak mereka dengan Allah SWT (hablumminallah), tuntutan secara mendatar sesama manusia (hablumminannas) dan juga hubungan dengan alam (hablumminalalamin) dengan satu tujuan iaitu memperoleh keredaan daripada Allah SWT. 
IJMS 20 (1), 203-230 (2013)

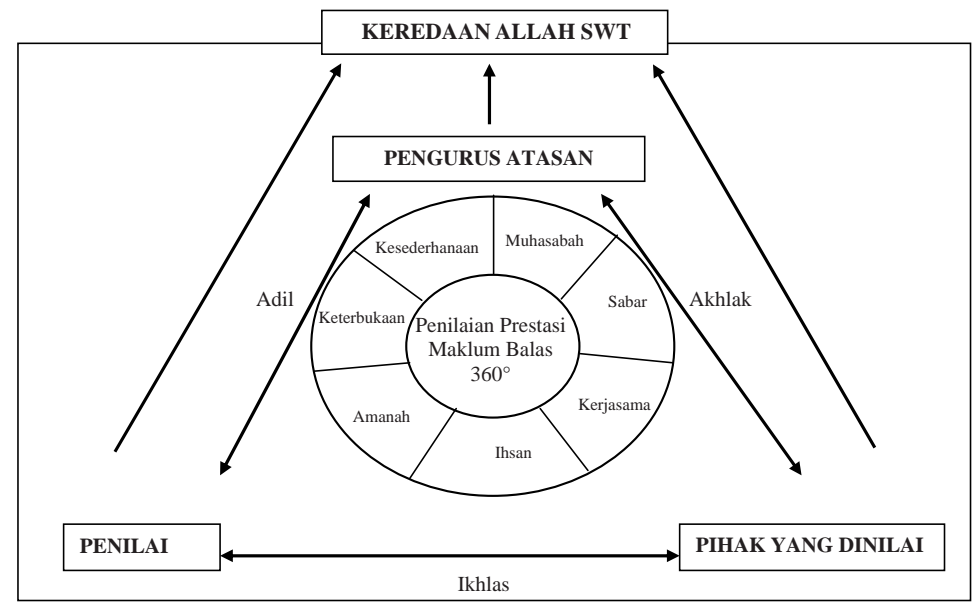

Rajah. Pendekatan tiga segi penilaian prestasi maklum balas 360 darjah dari perspektif Islam.

Pelaku-pelaku ini perlu dilihat sebagai manusia yang telah diberi kelebihan oleh Pencipta untuk memobilisasi sumber bagi memastikan penilaian yang dilaksanakan berdasarkan ajaran al-Quran, Sunnah Rasulullah SAW, qias dan ijma' ulama (Ali, 2005). Sebagai manusia, mereka bertanggungjawab atas apa yang dilakukannya dan tiada siapa yang bertanggungjawab atas kesilapan orang lain dan pencapaian mereka akan dinilai secara berterusan dan menyeluruh.

Untuk memastikan pencapaian kerja yang terbaik, pelaku-pelaku ini perlu memiliki keterampilan diri yang baik, pemikiran yang matang, ketenangan dalam mengurus nafsu dan kemantapan rohani sehingga diyakini pihak-pihak yang menilai dan dinilai. Mereka perlu sentiasa berusaha untuk mengubah kualiti kehidupan berorganisasi ke arah yang lebih baik dengan mengubah proses dan juga hasil kerja dengan mengubah sikap, cara berfikir, cara melaksanakan tugas sehingga berjaya memartabatkannya sebagai satu ibadat.

Mereka akan lebih berhati-hati dalam apa jua perkara yang akan mereka lakukan agar tidak tergelincir daripada landasan yang telah ditetapkan (Endang, 1986). Afzal-Ur-Rahman (1994) mengingatkan supaya pelaku perlu sedar bahawa matlamat utama memakmurkan organisasi adalah untuk meningkatkan kualiti kehidupan berorganisasi 
agar pekerja gembira dan selesa dengan tugas yang mereka laksanakan (Rahmad Sukor \& Gooi, 2005). Justeru, segala tindak tanduk mereka hendaklah menjurus ke arah mencapai kemakmuran organisasi yang hakiki.

Untuk mencapai tujuan ini, pelaku-pelaku perlu mengutamakan keadilan dalam setiap tindak-tanduk dan keputusan yang diambil. Menurut Khaliq (2004), keadilan Islam berdasarkan kepada tiga prinsip utama iaitu adil, insaf dan ihsan. Dengan mematuhi prinsipprinsip ini akan memberi jaminan kepada dua bentuk ganjaran iaitu ganjaran kebendaan dan ganjaran yang berbentuk superfisial. Melalui ganjaran yang berbentuk superfisial atau ukhrawi akan mendorong pelaku untuk terus memperingkatkan kualiti penilaian pencapaian kerja yang dilakukan.

\section{Kriteria Asas Pelaksanaan Penilaian Prestasi Maklum Balas 360 Darjah dari Perspektif Islam}

Bagi memastikan pelaksanaan penilaian prestasi Maklum Balas 360 Darjah dapat dilakukan dengan jayanya, setiap penilai perlu memenuhi kriteria-kriteria berikut ialah:

\section{Berakhlak}

Nilai akhlak yang mulia merupakan satu ciri keindahan yang terdapat dalam kehidupan manusia. Menurut Mustaq (2001) akhlak merujuk kepada sifat kemanusiaan yang tinggi dan mulia. Ciri ini jugalah yang membezakan antara manusia yang berperadaban dengan manusia yang jahil. Bagi Hassan (1998), kehebatan seseorang tidak sahaja diukur dengan kemajuannya tetapi juga keupayaannya mengamalkan budi bahasa dan budi pekerti yang mulia. Akhlak diterima sebagai cetusan yang terpancar dari amalan yang sebati di dalam jiwa seseorang. Malahan ia juga dijadikan sebagai salah satu tunjang penting yang perlu ada dalam pelaku-pelaku penilaian prestasi Maklum Balas 360 Darjah.

Al-Quran telah menggariskan beberapa amalan yang melambangkan kemuliaan budi yang perlu dimiliki oleh setiap pelaku. Antaranya ialah Rasulullah SAW telah mewajibkan agar seseorang sentiasa berakhlak mulia seperti yang tua perlu dihormati dan yang muda perlu disayangi. Rasulullah SAW pernah bersabda yang bermaksud: 
"Sesiapa yang tidak menyayangi kanak-kanak dan tidak menghormati orang yang lebih tua, maka ia bukan daripada golongan kami."

(Hadis Riwayat Bukhari)

Sebaliknya, Islam melarang umatnya saling berburuk sangka, memfitnah, mengumpat, mengeji, mencari keaiban orang lain, merendahkan orang lain, berlagak sombong, angkuh, riak dan membangga diri. Semua larangan ini dijelaskan oleh Allah SWT di dalam ayat:

"Wahai orang-orang yang beriman! Janganlah sesuatu puak (dari kaum lelaki) mencemuh dan merendah-rendahkan puak lelaki yang lain. Mungkin puak yang dicemuh itu lebih baik daripada mereka. Dan janganlah pula sesuatu puak dari kaum perempuan mencemuh dan merendah-rendahkan puak perempuan yang lain. Mungkin puak yang dicemuh lebih baik daripada mereka. Dan janganlah kamu menyatakan keaiban setengah yang lain..."

(Surah al-Hujurāt 49: 11).

Mereka perlu membantu pekerja agar menambak baik pencapaian kerja dengan terus meningkatkan mutu kerja dan produktiviti. Keduadua aspek ini mampu dilaksanakan dengan memberi penumpuan kepada prinsip kesempurnaan (al-Itqan), pembaharuan (at-tajdid) dan inovasi (al-ikhtikar) (Wan Liz Ozman, 1996).

Memiliki akhlak yang mulia akan dapat meletakkan pelaku disenangi oleh pelbagai pihak. Keintiman antara mereka akan lebih akrab kerana mereka lebih bersikap bertanggungjawab, bertolak ansur dan saling memahami. Pelaku yang berakhlak mulia dan amanah amat disenangi oleh Allah SWT. Mereka akan bertindak secara konsisten dalam menjalankan tugas dengan cekap dan penuh tanggungjawab kerana ikatannya hanyalah kepada Allah SWT. Ketinggian akhlak yang didokong oleh ketakwaan mereka terhadap Allah SWT akan menjadikan mereka seorang yang bersedia untuk memberi perkhidmatan untuk kebaikan pekerja yang dinilai dengan tujuan mendapat keredaan dan mengelakkan dari kemurkaan Allah SWT.

\section{Berlaku Adil}

Penilai perlu mengutamakan keadilan organisasi semasa melaksanakan penilaian prestasi Maklum Balas 360 Darjah. Menurut Yusof (1983), berlaku adil sepenuhnya bukan hanya untuk dilihat sebagai adil oleh 
pihak lain tetapi adalah untuk membuktikan keadilan dilakukan dengan penuh keikhlasan dari segi hati dan nurani hanya untuk memperoleh ganjaran keredaan daripada Allah SWT. Menyedari kepentingan keadilan dalam Islam, Mohamed Barween (2002) menyatakan aspek ini merupakan antara sepuluh hak asasi manusia yang perlu dipenuhi dan dihormati. Hak-hak lain yang dimaksudkan ialah hak manusia untuk mendapat kehidupan, hak manusia untuk mendapat ketenangan, hak manusia untuk membuat pilihan, hak manusia untuk mendapat kesamarataan di bawah undang- undang, hak manusia untuk mendapat asas kepada keperluan kehidupan, hak manusia untuk mendapat kebebasan bersuara, hak manusia untuk bersendirian, hak manusia untuk mendapat hak milik dan hak manusia untuk memprotes.

Begitu juga, dalam melaksanakan penilaian prestasi Maklum Balas 360 Darjah memerlukan penilai untuk membuat keputusan yang berkaitan dengan pengagihan tugas dan penentuan ganjaran yang perlu dilakukan dengan seadil yang mungkin. Hal ini kerana keadilan perlu diterima sebagai suatu amanah yang patut dipenuhi (Azman, 2001). Lantaran daripada itu, keadilan Islam dalam pelaksanaan penilaian prestasi Maklum Balas 360 Darjah bertujuan untuk memberikan kesaksamaan kepada semua pekerja. Perkara bertepatan dengan ajaran Islam yang mengiktiraf perbezaan jantina, etnik, warna kulit, bentuk fizikal, personaliti, bahasa dan kebudayaan kerana perbezaan berkenaan dijadikan oleh Allah untuk tujuan saling kenal mengenali antara satu dengan yang lain (Mohd Nasir, 2005).

Pengurus perlu sentiasa menegakkan keadilan. Ini kerana mengutamakan keadilan adalah serlahan daripada sifat Allah SWT iaitu Maha Adil. Keadilan manusia akan mengelak mereka daripada melakukan kezaliman dan penindasan organisasi dan ummah. Yang pasti semua pihak mahukan jaminan keadilan dengan memenuhi hak-hak yang layak mereka diperoleh. Hal ini kerana mengikut ajaran Islam, perbezaan yang bersifat lahiriah atau dibuat, membawa kepada perbezaan kemanusiaan seperti membezakan manusia dari segi bahasa, keturunan, warna kulit, kelas dan kehidupan sosial amatlah dilarang sama sekali. Apabila manusia dipandang berbeza dari segi status, pangkat, warna kulit dan bahasa secara tidak langsung keadilan terhadap mereka pun berbeza-beza juga (Sidi, 1986). Kesamaan manusia di sisi Allah SWT menyebabkan manusia berada pada taraf yang sama, mendapat hak yang sama rata dan keadilan yang sama. 
IJMS 20 (1), 203-230 (2013)

\section{Sentiasa Ikhlas}

Sesuatu tugas juga mestilah dilaksanakan dengan ikhlas dan jujur dan bukannya bertujuan untuk kepentingan diri sendiri atau tujuantujuan lain selain daripada mengharapkan keredaan daripada Allah SWT. Rasulullah saw pernah bersabda yang bermaksud:

"Sesungguhnya tidak dikira amalan kecuali dengan niat dan tiap-tiap orang akan mendapat apa yang diniatkan. Maka barang siapa yang (menjadikan) hijrahnya kepada Allah dan Rasul-Nya dan barang siapa yang menjadikan hijrahnya untuk mendapatkan faedah dunia atau untuk mengahwini seorang perempuan, hijrahnya adalah untuk apa yang dihijrahkan."

(Hadis Riwayat Bukhari dan Muslim)

Niat ini akan mempengaruhi keikhlasan tindakan seseorang. Niat yang ikhlas serta disusuli dengan perbuatan yang baik dikira sebagai amal ibadat yang akan mendapat ganjaran bukan sahaja di dunia tetapi juga di akhirat. Firman Allah yang bermaksud:

"Katakanlah: Sesungguhnya sembahyangku, ibadatku, dan matiku semuannya bagi Allah, Tuhan semesta alam."

(Surah al-An'ām 6: 162).

Sekiranya seseorang tidak ikhlas dalam melaksanakan sesuatu pekerjaan ia akan menjadi punca kepada berlakunya manipulasi dan mempolitikkan fungsi penilaian prestasi. Penilai perlu insaf setiap tindakan mereka akan dinilai di sisi Allah SWT. Perkara ini pernah diberi amaran oleh Allah SWT melalui firman-Nya yang bermaksud:

"Sesiapa yang melakukan kesalahan (kejahatan) sebesar atom pun akan dilihatNya"

(Surah al-Zalzalah 99: 8)

\section{Sifat-Sifat yang Perlu Dimiliki oleh Penilai}

Bagi berhadapan dengan masalah semasa melaksanakan penilaian prestasi dan kesan-kesan buruk akibat daripadanya, Islam telah mengenal pasti beberapa strategi yang perlu dihayati oleh setiap penilai. Antara strategi-strategi yang dimaksudkan adalah seperti berikut: 


\section{Mengutamakan Kesabaran}

Penilai perlu turut memanifestasikan sifat sabar mereka terhadap gelagat pekerja, pelanggan dan pihak-pihak lain yang terlibat dalam pelaksanaan penilaian prestasi 360 Darjah. Penilai yang sabar menerima segala cabaran dengan tenang, tidak mudah gelabah dan tahu bila, kenapa dan bagaimana sesuatu tindakan perlu diambil dengan penuh bijaksana. Semangat dan ketabahan yang ada pada mereka menunjukkan kewibawaan dalam menjalankan tugas yang telah diamanahkan. Penilai sedemikian juga tidak mudah hilang pedoman atau mencampakkan diri mereka ke lembah kekecewaan apabila berhadapan dengan kegagalan kerana kesabaran yang dimiliki bakal membimbing dan mendorong mereka untuk terus melakukan yang terbaik.

Di samping itu, mereka tidak mudah berpuas hati dengan pencapaian kerjanya walaupun diberi penghargaan atau pujian atau sanjungan. Sifat tidak berpuas hati dengan pencapaian semasa akan menyebabkan mereka terus berusaha untuk memastikan kemakmuran organisasi yang berterusan. Mereka perlu yakin bahawa kesabaran mereka menghadapi cabaran dan rintangan akan mendatangkan kesan yang baik untuk jangka masa dekat atau jangka masa yang panjang. Bagi mereka setiap kegagalan yang dilalui merupakan satu pengajaran yang sangat berharga.

\section{Mengamalkan Sikap Bekerjasama}

Masalah berkaitan dengan pelaksanaan penilaian prestasi Maklum Balas 360 Darjah boleh diminimumkan dengan adanya kerjasama antara pekerja, penilai dan pengurus atasan (Abuznaid, 2006). Bagi Tayeb (1997) kerjasama yang wujud akan meningkatkan semangat kerja berpasukan, mewujudkan suasana saling sokong menyokong dan boleh meningkatkan produktiviti organisasi. Kesedaran untuk terus saling bekerjasama hendaklah berdasarkan kepada semangat persaudaraan (ukhuwah) bertujuan untuk sama-sama meningkatkan kualiti organisasi. Kerjasama yang perlu diberikan hendaklah melangkaui warna kulit, bangsa, sempadan geografi, keturunan dan status. Allah SWT pernah menjelaskan melalui firman-Nya yang bermaksud:

"Dan tolong menolonglah kamu dalam mengerjakan kebajikan dan taqwa dan jangan tolong menolong dalam berbuat dosa dan kerosakan." 


\section{Berihsan}

Ihsan bermaksud melaksanakan tugas dengan cekap dan berkesan. Mereka yang memiliki sifat ihsan akan penuh yakin bahawa Allah SWT sentiasa memerhati kerja yang dilakukan (Yusof Al Qaradawi, 1985) sehingga menjurus mereka menyerahkan diri dalam memberi sepenuh perkhidmatan kepada Allah SWT (Syed Muhammad Naquib, 1978). Penilai yang memiliki sifat ini akan lebih bersedia untuk memaafkan kesilapan yang dilakukan oleh pekerja (Maududur Rahman \& Muhammad Al-Buraey, 1992).

Keihsanan yang dibuktikan hendaklah berdasarkan kepada keilmuan, kemahiran, pengalaman dan kemampuan yang dimiliki oleh penilaipenilai yang terlibat. Penilai-penilai yang menitik beratkan nilai keihsanan tidak akan melakukan aktiviti ini secara sambil lewa dan acuh tak acuh. Allah SWT telah menjanjikan ganjaran yang baik kepada mereka yang melakukan pekerjaan dengan baik, sempurna dan dengan penuh keihsanan. Firman-Nya yang bermaksud:

"Sesungguhnya Allah tidak menghilangkan pahala orangorang yang berusaha memperbaiki amalnya."

(Surah at-Tawbah 9: 120)

Di samping itu, bagi memastikan kecekapan dan keberkesanan penilai tidak sepatut bertindak secara ad hoc, gopoh dan tidak melihat secara menyeluruh kesan daripada tindakan dan keputusan yang telah diambil. Mereka perlu sedar kesilapan dalam memilih strategi akan menyebabkan organisasi menghadapi bebanan kewangan dan juga bukan kewangan.

\section{Sentiasa Amanah}

Amanah adalah prinsip akauntabiliti kepada Allah SWT. Bagi Ab Mumin dan Fadillah (2008) amanah perlu diterima sebagai mekanisme menghargai kepercayaan yang telah diberikan oleh seseorang yang perlu dilakukan dengan sebaik mungkin. Pandangan ini selari pendapat Mohd Asri dan Mohd Nor (2010) yang merujuk amanah sebagai perbuatan tidak melampau dalam urusan yang dipertanggungjawabkan ke atas seseorang. Mereka yakin segala usaha yang diambil untuk memakmurkannya merupakan satu ibadat kepada Allah SWT. (Kazmi \& Ahmad, 2006). 
Begitu juga dalam melaksanakan penilaian prestasi, penilai perlu menunaikan amanah ini sebagai satu tanggungjawab kepada pekerja untuk dilaksanakan dengan sebaik yang mungkin (Hanafi \& Sallam, 2006). Bagi Rashid, Mohd Yadman dan Salahudin (2008) pelaksanaan penilaian prestasi yang dilakukan dengan penuh amanah dilakukan dengan bersandarkan kepada fakta yang tepat. Mereka perlu mengelak daripada membuat keputusan yang dipengaruhi oleh kepentingan diri sendiri. Muhammad Nubli (2008) berpendapat kepentingan sifat amanah berkait rapat dengan pengagihan sumber organisasi. Justeru, penilai sebagai pemegang amanah tiada hak untuk memanipulasi sumber organisasi dengan menafikan hak yang perlu diberikan kepada pekerja. Mereka perlu akur pelaksanaan penilaian prestasi Maklum Balas 360 Darjah yang melibatkan persoalan dan masa depan pekerja perlu dilaksanakan dengan penuh amanah (Rashid, Mohd Yadman, \& Salahudin, 2008).

\section{Keterbukaan}

Penilai perlu sentiasa bersikap terbuka. Keterbukaan mereka akan menyebabkan mereka bersikap lebih sensitif, fleksibel, kreatif dan mempunyai perasaan ingin tahu yang tinggi. Pada masa yang sama mereka lebih bersedia untuk menerima teguran, cadangan dan berlapang dada apabila bersemuka dengan pelbagai pihak yang berkepentingan. Mereka juga akan lebih bersedia untuk menerima maklum balas daripada kumpulan sasaran. Sifat keterbukaan yang dimiliki akan menyebabkan pelbagai pihak lebih bersedia untuk menyuarakan pandangan kerana mereka tahu terdapatnya perasaan saling percaya mempercayai dalam kalangan mereka.

Sikap keterbukaan yang ada pada mereka akan dapat meningkatkan keberkesanan aliran maklumat kerana kesediaan mereka untuk berkomunikasi dengan kumpulan sasar yang berada dipelbagai peringkat dari yang serendah-rendahnya hinggalah ke peringkat yang setinggi-tingginya. Sikap sebegini sudah tentu dapat mengelakkan mereka daripada berasa selesa dengan pencapaian semasa serta mengutamakan status quo kerana sentiasa memperoleh input baru sama ada dalam bentuk cadangan atau kritikan. Mereka juga lebih proaktif terhadap perkembangan teknologi dan penciptaan baru. Keterbukaan akan memungkinkan mereka mempelajari sesuatu yang baru tanpa mengambil kira sumber dari mana datangnya kebenaran berkenaan. 


\section{Kesederhanaan}

Dalam konteks pelaksanaan penilaian prestasi Maklum Balas 360 Darjah, kesederhanaa adalah sikap penilai yang menolak keterlaluan sama ada dalam menetapkan sesuatu peraturan, sasaran dan ganjaran. Mengikut Yusof Al-Qaradawi (1984), Islam adalah manhaj yang sederhana dalam setiap perkara sama ada antara persepsi dan iktikad, ibadat dan cara melaksanakannya, pada akhlak dan cara hidup dan pada muamalat dan perundangan. Umat Islam merupakan umat yang menjadi teladan (qudwah) kerana keseimbangannya. Dengan memiliki sifat kesederhanaan akan mengelak penilai daripada mengambil tindakan yang melampau terhadap pekerja yang tidak disukai dengan memastikan mereka tidak membelakangkan kehidupan di akhirat (Mohd Nasir, 2005). Rasulullah SAW pernah bersabda yang bermaksud:

\section{"Jauhilah melampau dalam agama. Sesungguhnya rosaknya orang-orang sebelum kamu kerana melampau dalam agama."}

(Hadis Riwayat Ahmad)

Kesederhanaan juga melambangkan kecemerlangan penilai kerana kebolehan mereka untuk mengimbangkan keperluan dunia dan akhirat yang berteraskan keikhlasan yang akan memberikan erti dan kesan yang baik kepada pelbagai pihak (Mohd Fuad, 1985). Mereka tidak akan bersikap keterlaluan dalam membuat pertimbangan dan tindakan dengan memastikannya selari dengan ajaran Islam yang mahukan mereka sentiasa bersederhana.

\section{Bermuhasabah}

Islam menggariskan muhasabah sebagai asas kepada rukun Iman iaitu mengimani Yaum al-Hisab. Penilai semestinya melakukan aktiviti penilaian dengan penuh rasa tanggungjawab dan berwaspada tentang suatu hari di mana semua sahsiah dan tindak-tanduk akan dikira dan dihisab. Bagi Hassan al-Banna (1998) muhasabah merupakan suatu bentuk amalan kerohanian untuk mengubat jiwa dan ianya turut memberi implikasi positif kepada jasmani manusia. Menurut beliau jiwa manusia merupakan sumber sistem, fikiran, konsep dan pembentukan sahsiah. Amalan muhasabah perlu bagi mengukur tahap dan kesan pelaksanaan aktiviti penilaian ke atas individu serta organisasi. Dalam masa yang sama membantu penilai dalam menilai kekuatan, kelemahan, peluang dan ancaman. 
Penilai perlu membuat penilaian terhadap pelaksanaan tugas dan tanggungjawab secara berterusan. Dalam melaksanakan tugas ini, mereka hendaklah sentiasa bermuhasabah terhadap tindakan dan keputusan yang diambil serta sedar natijah daripadanya. Tujuan penilaian dibuat bukan untuk mencari kelemahan yang boleh menggagalkan organisasi sebaliknya bertujuan untuk membolehkan pekerja untuk terus memperteguhkan kekuatan.

Allah SWT menjanjikan kepada orang yang sentiasa berwaspada daripada melakukan perkara yang boleh mendatangkan kemurkaan AllahSWT. Mereka perlu sentiasa bermuhasabah diribagi memastikan mereka mendapat kecemerlangan di dunia dan di akhirat. Penilai yang sentiasa berwaspada dan prihatin terhadap urusan mereka akan beroleh kejayaan dan kemenangan.

\section{Keredaan Allah}

Sungguhpun pelaksanaan penilaian prestasi Maklum Balas 360 Darjah yang dilakukan adalah bertujuan mendapatkan keuntungan organisasi sama ada dalam bentuk kewangan atau bukan kewangan tetapi kegiatan ini juga merupakan alat untuk mencapai matlamat yang terunggul iaitu memperoleh keredaan Allah (marthatillah). Bagi penilai sedemikian, usaha untuk mendapatkan keredaan Allah SWT merupakan matlamat hakiki penglibatan mereka dalam pengurusan organisasi. Mereka akan sentiasa mempersoalkan tindakan dan keputusan sejauh mana akan mendekatkan diri atau menjauhkan diri daripada keredhaan Allah.

Di samping memperoleh keuntungan mereka perlu berusaha mengagihkan keuntungan yang diperoleh secara adil dengan pelbagai pihak yang berkepentingan. Keredaan yang diperoleh daripada Allah SWT akan memberi ruang kepada mereka untuk terus melipatgandakan usaha bagi memastikan berlakunya penambahbaikan dan kemajuan yang berterusan. Allah telah menjanjikan kejayaan berterusan kepada golongan yang sentiasa tunduk dan patuh kepada ajaran-Nya. Firman Allah SWT yang bermaksud:

"Sekiranya penduduk suatu negeri itu beriman dan bertaqwa, nescaya Kami akan membuka kepada mereka (pintu-pintu pengurniaan) yang melimpah-limpah berkatnya dari langit dan bumi." 


\section{Rumusan}

Islam telah menyediakan pendekatannya sendiri dalam pelaksanaan penilaian prestasi Maklum Balas 360 Darjah. Pendekatan yang disediakan adalah untuk memastikan pelaksanaan yang menyeluruh selari dengan syariat yang telah ditetapkan. Dalam Islam penilaian prestasi Maklum Balas 360 Darjah diterima sebagai mekanisme untuk menilai pencapaian setiap tugas dan tanggungjawab yang telah diamanahkan agar selari dengan tuntutan Islam. Yang paling utama, anggota yang menilai dan yang dinilai perlu memiliki ciriciri yang boleh membawa mereka ke arah memperoleh keredaan daripada Allah SWT.

Semasa melaksanakannya mereka akan meletakkan sepenuh keyakinan bahawa Islam merupakan agama yang paling kontemporari dan sesuai pada semua tempat, dalam pelbagai situasi, di sepanjang zaman serta mampu menyediakan jalan keluar terhadap pelbagai permasalahan yang berpunca daripada kelemahan manusia. Mereka perlu sedar natijah daripada pelaksanaan yang selari dengan ajaran Islam bakal membolehkan mereka memperoleh kejayaan hakiki yang bersifat holistik.

\section{Rujukan}

A. Qadir Audah. (1981). Islam di antara kejahilan umat dan kelesuan ulamak. Kuala Lumpur: IIFSO.

Abbas, J., Gibbs, M., \& Camp, R. (2000). Human resource strategy: The ten commandment perspective. The International Journal of Sociology and Social Policy, 20(5/6), 114-133.

Ab Mumin., Ab Ghani, \& Fadillah Mansor. (2008). Dimensi pengurusan Islam mengurus kerja dan mengurus modal insan. Kuala Lumpur: Penerbit Universiti Malaya.

Abu A'la Maududi, Sayyid. (1991). The Islamic movement: Dynamics of values, power and change. Khurram Murad (Ed.). Leicester, UK: The Islamic Foundation.

Abuznaid, S. (2006). Islam and management: What can be learned?

Thunderbird International Business Review, 48(1), 125-39.

Al-Bukhari. (1994). Sahih al-Bukhari. Beirut: Dar al-Fikr.

Al-Buraey, M. A. (2001). The Islamic model of administration:

Strategy, implementation and implications. Managerial Finance, 27(10/11), 5-24. 
Afzal-Ur-Rahman. (1994). Doktrin Ekonomi Islam (Jld.1) (Terj.). (Mustafa Kassim. Pentj.). Kuala Lumpur: Dewan Bahasa dan Pustaka.

Albright, M., \& Carr, C. (1997). 101 Biggest mistakes managers make and how to avoid them. United States of America: Prentice Hall Press.

Ali, A. (2005). Islamic perspectives on management and organization.

Edward Elgar: Cheltenham and Northampton, MA.

Ali Jarishah. (1990). Kehormatan hak-hak insan menurut Islam.

(Mohd Marzuki Shafie Pentj.). Kuala Lumpur: Dewan Bahasa dan Pustaka.

Ali Shari'ati. (1979). On the sociology of Islam. Berkeley: Mizan Press.

Mohd Asri Abdullah, \& Mohd Nor Mamat. (2010). Islam dan pengurusan: Menagani arus globalisasi. Shah Alam: UPENA.

Azman Che Omar. (2001). Pekerjaan di Malaysia dari perspektif Islam. Kuala Lumpur: Dewan Bahasa dan Pustaka.

Azzam Tamimi, \& John L. E. (2000). Islam and secularism in the Middle East. London: Hurst and Company.

Banks, G., \& Murphy, K. (1985). Toward narrowing the researchpractice gap in performance appraisal. Personnel Psychology, 38, 335-345.

Baron, J. N., \& Kreps, D. M. (1999). Strategic human resources: Frameworks for general managers. New York: John Wiley \& Sons.

Mohamed Barween. (2002). The fundamental human rights: An Islamic perspective. The International Journal of Human Rights, 6(1), 61-78.

Bilal Khan, Ayesha Farooq, \& Zareen Hussain, (2010). Human resource management: An Islamic perspective. Asia-Pacific Journal of Business Administration, 2(1), 17-34.

Comerford, H. (2002). Findings Report Respectful Workplace Project. Government of Newfoundland and Labrador, Mimeo.

Dacri, R. (2005). Unwanted, disliked, dishonest: Performance appraisals. Retrieved from http://business.mainetoday.com

Danial Zainal Abidin. (2003), Islam agama unik lagi unggul. Dlm. Danial Zainal Abidin. Empayar minda muslim: Modul tarbiah asas alat ketiga. Pahang: PTS Publication and Distributors.

Deondra, S. C. (2006). Human-resource professionals' perceptions of organizational politics as a function of experience, organizational size, and perceived independence. The Journal of Social Psychology, 146(6), 717-732.

Derven, M. G. (February, 1990). The paradox of performance appraisals. Personnel Journal, 69, 107-111. 
Hill, D. R. (1993). Islamic science and engineering. Edinburgh: University Press.

Duran, K. (1997). Leonard Swidler's draft of a global ethic: A Muslim perpective. Center for Global Ethics, Philadelphia, PA.

Edwards, M. (1989). Making performance appraisal meaningful and fair. Business, 17-24.

Edwards, M, \& Ewen, A. (1996). 360 feedback: The powerful new model for employee assessment and performance improvement. New York: America Management Association.

Endang Saifuddin Anshari. (1986). Wawasan Islam: Pokok-pokok fikiran tentang Islam dan ummatnya. Jakarta: CV. Rajawali.

Endot, S. (1995). The Islamisation process in Malaysia (Unpulished doctoral dissertation). University of Bradford.

Hanafi, M., \& Sallam, B. (2006). Perspectives on Islam and management. Working Paper No.141, International Islamic University, Kuala Lumpur.

Hassan al-Banna. (1998). Konsep pembahuruan masyarakat Islam. Kuala Lumpur: Thinker Liabrary.

Hassan Langgulung. (1998). Islamic education and human resource development in Moslem countries. Kesturi, 8(1), 1-18.

Ivancevich, J. (2001). Human resource management (8th ed.). Boston: McGraw-Hill.

Jamal A. Badawi. (2002). Islamic worldview: Prime motive for development. Humanomics, 18(3), 3-25.

Joni Tamkin Borhan. (2008). Pemikiran pembangunan ekonomi berteraskan Islam [Thoughts on Islamic-based economic development]. Jurnal Usuluddin, 27, 93-107.

Junaidah Hashim. (2009). Islamic revival in human resource management practices among selected Islamic organisations in Malaysia. International Journal of Islamic and Middle Eastern Finance and Management, 2(3), 251-287.

Kazmi, A., \& Ahmad, K. (2006). Management from Islamic perspective. Instructors' resource manual. Kuala Lumpur: International Islamic University.

Khaliq Ahmad. (2004). Choice of allocation norms and perceived fairness of Malaysian corporat management. International Journal of Commerce \& Management, 14(2), 15-32.

Khursid Ahmad. (1991). Kajian dalam ekonomi Islam. Kuala Lumpur: Dewan Bahasa dan Pustaka.

King, J. E., \& Williamson, I. O. (2005). Workplace religious expression, religiosity, and job satisfaction: Clarifying a relationship. Journal of Management, Spirituality, and Religion, 2(2), 173-198. 
Latham, G., \& Wexley, K. (1994). Increasing productivity through performance appraisal (2nd ed.). Reading: Addison-Wesley Publishing.

Mansor, N., \& Ali, J. M. (1998). An exploratory study of organizational flexibility in Malaysia: A research note. International Journal of Human Resource Management, 9(3), 506-515.

Maududur Rahman, \& Muhammad Al-Buraey. (1992). An Islamic prespective of organizational controls and performance evaluation. The American Journal of Islamic Social Sciences, 9(4), 499-514.

Mohd Affandi Hassan. (1992). The tawhidic approach in management and public administration. Kuala Lumpur: National Institute of Public Administration.

Mohd Fuad Mohd Lip. (1985, April). Keikhlasan dalam setiap kehidupan. Al-Islam, hlm. 16-18.

Mohd. Nasir Omar. (2005). Akhlak dan kaunseling Islam. Kuala Lumpur: Utusan Publications and Distributors.

Mondy, R. W. (2010). Human resource management (11th ed.). New Jersey: Pearson Education.

Monir Toyeb. (1997). Islamic revival in Asia and human resourse management. Employee Relations, 19(4/5), 352-365.

Moses, J., Hollenbeck, G., \& Sorcher, M. (1993). Other people's expectations. Human Resource Management, 32, 283-297.

Muhammad Nubli Abdul Wahab. (2008). Kecemerlangan pengurusan organisasi dalam Islam. Pahang: Penerbit Universiti Malaysia.

Muhammad Syukri Salleh. (2001). Konsep dan perkaedahan pengurusan pembangunan berteraskan Islam. Pemikir, Bil. 26 (Oktober-Disember), 1- 47.

. (2002). Pembangunan berteraskan Islam. Kuala Lumpur: Utusan Publications \& Distributors.

. (2003). 7 Prinsip pembangunan berteraskan Islam. Kuala Lumpur: Zebra Editions.

Mustaq Ahmad. (2001). Etika bisnis dalam Islam. Jakarta Timur: Pustaka Al-Kautsar.

Napier, N., \& Latham, G. (1986). Outcome expectancies of people who conduct performance appraisals. Personnel Psychology, 39, 827-837.

O'Reilly, Brian. (1994). 360 feedback can change your life. Fortune, 130(8), 93-100.

Rahmad Sukor Ab. Samad \& Gooi Ai Wei. (2005). Hubungan antara iklim sekolah dengan kepuasan kerja guru sekolah menengah di Wilayah Persekutuan. Jurnal Pendidikan. Fakulti Pendidikan: Universiti Malaya. 
Rashid Muhamad Mohd Yadman Sarwan, \& Salahudin Suyurno. (2008). Pengurusan Islam: Teori dan praktis. Shah Alam: UPENA. Reave, L. (2005). Spiritual values and practices related to leadership effectiveness. Leadership Quarterly, 16(5), 255-287.

Robbins, S. P. (2005). Organizational behavior: Concepts, controversies, and applications. Englewood Cliffs, NJ: Prentice Hall.

Roberts, G. (1998). Perpectives on enduring and emerging issues in performance appraisal. Public Personnel Management, 27(3), 301-320.

Rudner, L. M. (1992). Reducing errors due to the use of judges. Practical Assessment, Research E Evaluation, 7(26), 241-271.

Sayyid Qutb. (1983). Social justice in Islam. Kuala Lumpur: The Open Press.

Sidi Gazalba. (1986). Masyarakat Islam: Pengantar sosiologi dan sosiolgrafi. Kuala Lumpur: Pustaka Antara.

Surtahman Kastin Hasan. (1993). Ekonomi Islam: Dasar dan amalan. Kuala Lumpur: Dewan Bahasa dan Pustaka.

Syed Muhammad Al-Naquib Al-Attas. (1977). Islam: Faham agama dan asas akhlak. Kuala Lumpur: Angkatan Belia Islam Malaysia. . (1978). Islam and secularism. Kuala Lumpur: Muslim Youth Movement of Malaysia. . (2005). Islamic philosophy: An introduction. ISTAC, Kuala Lumpur. Journal of Islamic Philosophy, 1,11- 43.

Tafsir Pimpinan Ar-Rahman. (n.d). Kuala Lumpur: Darulfikir.

Tayeb, M. (1997). Islamic revival in Asia and human resource management. Employee Realations, 19(4), 352-364.

Taylor, M., Tracy, B., Renard, K., Harrison, J., \& Carroll, J. (1995).

Due process in performance appraisal: A quasi-experiment in procedural justice. Administrative Science Querterly, 40(3), 495-515.

Thach, E. C. (2002). The impact of executive coaching and 360 feedback on leadership effectiveness. Leadership $\mathcal{E}$ Organization Development Journal, 23(4), 205.

Wan Liz Osman Wan Omar. (1996). Pengurusan Islam abad ke-21: Revolusi pengurusan untuk keunggulan sektor awam dan korporat. Kuala Lumpur: Utusan Publications \& Distributions.

Weaver, G., \& Agle, B. (2002). Religiosity and ethical behaviour in organizations: A symbolic interactionist perspective. Academy of Management Review, 27(1), 77-97.

Wiese, D. S., \& Buckley, M. R. (1998). The evolution of performance appraisal process. Journal of Management History, 4(3), 233-249. Wimer, S. (2002). The dark side of 360-degree feedback. Training and Development, September, 37-42. 
Yousef, D. A. (2000). Organizational commitment: A mediator of the relationships behavior with job satisfaction and performance in a non-western country. Journal of managerial psychology, 15(1), 6-24.

Yousef, D. A. (2001). Islamic work ethic-a moderator between organizational commitment and job satisfaction in a crosscultural contex. Personnel Review, 30(2), 152-169.

Yusof Ali. (1983). The holy Quran: Translation and commentary. Maryland: Amana Corporation.

Yusof Al-Qaradawi. (1984). Kebangunan Islam di antara tantangan dan ekstrimisme. Petaling Jaya: Angkatan Belia Islam.

Yusof Al-Qaradawi. (1985). Iman dan kehidupan. Shah Alam: Dewan Pustaka Fajar.

Yusof Al-Qaradawi. (2000). Ciri-ciri masyarakat Islam yang kita idamkan. (Ustaz Mohammad Zaini Yahaya Pentj.). Kuala Lumpur: Penerbitan Seribu Dinar.

Zahid Parvez., \& Pervaiz Ahmed. (2004). An Islamic perspective on the lack of social responsibility in business organization. Working Paper series no: WP005/04, Management Research Centre, Wolverhampton University Business School.

Zivnuska, S., Kacmar, K. M., Witt, L. A., Carlson, D. S., \& Bratton, V. K. (2004). Interactive effects of impression management and organizational politics on job performance. Journal of Organizational Behavior, 25, 627-640. 


\section{NOTES TO CONTRIBUTORS}

\section{MANUSCRIPTS}

Manuscripts should be written as accurately as possible and should be typed in double-spacing on one side of an A4 size paper with margins of at least $25 \mathrm{~mm}$. Each manuscript should not exceed 25 pages. Two copies of the paper should be submitted together with a CD containing the file in MSWord compatible to IBM or Macintosh machines. Authors should identify the software in the cover letter when submitting manuscripts.

Since manuscripts are reviewed anonymously, the author's name and affiliation should be supplied only on a cover sheet and authors should avoid any identifying text references. The title of the manuscript should appear on the cover sheet at the top of the first page. Manuscripts will be reviewed by a panel of referees. Comments will be made available to contributors without disclosing the referees' names.

\section{COVER LETTER}

Manuscripts should be accompanied by a cover letter stating that the material has not been published, and not under consideration for publication elsewhere.

\section{ABSTRACT}

The abstract should be brief, self-contained and explicit, and should not exceed 200 words. Contributor who submits a manuscript in Bahasa Melayu is required to submit an extended abstract in English not exceeding 300 words.

\section{REFERENCES}

References should be carefully checked. The references are to be cited in the text in the author-date format (APA style e.g. Armstrong \& Overton, 1977; Salma \& Mohd. Makzan,1996). A reference list only of works cited, should be provided at the end of the text arranged in alphabetical order. Examples of the format for journals and books are as follows:

Armstrong, J. S., \& Overton, T. S. (1977). Estimating non-response bias in mail surveys. Journal of Marketing Research, 14, 396-402.

Salma Ishak., \& Mohd. Makzan Musa. (1996). Attitudes of police personnel towards their job. ANALISIS, 4 (1), 13-31. 
Kimberly, J. R., Norling, F., \& Weiss, J. A. (1983). Pondering the performance puzzle. In R. H., Hall \& R. E., Quinn (Eds.), Organizational theory and public policy (249-264). Beverly Hills: Sage.

Van Horne, J. C. (1992). Financial management and policy. Englewood Cliffs, New Jersey: Prentice Hall.

\title{
END NOTES
}

Footnotes should not be used. Endnotes should be used instead.

\section{ABBREVIATION}

Full names of agencies should be used in the first citation in any article. Accepted abbreviations or acronyms may be used for subsequent citations.

\section{TABLES}

Tables should be numbered with Arabic numerals. Title and column headings should be brief.

\section{ILLUSTRATIONS}

Photographs, if any, should be large, clear, glossy prints, showing high-contrast.

\section{CONTRIBUTORS}

Contributors must provide their full names, fax numbers and full addresses. A contributor will receive a complimentary copy of the issue in which his/her article appeared and 10 off-prints.

\section{SUBMISSION OF MANUSCRIPTS}

Manuscripts and enquires should be directed to:

\author{
Chief Editor \\ International Journal of Management Studies \\ UUM Press \\ Universiti Utara Malaysia \\ 06010 UUM Sintok \\ Kedah, Malaysia
}

